
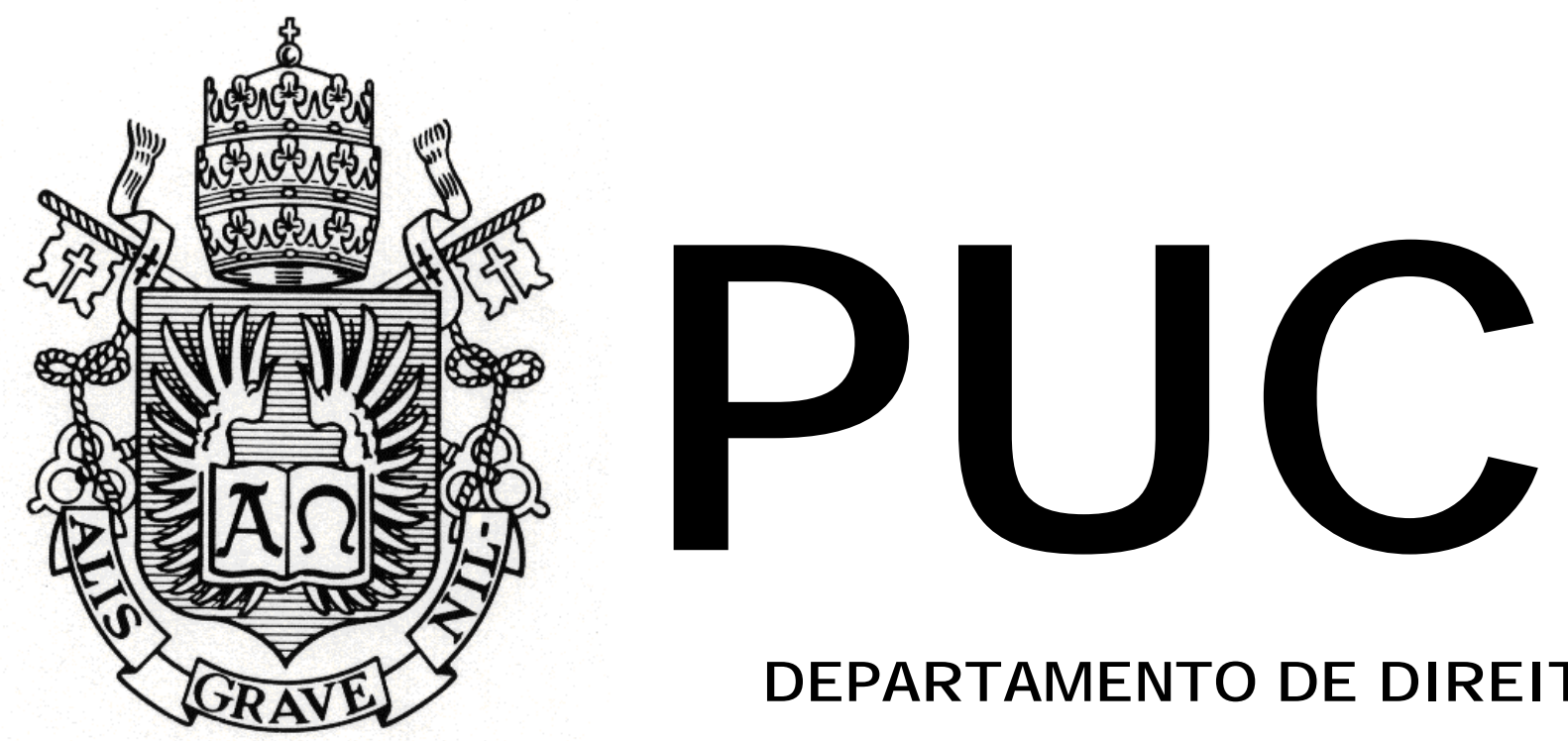

DEPARTAMENTO DE DIREITO

\title{
PADRÕES DE ACESSO À JUSTIÇA DO SISTEMA INTERAMERICANO DE PROTEÇÃO DOS DIREITOS HUMANOS PARA MULHERES VITTIMAS DE VIOLÊNCIA
}

por

MARIA J. DE NEGREIROS

ORIENTADOR(A): Márcia Nina Bernardes

2010.2

PONTIFÍCIA UNIVERSIDADE CATÓLICA DO RIO DE JANEIRO RUA MARQUÊS DE SÃO VICENTE, 225 - CEP 22453-900 RIO DE JANEIRO - BRASIL 


\title{
PADRÕEs de ACESSO À JUSTIÇA DO SISTEMA INTERAMERICANO DE PROTEÇÃO DOS DIREITOS HUMANOS PARA MULHERES VÍTIMAS DE VIOLÊNCIA
}

\author{
por \\ Maria J. de Negreiros
}

Monografia apresentada ao Departamento de Direito da Pontifícia Universidade Católica do Rio de Janeiro (PUC-Rio) para a obtenção do Título de Bacharel em Direito.

Orientador(a): Márcia Nina Bernardes 
À minha mãe,

meu maior exemplo, pelo amor incondicional. 


\section{Agradecimentos}

A Deus, obrigada por ter guiado os meus passos durante toda a trajetória acadêmica.

Aos meus pais, agradeço por todo amor e apoio dedicados a mim.

À minha família, agradeço por sempre ter acreditado e torcido pelo meu sucesso.

Às minhas amigas de escola, obrigada por terem me ensinado o verdadeiro significado da amizade.

Às amigas e amigos da faculdade, agradeço pelo amor e carinho construídos durante o curso e pelos momentos inesquecíveis compartilhados.

Às demais amigas e amigos que têm uma importância especial na minha vida, agradeço por tudo.

À minha querida orientadora Márcia Nina Bernardes, a quem devo um agradecimento especial pelo papel determinante em toda a minha trajetória acadêmica. Obrigada pelo carinho, pelo exemplo, pela paciência, pelas orientações e ensinamentos e por todas as oportunidades que foram essenciais para o meu crescimento pessoal e acadêmico. Dedico a ela, todo o meu carinho e a minha eterna admiração.

Ao grupo de gênero, para sempre formado pela nossa professora Márcia Nina, pelas minhas queridas amigas Adriana, Joanna, Marina, Thamar, Maria Fernanda, Carolina e Silje e pelo meu querido amigo Gabriel. Devo 
ao grupo todo o resultado deste trabalho. Obrigada por terem dado outro sentido ao meu curso, por todos os nossos prazerosos encontros e debates, por todo o aprendizado, pela amizade e pela paixão compartilhada em torno da luta pela conquista dos direitos das mulheres.

A todas as professoras, alunas e alunos que fazem ou fizeram parte do Núcleo de Direitos Humanos do Departamento de Direito da PUC-Rio, Carolina Campos Melo, Rachel Herdy, Bethânia Assy, Andrea, Fábio, Tete, Luiza, Pilar, Lele e Isabella, obrigada por todos os grandes momentos compartilhados em torno do amor pelos direitos humanos.

Às queridas Andrea e Luiza, muito obrigada pelo apoio especial, sem o qual o trabalho não teria sido o mesmo.

A todos, muito obrigada. 


\section{Resumo}

O presente trabalho monográfico tem como objetivo analisar os padrões de acesso à justiça para mulheres vítimas de violência desenvolvidos no âmbito do Sistema Interamericano de Direitos Humanos. Nesse sentido, buscar-se-á demonstrar os inúmeros obstáculos encontrados por mulheres vítimas de violência para que seja garantido o seu direito ao acesso efetivo aos mecanismos judiciais disponíveis e para que os Estados cumpram com a sua obrigação internacional de agir com devida diligência para prevenir, investigar, processar e reparar os atos de violência contra a mulher. Assim, iniciaremos o trabalho com a análise do âmbito normativo e do âmbito de atuação dos órgãos do Sistema Interamericano no que tange à defesa dos direitos da mulher a uma vida livre de violência e à garantia deste direito através do acesso efetivo às garantias judiciais. Posteriormente, trataremos propriamente do tema acesso à justiça, abordando as principais deficiências e obstáculos para que os Estados cumpram com a sua obrigação de devida diligência e para que as mulheres vítimas de violência tenham acesso às garantias e proteções judiciais. Por último, faremos uma análise detalhada do caso González e Outras vs. México ("Campo Algodonero"), demonstrando suas especificidades e sua relevância para o tema abordado.

\section{Palavras- Chave}

Discriminação e violência baseadas em gênero - Acesso à justiça Obrigação de devida diligência - Sistema Interamericano de Direitos Humanos - Corte Interamericana de Direitos Humanos - caso González e Outras vs. México ("Campo Algodonero"). 


\section{Sumário}

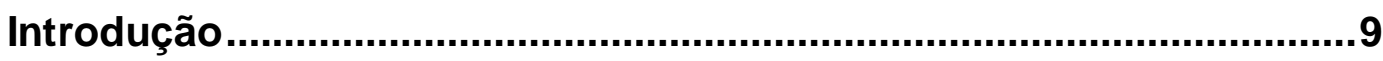

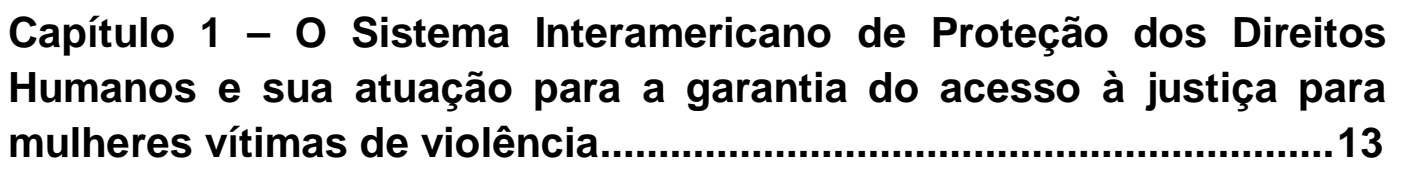

1.1. Âmbito normativo do Sistema Interamericano de Proteção dos Direitos Humanos para garantia do acesso à justiça para mulheres vítimas de violência

1.1.1. Convenção Americana sobre Direitos Humanos (Pacto de San José da Costa Rica).

1.1.2 Convenção Interamericana para Prevenir, Punir e Erradicar a Violência contra a Mulher (Convenção de Belém do Pará)

1.2. Competência dos órgãos do Sistema Interamericano na luta contra a discriminação de gênero.

1.2.1 Comissão Interamericana de Direitos Humanos e a Relatoria Especial sobre os Direitos da Mulher. 26

1.2.2. Corte Interamericana de Direitos Humanos .............................................28

2.1. Discriminação e violência baseadas em gênero..........................................31

2.2. Discriminação de gênero e acesso à justiça: a obrigação de devida diligência e os obstáculos enfrentados por mulheres vítimas de violência........40

a) $\mathrm{O}$ acesso à proteção judicial e a obrigação de devida diligência ...............40

b) Obstáculos para acesso à justiça: ineficácia e impunidade nos casos de violência contra as mulheres ..................................................................... 45

b.1) Deficiências na fase investigatória ........................................................4 4

b.2) Deficiências no trâmite judicial ................................................................54

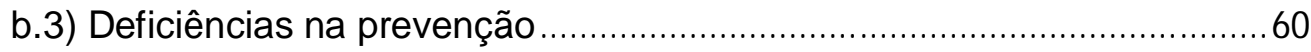

c) Ineficácia na formulação, aplicação e interpretação das leis ......................65

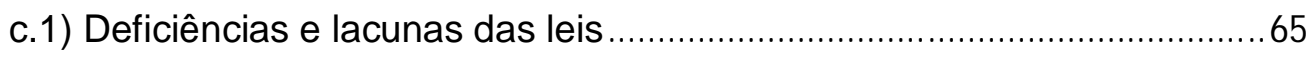

c.2) Ineficácia na aplicação e interpretação das leis......................................66 
Capítulo 3. O caso González e outras vs. México ("Caso Campo Algodonero") e a análise da jurisprudência da Corte Interamericana

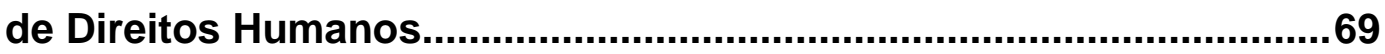

3.1 O caso González e outras vs. México (“Campo Algodonero")......................70

3.1.1. Apresentação do caso: fatos e demanda ……………………….........71

3.1.2 Contexto do caso - A violência estrutural e a discriminação de gênero na Ciudad Juárez ……………………..............................................

3.1.3 Considerações da Corte Interamericana de Direitos Humanos acerca do caso

3.1.4 Análise da sentença do caso González e Outras ("Campo Algodonero") Vs. México.

3.2 A jurisprudência da Corte Interamericana de Direitos Humanos e o reconhecimento da violência baseada em gênero 85

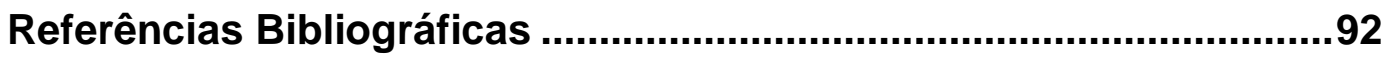




\section{Lista de Abreviações}

SIDH Sistema Interamericano de Proteção aos Direitos Humanos

Corte IDH Corte Interamericana de Direitos Humanos

Corte EDH Corte Européia de Direitos Humanos

CADH Convenção Americana de Direitos Humanos

Convenção Convenção Interamericana para Prevenir, Punir e Erradicar de Belém do a Violência contra a Mulher

Pará

CIDH Comissão Interamericana de Direitos Humanos

CIM Comissão Interamericana de Mulheres

OEA Organização dos Estados Americanos

ONU Organização das Nações Unidas

MESECVI Mecanismo de Seguimento da Convenção Interamericana para Prevenir, Punir e Erradicar a Violência contra a Mulher 


\section{Introdução}

$\mathrm{O}$ acesso à justiça foi estabelecido pelo Sistema Interamericano de Proteção dos Direitos Humanos (doravante SIDH ou Sistema Interamericano) como um dos principais caminhos para garantia dos direitos humanos dos indivíduos. A Comissão Interamericana de Direitos Humanos (doravante CIDH ou "Comissão Interamericana") começou a dar atenção especial para certos grupos sociais que são relegados a situações de desigualdade e exclusão e que, portanto, têm negado o seu direito ao acesso amplo e efetivo à justiça, como as mulheres. ${ }^{1}$ Nesse sentido, a Comissão Interamericana e a Relatoria Especial dos Direitos da Mulher têm se dedicado de forma prioritária à análise dos obstáculos enfrentados pelas mulheres para alcançarem o efetivo acesso aos sistemas de justiça, especialmente aquelas mulheres vítimas de violência e outras formas de discriminação baseadas em gênero. ${ }^{2}$ Apesar do consenso em torno da ideia de que a violência e a discriminação contra mulher são graves violações de direitos humanos que devem ser tratadas como desafios prioritários pelos Estados, ainda existe uma grande lacuna entre o reconhecimento da gravidade do problema e a qualidade da resposta judicial oferecida às mulheres vítimas de violência baseada em gênero. Não basta somente que os mecanismos judiciais estejam disponíveis e previstos legalmente, mas é necessário que eles sejam efetivos e aptos a responder os atos de violação perpetrados contra as mulheres. ${ }^{3}$

As mulheres vítimas de violência enfrentam diversas dificuldades para que tenham acesso às principais garantias, recursos e proteções judiciais, permitindo que essas violações permaneçam impunes. As deficiências na resposta judicial demonstram que os Estados não têm

\footnotetext{
${ }^{1} \mathrm{CIDH}$, Relatório sobre Acesso à Justiça para Mulheres Vítimas de Violência nas Américas, OEA/Ser.L/V//II, 20 Janeiro, 2007. Capítulo I. p.15. para. 81

${ }^{2}$ CIDH, Informe Anual, 2006. Capítulo II, para. 56-57.

${ }^{3}$ CIDH, Informe Anual, 2006. Capítulo II, para. 58.
} 
cumprido com a sua obrigação de atuar com a devida diligência para prevenir, investigar, punir e reparar a violência baseada em gênero. Ao contrário, a violência e a discriminação se demonstram como práticas aceitas pela administração da justiça, que as compreendem como questões não prioritárias, que podem ser resolvidas sem a ingerência do Estado, ou as legitimam a partir de concepções discriminatórias dos papéis que as mulheres representam em sociedade, criando a atmosfera de aceitabilidade e impunidade dessas práticas. ${ }^{4}$

As falhas dos sistemas da justiça de quase todos os Estados do continente se encontram, principalmente, na fase das investigações e na atuação para prevenção dos atos de violência, como demonstrado nos principais casos encaminhados para Comissão Interamericana e para Corte Interamericana de Direitos Humanos (doravante Corte IDH ou "Corte Interamericana"). As irregularidades, no entanto, se manifestam também na fase de processamento e punição desses crimes, criando um sentimento de insegurança e descrédito nas mulheres em relação à efetividade dos mecanismos judiciais disponíveis. As dificuldades se ampliam quando as mulheres reúnem outras condições, além do fator gênero, como classe social, idade ou origem étnica, que as relegam a uma posição de maior vulnerabilidade em relação à violência sofrida e criam mais obstáculos para que o acesso efetivo à justiça seja alcançado. ${ }^{5}$

O presente trabalho busca, portanto, demonstrar os padrões de acesso à justiça desenvolvidos pelo Sistema Interamericano de Proteção dos Direitos Humanos para mulheres vítimas de violência. Nesse sentido, realizou-se um estudo dos principais relatórios temáticos produzidos pela CIDH e pela sua Relatoria Especial dos Direitos da Mulher, bem como dos principais casos encaminhados à $\mathrm{CIDH}$ e à Corte IDH acerca do tema da

\footnotetext{
${ }^{4} \mathrm{CIDH}$, Relatoria Especial sobre os Direitos da Mulher. Relatório sobre Acesso à Justiça para Mulheres Vítimas de Violência nas Américas, OEA/Ser.L/V//II, 20 Janeiro, 2007. Capítulo I. pp. 17

${ }^{5}$ CIDH, Relatoria Especial sobre os Direitos da Mulher. Relatório sobre Acesso à Justiça para Mulheres Vítimas de Violência nas Américas, OEA/Ser.L/V//II, 20 Janeiro, 2007. Capítulo I. pp. 20.
} 
violência baseada em gênero e dos obstáculos encontrados pelas mulheres vítimas para que o acesso de facto à justiça seja alcançado.

Sendo assim, o trabalho será organizado em três capítulos. No primeiro capítulo, será apresentado o âmbito normativo e a competência dos principais órgãos do Sistema Interamericano no que se refere à proteção das mulheres contra a discriminação e a violência baseada em gênero e a garantia do direito das mulheres vítimas ao acesso à justiça. Nesse sentido, primeiramente, serão analisados os artigos relevantes dos principais instrumentos normativos que garantam o direito das mulheres a uma vida livre de violência e o seu direito ao acesso efetivo à justiça, a Convenção Americana de Direitos Humanos e a Convenção Para Prevenir, Punir e Erradicar a Violência contra a Mulher (Convenção de Belém do Pará). No que se refere ao âmbito de atuação dos órgãos do Sistema Interamericano, será feita uma apresentação da Comissão Interamericana e da sua Relatoria Especial sobre os Direitos das Mulheres, bem como da Corte Interamericana de Direitos Humanos, falando brevemente da atuação de cada um dos órgãos, que será especificamente desenvolvida nos capítulos seguintes com a análise dos principais casos tramitados no âmbito de cada um dos órgãos acerca do tema.

O segundo capítulo iniciará o desenvolvimento do objeto principal do trabalho, qual seja a análise dos padrões desenvolvidos pelo Sistema Interamericano para garantir que as mulheres vítimas de violência tenham pleno acesso aos mecanismos judiciais disponíveis e para que, portanto, os Estados atuem com devida diligência para prevenir, investigar, punir e reparar os atos de violência perpetrados. Para isso, analisaremos os padrões desenvolvidos pelo Sistema Interamericano através da análise dos relatórios temáticos produzidos pela CIDH e pela Relatoria Especial dos Direitos da Mulher, e através da análise dos principais casos encaminhados à CIDH que tenham relevância para cada um dos pontos abordados. 
O último capítulo tratará especificamente do caso González e Outras vs. México 6 ("Campo Algodonero") julgado pela Corte IDH em 2009 e da jurisprudência da Corte IDH acerca nos temas relacionados à discriminação e violência baseadas em gênero. Neste capítulo, iremos realizar a apresentação da demanda, os fatos relevantes e as consideração da Corte IDH acerca do caso. A partir da análise da sentença do caso, será feita uma análise da jurisprudência da Corte IDH, ressaltando o seu desenvolvimento acerca da interpretação dos casos de violência, discriminação de gênero e acesso à justiça.

\footnotetext{
${ }^{6}$ CORTE IDH, Caso González y Otras (“Campo Algodonero”) vs. México. Sentença de 16 de
} novembro de 2009. 


\section{Capítulo 1 - 0 Sistema Interamericano de Proteção dos Direitos Humanos e sua atuação para a garantia do acesso à justiça para mulheres vítimas de violência}

Paralelamente aos mecanismos do Sistema ONU de Proteção dos Direitos Humanos, outros instrumentos internacionais integrantes de sistemas regionais passaram a ampliar e fortalecer a proteção e garantia dos direitos humanos dos indivíduos, como os instrumentos que integram o Sistema Interamericano de Direitos Humanos, do qual o Brasil faz parte. No que se refere às questões relacionadas à discriminação de gênero, enquanto no âmbito do Sistema ONU, grupos de mulheres podem contar com o aparato da Convenção para Eliminação de Todas as Formas de Discriminação contra a Mulher $(\mathrm{CEDAW})^{7}$, no âmbito do Sistema Interamericano de Proteção dos Direitos Humanos, além da Convenção Americana sobre Direitos Humanos (doravante CADH ou Pacto de San José da Costa Rica), a Convenção para Prevenir, Punir e Erradicar a Violência contra a Mulher (doravante Convenção de Belém do Pará) representa uma importante ampliação na proteção internacional dos direitos das mulheres vítimas de violência.

\section{1. Âmbito normativo do Sistema Interamericano de Proteção dos Direitos Humanos para garantia do acesso à justiça para mulheres vítimas de violência}

O Sistema Interamericano de Proteção dos Direitos Humanos possui como uma de suas premissas de atuação o princípio de que o efetivo acesso à justiça é a primeira linha de defesa para proteção dos direitos humanos

\footnotetext{
7 Sob influência da proclamação do ano de 1975 como o Ano Internacional da Mulher, e da realização da primeira Conferência Mundial sobre a Mulher, no México em 1979, a Nações Unidas aprovaram a Convenção Sobre a Eliminação de Todas as Formas de Discriminação contra a Mulher (CEDAW), que foi o documento base para o surgimento de outros instrumentos internacionais direcionados a eliminação da discriminação contra a mulher. O Brasil ratificou a Convenção, em 1984 e ratificou o seu Protocolo Facultativo, em 2002. O Protocolo Facultativo à Convenção CEDAW amplia a competência do Comitê CEDAW, órgão de monitoramento da CEDAW, permitindo o envio de comunicações por indivíduos ou grupos de indivíduos que aleguem a ocorrência de violações a quaisquer direitos previstos na Convenção.
} 
básicos, o que inclui o direito das mulheres vítimas de violência. Para fins da análise do acesso à justiça para mulheres vítimas de violência, o âmbito normativo do Sistema Interamericano é composto por três instrumentos relevantes: a Declaração Americana dos Direitos e Deveres do Homem ${ }^{8}$, em seu artigo XVIII ${ }^{9}$, a Convenção Americana de Direitos Humanos (Pacto de San José da Costa Rica), em seus artigos $8^{\circ}$ e 25, e a Convenção Americana para Prevenir, Punir e Erradicar a Violência contra Mulher (Convenção de Belém do Pará), em seu artigo $7^{\circ}$.

Em casos de violência contra a mulher as obrigações gerais estabelecidas nos artigos $8^{\circ}$ e 25 da $\mathrm{CADH}$ se complementam e se reforçam com as obrigações derivadas do artigo $7^{\circ}$ da Convenção de Belém do Pará. Estes instrumentos defendem o direito das mulheres a remédios judiciais simples e efetivos que possam protegê-las contra os atos de violência perpetrados contra elas, além de estabelecerem a obrigação dos EstadosPartes de agirem com devida diligência para prevenir, processar, punir e reparar a violência baseada em gênero.

No presente trabalho, portanto, iremos nos concentrar na análise da Convenção Americana e da Convenção de Belém do Pará. Primeiramente, iremos fazer um breve panorama da Convenção Americana, para depois analisarmos os artigos do documento relativos ao direito de acesso à justiça. Posteriormente, dedicaremo-nos à apresentação mais detalhada da Convenção de Belém do Pará, instrumento que trata especificamente da

\footnotetext{
${ }^{8}$ A Declaração Americana de Direitos e Deveres do Homem, adotada em abril de 1948, na nona Conferência Internacional Americana realizada em Bogotá (Colômbia), oito meses antes da Declaração Universal de Direitos Humanos (10 de dezembro de 1948), demonstrou o compromisso da região com a proteção internacional dos direitos humanos e preparou o caminho para a Convenção Americana sobre Direitos Humanos, adotada em 1969. Disponível em: http://www.oas.org/pt/sobre/nossa_historia.asp. Acesso em 11.10.10. A Declaração Americana de Direitos e Deveres do Homem foi responsável pela formação da base normativa central para a proteção dos direitos humanos no âmbito americano no período que antecede a adoção da Convenção Americana, trazendo como principais contribuições, dentre outras: uma visão integral dos Direitos Humanos (civis, políticos, econômicos, sociais e culturais); e a constituição da base normativa vis-à-vis Estados não-Partes na Convenção Americana.

${ }^{9} \mathrm{O}$ artigo XVIII da Declaração Americana de Direitos e Deveres do Homem estabelece que: "Toda pessoa pode recorrer aos tribunais para fazer respeitar os seus direitos. Deve poder contar, outrossim, com processo simples e breve, mediante o qual a justiça a proteja contra atos de autoridade que violem, em seu prejuízo, quaisquer dos direitos fundamentais consagrados constitucionalmente."
} 
temática da violência baseada em gênero, procurando também dar maior ênfase às obrigações dos Estados-Partes de atuarem positivamente para garantir o acesso à justiça para as mulheres vítimas de violência.

\subsubsection{Convenção Americana sobre Direitos Humanos (Pacto de San José da Costa Rica)}

A institucionalização convencional do Sistema Interamericano de Proteção dos Direitos Humanos ocorreu com a criação da Convenção Americana sobre Direitos Humanos, ou Pacto de San José da Costa Rica, em 1969. ${ }^{10}$ A Convenção, que entrou em vigor em 1978, é o principal instrumento normativo do sistema, podendo ser aderida somente pelos Estados membros da Organização dos Estados Americanos (OEA). Além de acrescentar outras atribuições à Comissão Interamericana de Direitos Humanos $^{11}$, criada por força da OEA, e de estabelecer a Corte Interamericana de Direitos Humanos, a Convenção Americana reconhece um rol amplo de deveres civis e políticos, embora não enuncie de forma específica direitos sociais, culturais e econômicos, limitando-se a estabelecer que os Estados alcancem a plena realização desses direitos mediante a adoção de medidas efetivas. Estes direitos serão enunciados no Protocolo Adicional à Convenção, conhecido como Protocolo de San Salvador, criado em 1988, entrando em vigor somente em 1999. Também de acordo com a Convenção, os Estados possuem uma dupla obrigação: uma obrigação negativa, que consiste no dever de respeitar os direitos previstos na Convenção, e uma obrigação positiva, de garantia, que consiste no dever de adotar medidas necessárias e efetivas para assegurar o livre e pleno exercício desses direitos. ${ }^{12}$

\footnotetext{
${ }^{10}$ TRINDADE, Antônio A. Tratado de direito Internacional dos Direitos Humanos. Vol. III. $1^{\text {a ed. }}$ Porto Alegre: Sergio Antonio Fabris Editor, 2003. pp. 45.

${ }^{11}$ A CIDH mantém poderes adicionais anteriores à Convenção e que não decorrem diretamente dela, dentre eles, o de processar petições individuais relativas a Estados que ainda não são parte da Convenção.

12 PIOVESAN, Flávia. Direitos Humanos e o Direito Internacional Constitucional. Editora Saraiva, São Paulo. $7^{\text {a }}$ Edição, 2007. pp. 227-229.
} 
Os artigos $8^{\circ}$ e 25 da Convenção Americana são os dispositivos que tratam especificamente do tema acesso à justiça, objeto de análise no presente trabalho. Os artigos prevêem que qualquer pessoa tem o direito a um processo justo, com as devidas garantias e com o fornecimento de recursos judiciais efetivos. Estes direitos constituem um dos pilares fundamentais de uma sociedade democrática, na medida em que garante o respeito e a garantia aos direitos reconhecidos na Convenção. ${ }^{13} \mathrm{~A}$ proteção desses direitos é reforçada pela obrigação erga omnes dos Estados-Partes, prevista no artigo 1.1 da Convenção, de garantir os direitos e deveres previstos na Convenção Americana. ${ }^{14}$

\section{"Artigo 8: Garantias Judiciais}

1. Toda pessoa tem direito a ser ouvida, com as devidas garantias e dentro de um prazo razoável, por um juiz ou tribunal competente, independente e imparcial, estabelecido anteriormente por lei, na apuração de qualquer acusação penal formulada contra ela, ou para que se determinem seus direitos ou obrigações de natureza civil, trabalhista, fiscal ou de qualquer outra natureza.

2.Toda pessoa acusada de delito tem direito a que se presuma sua inocência enquanto não se comprove legalmente sua culpa. Durante o processo, toda pessoa tem direito, em plena igualdade, às seguintes garantias mínimas:

a) direito do acusado de ser assistido gratuitamente por tradutor ou intérprete, se não compreender ou não falar o idioma do juízo ou tribunal;

b) comunicação prévia e pormenorizada ao acusado da acusação formulada;

c) concessão ao acusado do tempo e dos meios adequados para a preparação de sua defesa;

d) direito do acusado de defender-se pessoalmente ou de ser assistido por um defensor de sua escolha e de comunicar-se, livremente e em particular, com seu defensor;

e) direito irrenunciável de ser assistido por um defensor proporcionado pelo Estado, remunerado ou não, segundo a legislação interna, se o acusado não se defender ele próprio nem nomear defensor dentro do prazo estabelecido pela lei;

f) direito da defesa de inquirir as testemunhas presentes no tribunal e de obter o comparecimento, como testemunhas ou peritos, de outras pessoas que possam lançar luz sobre os fatos;

g) direito de não ser obrigado a depor contra si mesma, nem a declarar-se culpada;

h) direito de recorrer da sentença para juiz ou tribunal superior.

3. A confissão do acusado só é válida se feita sem coação de nenhuma natureza.

4. O acusado absolvido por sentença passada em julgado não poderá ser submetido a novo processo pelos mesmos fatos.

\footnotetext{
${ }^{13}$ CLADEM, Sistematização de Experiências em Litígio Internacional, outubro de 2009. p. 95.

${ }_{14} \mathrm{CIDH}$. Relatório sobre Acesso à Justiça para Mulheres Vítimas de Violência nas Américas.2007. Cap. I, para.24, p. 6.
} 
5. O processo penal deve ser público, salvo no que for necessário para preservar os interesses da justiça."

"Artigo 25: Proteção Judicial

1. Toda pessoa tem direito a um recurso simples e rápido ou a qualquer outro recurso efetivo, perante os juízes ou tribunais competentes, que a proteja contra atos que violem seus direitos fundamentais reconhecidos pela constituição, pela lei ou pela presente Convenção, mesmo quando tal violação seja cometida por pessoas que estejam atuando no exercício de suas funções oficiais.

2. Os Estados Partes comprometem-se:

a) assegurar que a autoridade competente prevista pelo sistema legal do Estado decida sobre os direitos de toda pessoa que interpuser tal recurso;

b) a desenvolver as possibilidades de recurso judicial; e

c) a assegurar o cumprimento, pelas autoridades competentes, de toda decisão em que se tenha considerado procedente o recurso."

"Artigo $1^{\circ}$ : Obrigação de respeitar os direitos:

1. Os Estados Partes nesta Convenção comprometem-se a respeitar os direitos e liberdades nela reconhecidos e a garantir seu livre e pleno exercício a toda pessoa que esteja sujeita à sua jurisdição, sem discriminação alguma por motivo de raça, cor, sexo, idioma, religião, opiniões políticas ou de qualquer outra natureza, origem nacional ou social, posição econômica, nascimento ou qualquer outra condição social."

O artigo $25^{15}$ combinado com o artigo 1.1 da Convenção Americana obriga o Estado a garantir que todo indivíduo tenha acesso à administração da justiça, e em particular, a um recurso rápido e efetivo, para que aqueles responsáveis pelas violações de direitos humanos possam ser processados e para que os danos sofridos sejam reparados. O artigo 25 está intimamente relacionado com o artigo 8.1 do mesmo instrumento, que consagra o direito de toda pessoa de ser ouvida com as devidas garantias e dentro de um prazo razoável, por um juiz ou tribunal independente e imparcial, para determinação de seus direitos, seja qual for a sua natureza. Em conseqüência, o Estado tem o dever de investigar as violações de direitos, processar os responsáveis e evitar a impunidade, agindo, portanto, com a devida diligência e cumprindo com a sua obrigação de garantia. ${ }^{16}$ Ainda

\footnotetext{
${ }^{15} \mathrm{O}$ artigo 25.1 incorpora o princípio, reconhecido no direito internacional dos direitos humanos, da efetividade dos instrumentos ou meios processuais destinados a garantir tais direitos. Ver Corte IDH, Opinião Consultiva OC - 9/87, de 06 de outubro de 1987, Garantias Judiciais no Estado de Emergência. para. 24.

${ }^{16}$ Ver, CORTE IDH. Caso Loayza Tamayo. Reparações. Sentença de 27 de novembro de 1998. par. 169. Caso Velásquez Rodríguez.Objeções Preliminares. 26 de junho de 1987. para. 91.
} 
em relação aos referidos artigos, insta ressaltar que o acesso efetivo à proteção judicial deve ser garantido, sem qualquer discriminação, o que fica demonstrado na relação dos artigos $8^{\circ}$ e 25 com o artigo 1.1 e com o artigo $24^{17}$ da Convenção, que garante a isonomia perante a lei. ${ }^{18} \mathrm{~A}$ discriminação de gênero, por exemplo, como iremos tratar em momento posterior, viola os direitos consagrados nesses artigos, impedindo que as mulheres vítimas de violência tenham acesso efetivo à justiça, perpetuando os atos de violência perpetrados e fortalecendo a ideia de que essas práticas são toleradas pela sociedade.

\subsubsection{Convenção Interamericana para Prevenir, Punir e Erradicar a Violência contra a Mulher (Convenção de Belém do Pará)}

A Convenção de Belém do Pará, adotada, em 09 de junho de 1994, pela OEA, e ratificada, em 27 de novembro de $1995^{19}$, pelo Brasil, promoveu um grande avanço para a compreensão e visibilidade da temática da discriminação de gênero ao ser o primeiro documento internacional a dispor sobre a definição de violência contra as mulheres. ${ }^{20}$ É, portanto, a primeira Convenção a tratar expressamente e reconhecer de forma enfática a violência contra a mulher como fenômeno generalizado, que ocorre no espaço público e privado, e que alcança, sem distinção, mulheres de várias raças, classes, religiões, idades, orientações sexuais e outras condições. ${ }^{21} \mathrm{~A}$

${ }^{17} \mathrm{O}$ artigo 24 da Convenção Americana estabelece que: "Todas as pessoas são iguais perante a lei. Por conseguinte, têm direito, sem discriminação, a igual proteção da lei."

18 Ver Relatório sobre Acesso à Justiça para Mulheres Vítimas de Violência nas Américas OEA/Ser.L/V//II, 20 Janeiro, 2007. Capítulo I. p. 6. Para. 25.

${ }^{19}$ Documentos básicos em matéria de Direitos Humanos do Sistema Interamericano. Convenção Interamericana Para Prevenir, Punir e Erradicar a Violência contra a Mulher (Convenção de Belém do Pará). Disponível em: http://www.cidh.org/Basicos/Portugues/n.Belem.do.Para.Ratif..htm. Acesso em: 03.10.10.

20 A Convenção de Belém do Pará também compõe o sistema especial de proteção no plano internacional, ou seja, o grupo de instrumentos internacionais criados para atender as especificidades daqueles indivíduos particularmente vulneráveis que merecem uma tutela especial, como também o faz a CEDAW. Esses documentos buscam atender a uma demanda internacional pelo reconhecimento das diferenças dos diversos grupos de indivíduos que não mais podiam ser tratados de forma genérica e abstrata.

${ }^{21}$ PIOVESAN, Flávia. Direitos Humanos e o Direito Internacional Constitucional. Editora Saraiva, São Paulo. $7^{a}$ Edição, 2007. p.190. 
Convenção de Belém do Pará estabelece um comprometimento no combate da violência de gênero entre os Estados, sendo o tratado com o maior número de ratificações dentro dos sistemas regionais de proteção dos direitos humanos ${ }^{22}$, conferindo aos Estados-Partes a responsabilidade de garantir os direitos das mulheres a uma vida livre de violência, tomando todas as medidas para prevenir a violência, investigar profundamente qualquer violação, garantir a responsabilização dos violadores e assegurar a existência de recursos adequados e efetivos para compensar as violações.

Como forma de monitoramento, a Convenção também exige que os Estados-Partes prestem informações sobre o cumprimento da Convenção, através do envio de relatórios à Comissão Interamericana de Mulheres. ${ }^{23} \mathrm{~A}$ Comissão Interamericana de Mulheres $(\mathrm{CIM})^{24}$ é o órgão da OEA com poder para avaliar se as normas previstas nessa Convenção estão sendo ou não cumpridas pelos Estados, através da atividade denominada Mecanismo de Seguimento da Convenção Interamericana para Prevenir, Punir e Erradicar a Violência contra a Mulher (MESECVI). ${ }^{25}$

A Convenção de Belém do Pará garante que qualquer pessoa, grupo de pessoas ou ONGs apresentem denúncias sobre violência cometida contra as mulheres. As denúncias são feitas por meio de petições, que devem ser enviadas à Comissão Interamericana de Direitos Humanos, até seis meses depois de esgotadas todas as medidas internas. A Convenção de Belém do

\footnotetext{
22 A Convenção para Prevenir, Punir e Erradicar a Violência contra a Mulher (Convenção de Belém do Pará) está em vigor para 32 dos países membros da Organização dos Estados Americanos (OEA). Ver Informe Anual/2001 da Comissão Interamericana de Direitos Humanos. Cap.VI - Trabalhos da Relatoria Especial sobre os Direitos da Mulher.

${ }^{23}$ O artigo10 da Convenção de Belém do Pará estabelece que: “A fim de proteger o direito de toda mulher a uma vida livre de violência, os Estados Partes deverão incluir nos relatórios nacionais à Comissão Interamericana de Mulheres informações sobre as medidas adotadas para prevenir e erradicar a violência contra a mulher, para prestar assistência à mulher afetada pela violência, bem como sobre as dificuldades que observarem na aplicação das mesmas e os fatores que contribuam para a violência contra a mulher."

${ }^{24}$ A Comissão Interamericana de Mulheres (CIM) foi criada em 1928, durante a Sexta Conferência Internacional Americana, realizada em Havana, Cuba. A CIM foi o primeiro organismo intergovernamental criado para tratar especificamente do tema dos direitos da mulher.

${ }^{25}$ O MESECVI é constituído por dois órgãos: a Conferência dos Estados Partes e o Comitê de Peritas (CEVI). A Conferência dos Estados Partes é o órgão político do Mecanismo, integra todos os Estados Partes da Convenção e se reúne a cada dois anos. Já o Comitê de Peritas é o órgão técnico do Mecanismo, integrado por peritas que exercem sua função a título pessoal. As peritas
} 
Pará também reconhece a Corte Interamericana de Direitos Humanos no exercício da sua competência consultiva, permitindo que os Estados e a Comissão Interamericana de Mulheres a consultem quando houver dúvida sobre a interpretação de algum artigo da Convenção ${ }^{26}$, e da sua competência contenciosa, permitindo que a Comissão Interamericana de Direitos Humanos envie casos à Corte IDH, desde que o Estado tenha reconhecido a sua jurisdição.

A Convenção de Belém do Pará, ao contrário da CEDAW que não possui nenhum artigo que trata expressamente da violência contra as mulheres, tendo que suprir essa "lacuna" através da elaboração da Recomendação Geral no 19 do Comitê $\mathrm{CEDAW}^{27}$, define, em seu artigo $1^{\text {o28 }}$, violência contra a mulher "como qualquer ação ou conduta, baseada em gênero, que cause morte, dano ou sofrimento físico, sexual ou psicológico à mulher". Para os efeitos da Convenção de Belém do Pará, portanto, a violência contra a mulher inclui a violência física, sexual e psicológica. A Convenção de Belém do Pará define também o seu âmbito de aplicação, advertindo que esses tipos de violência podem ocorrer tanto na vida pública como na privada, destacando os espaços relacionais onde a violência pode ser perpetrada. São eles: a violência ocorrida dentro da família, na unidade doméstica, ou em qualquer relação interpessoal, sem exigência de coabitação entre a vítima e o agressor; que tenha ocorrido na comunidade e que seja perpetrada por qualquer pessoa; ou que seja perpetrada ou tolerada pelo Estado ou seus agentes. ${ }^{29}$

\footnotetext{
são designadas por cada Estado Parte da Convenção entre seus nacionais. O Comitê é regido por um Regulamento próprio. Ver: http://www.oas.org/cim/english/MESECVI.Index.htm Acesso em ${ }^{26}$ O artigo11 da Convenção de Belém do Pará estabelece que: "Os Estados Partes nesta Convenção e a Comissão Interamericana de Mulheres poderão solicitar à Corte Interamericana de Direitos Humanos parecer sobre a interpretação desta Convenção.”

27 United Nations, Commitee on the Elimination of Discrimination against Women, General Recmmendation 19, Violende against Women, U.N. Doc. HRI/GEN/1/Rev. 1 (1994).

${ }^{28} \mathrm{O}$ artigo $1^{\circ}$ da Convenção para Prevenir, Punir e Erradicar a Violência contra a Mulher enuncia que: "Para os efeitos desta Convenção, entender-se-á por violência contra a mulher qualquer ato ou conduta baseada no gênero, que cause morte, dano ou sofrimento físico, sexual ou psicológico à mulher, tanto na esfera pública como na esfera privada."

29 O artigo $2^{\circ}$ da Convenção para Prevenir, Punir e Erradicar a Violência contra a Mulher define que: "Entende-se que a violência contra a mulher abrange a violência física, sexual e psicológica: a. ocorrida no âmbito da família ou unidade doméstica ou em qualquer relação interpessoal, quer o
} 
A Convenção de Belém do Pará reconhece em seu preâmbulo que a violência de gênero impede o reconhecimento e o gozo dos direitos e liberdades fundamentais das mulheres. $\mathrm{O}$ artigo $4^{\mathrm{o} 30}$ da Convenção estabelece alguns desses direitos, que são, entre outros: o direito a que se respeite sua vida; direito a que se respeite sua integridade física, mental e moral; direito à liberdade e à segurança pessoais; direito a não ser submetida à tortura; direito à igual proteção perante a lei e da lei; direito a recurso simples e rápido perante tribunal competente que a proteja contra atos que violem seus direitos; entre outros. $\mathrm{O}$ artigo $6^{031}$ deste instrumento destaca que o direito de toda mulher de ser livre de violência inclui, entre outros, o direito da mulher de ser livre de toda forma de discriminação; e o direito da mulher de ser valorizada e educada livre de padrões estereotipados de comportamento e práticas sócias e culturais baseadas em conceitos de inferioridade ou subordinação, reconhecendo a relação existente entre discriminação e violência baseada em gênero.

Os artigos $7^{\circ}$ e $8^{\circ}$ da Convenção de Belém do Pará estabelecem as obrigações negativas e positivas que os Estados devem cumprir a fim de prevenir, punir e erradicar a violência baseada em gênero, que inclui o dever de adequar a sua legislação e suas práticas internas aos padrões

agressor compartilhe, tenha compartilhado ou não a sua residência, incluindo-se, entre outras formas, o estupro, maus-tratos e abuso sexual; b. ocorrida na comunidade e cometida por qualquer pessoa, incluindo, entre outras formas, o estupro, abuso sexual, tortura, tráfico de mulheres, prostituição forçada, seqüestro e assédio sexual no local de trabalho, bem como em instituições educacionais, serviços de saúde ou qualquer outro local; c. perpetrada ou tolerada pelo Estado ou seus agentes, onde quer que ocorra."

$30 \mathrm{O}$ artigo $4^{\text {o }}$ determina que: "Toda mulher tem direito ao reconhecimento, desfrute, exercício e proteção de todos os direitos humanos e liberdades consagrados em todos os instrumentos regionais e internacionais relativos aos direitos humanos. Estes direitos abrangem, entre outros: a. direito a que se respeite sua vida; b. direito a que se respeite sua integridade física, mental e moral; c. direito à liberdade e à segurança pessoais; d. direito a não ser submetida a tortura; e. direito a que se respeite a dignidade inerente à sua pessoa e a que se proteja sua família; f. direito a igual proteção perante a lei e da lei; g. direito a recurso simples e rápido perante tribunal competente que a proteja contra atos que violem seus direitos; h. direito de livre associação; i. direito à liberdade de professar a própria religião e as próprias crenças, de acordo com a lei; e j. direito a ter igualdade de acesso às funções públicas de seu país e a participar nos assuntos públicos, inclusive na tomada de decisões."

${ }^{31} \mathrm{O}$ artigo $6^{a}$ da Convenção de Belém do Pará estabelece que: "O direito de toda mulher a ser livre de violência abrange, entre outros: a. o direito da mulher a ser livre de todas as formas de discriminação; e b. o direito da mulher a ser valorizada e educada livre de padrões estereotipados de comportamento e costumes sociais e culturais baseados em conceitos de inferioridade ou subordinação." 
internacionais e regionais de proteção estabelecidos pelos instrumentos de direitos humanos. Através destes artigos, a Convenção de Belém do Pará codifica o princípio da devida diligência, já estabelecido como padrão pelo Sistema Interamericano, identificando a importância da sua aplicabilidade nos casos de violência baseada em gênero. ${ }^{32} \mathrm{O}$ artigo $7^{\circ}$, que possui grande importância para o objetivo do presente trabalho, enumera medidas efetivas que os Estados-Partes devem adotar para atingir o objetivo da Convenção, principalmente, no que se refere às medidas para garantia do acesso à justiça das mulheres vítimas de violência:

Artigo $7^{\circ}$ : Deveres dos Estados

Os Estados Partes condenam todas as formas de violência contra a mulher e convêm em adotar, por todos os meios apropriados e sem demora, políticas destinadas a prevenir, punir e erradicar tal violência e a empenhar-se em:

a. abster-se de qualquer ato ou prática de violência contra a mulher e velar por que as autoridades, seus funcionários e pessoal, bem como agentes e instituições públicos ajam de conformidade com essa obrigação;

b. agir com o devido zelo para prevenir, investigar e punir a violência contra a mulher;

c. incorporar na sua legislação interna normas penais, civis, administrativas e de outra natureza, que sejam necessárias para prevenir, punir e erradicar a violência contra a mulher, bem como adotar as medidas administrativas adequadas que forem aplicáveis;

d. adotar medidas jurídicas que exijam do agressor que se abstenha de perseguir, intimidar e ameaçar a mulher ou de fazer uso de qualquer método que danifique ou ponha em perigo sua vida ou integridade ou danifique sua propriedade;

e. tomar todas as medidas adequadas, inclusive legislativas, para modificar ou abolir leis e regulamentos vigentes ou modificar práticas jurídicas ou consuetudinárias que respaldem a persistência e a tolerância da violência contra a mulher;

f. estabelecer procedimentos jurídicos justos e eficazes para a mulher sujeitada a violência, inclusive, entre outros, medidas de proteção, juízo oportuno e efetivo acesso a tais processos;

g. estabelecer mecanismos judiciais e administrativos necessários para assegurar que a mulher sujeitada a violência tenha efetivo acesso a restituição, reparação do dano e outros meios de compensação justos e eficazes;

h. adotar as medidas legislativas ou de outra natureza necessárias à vigência desta Convenção.

\footnotetext{
${ }^{32}$ ABI-MERSHED, Elizabeth, Due Diligence and the Fight against Gender Based Violence in the Inter- American System. IN: BENNINGER-BUDEL, Carin (Org). Due Diligence and its Application to Protect Women from Violence. Netherlands: Martinus Nijhoff Publishers, 2008. p. 129.
} 
$\mathrm{O}$ artigo $8^{\circ}$ enumera medidas específicas que os Estados-Partes devem adotar para atingir o objetivo da Convenção, que também terão sua relevância para análise dos padrões estabelecidos pelo Sistema Interamericano para garantia do acesso à justiça para mulheres vítimas de violência:

Artigo $8^{\circ}$ :

Os Estados Partes convêm em adotar, progressivamente, medidas específicas, inclusive programas destinados a:

a. promover o conhecimento e a observância do direito da mulher a uma vida livre de violência e o direito da mulher a que se respeitem e protejam seus direitos humanos;

b. modificar os padrões sociais e culturais de conduta de homens e mulheres, inclusive a formulação de programas formais e não formais adequados a todos os níveis do processo educacional, a fim de combater preconceitos e costumes e todas as outras práticas baseadas na premissa da inferioridade ou superioridade de qualquer dos gêneros ou nos papéis estereotipados para o homem e a mulher, que legitimem ou exacerbem a violência contra a mulher;

c. promover a educação e treinamento de todo o pessoal judiciário e policial e demais funcionários responsáveis pela aplicação da lei, bem como do pessoal encarregado da implementação de políticas de prevenção, punição e erradicação da violência contra a mulher;

d. prestar serviços especializados apropriados à mulher sujeitada a violência, por intermédio de entidades dos setores público e privado, inclusive abrigos, serviços de orientação familiar, quando for o caso, e atendimento e custódia dos menores afetados;

e. promover e apoiar programas de educação governamentais e privados, destinados a conscientizar o público para os problemas da violência contra a mulher, recursos jurídicos e reparação relacionados com essa violência;

f. proporcionar à mulher sujeitada a violência acesso a programas eficazes de reabilitação e treinamento que lhe permitam participar plenamente da vida pública, privada e social;

g. incentivar os meios de comunicação a que formulem diretrizes adequadas de divulgação, que contribuam para a erradicação da violência contra a mulher em todas as suas formas e enalteçam o respeito pela dignidade da mulher;

h. assegurar a pesquisa e coleta de estatísticas e outras informações relevantes concernentes às causas, conseqüências e freqüência da violência contra a mulher, a fim de avaliar a eficiência das medidas tomadas para prevenir, punir e erradicar a violência contra a mulher, bem como formular e implementar as mudanças necessárias; e

i. promover a cooperação internacional para o intercâmbio de idéias e experiências, bem como a execução de programas destinados à proteção da mulher sujeitada a violência. 
Em seu artigo $9^{\circ 33}$, a Belém do Pará reconhece a situação de maior vulnerabilidade à violência que as mulheres estão sujeitas em razão de sua raça ou de sua condição étnica, de migrante, refugiada ou desterrada. Além disso, solicita maior atenção aos graves riscos de violência contra a mulher grávida, excepcional, menor de idade, idosa, em situação socioeconômica desfavorável ou afetada por situações de conflito armado ou de privação de sua liberdade. ${ }^{34}$ Nesse sentido, podemos analisar quem são as "mulheres" protegidas pela Convenção Belém do Pará. Podemos observar que há inúmeras diferenças entre as mulheres, não havendo uma só mulher, mas sim as mais diversas mulheres, e aquilo que forma a pauta de reivindicações de algumas, não necessariamente forma a pauta de outras. Algumas mulheres situam-se em interseccionalidades, como classe e raça, que as colocam em uma situação de maior vulnerabilidade que demanda uma tutela especial do poder estatal. A maior dificuldade de acesso à justiça enfrentada por mulheres negras e indígenas é um exemplo de que a discriminação de gênero ainda pode ser agravada por outras formas de discriminação. Mesmo em seu preâmbulo, já podemos identificar a atenção da Convenção às muitas interseccionalidades ao salientar que "... a violência de gênero transcende todos os setores da sociedade, independentemente de sua classe, raça ou grupo étnico, níveis de salário, cultura, nível educacional, idade ou religião, e afeta negativamente suas próprias bases". Importante ressaltar que igualmente à CEDAW, a Convenção de Belém do Pará não faz nenhuma referência à orientação

\footnotetext{
${ }^{33}$ O artigo $9^{\text {a }}$ da Convenção de Belém do Pará estabelece que: "Para a adoção das medidas a que se refere este capítulo, os Estados Partes levarão especialmente em conta a situação da mulher vulnerável a violência por sua raça, origem étnica ou condição de migrante, de refugiada ou de deslocada, entre outros motivos. Também será considerada sujeitada a violência a gestante, deficiente, menor, idosa ou em situação sócio-econômica desfavorável, afetada por situações de conflito armado ou de privação da liberdade."

${ }^{34}$ Os relatórios produzidos pela Comissão Interamericana e pela Relatoria Especial sobre os Direitos da Mulher evidenciam que o Sistema Interamericano de Direitos Humanos tem dado especial atenção as particularidades das mais diferentes mulheres e reconhecido a vulnerabilidade em casos de interseccionalidades. Os relatórios sobre Violência e Discriminação contra a Mulher no Conflito Armado na Colômbia (2006); sobre o Direito das Mulheres no Haiti a um Vida Livre de Violência e Discriminação (2009); e o mais recente relatório sobre Acesso à Serviços de Saúde de Maternidade sobre a Perspectiva dos Direitos Humanos (2010) são exemplos que confirmam esse reconhecimento.
} 
sexual das diversas mulheres que também são vítimas de violência baseada em gênero. ${ }^{35}$

O artigo $12^{36}$ da Convenção de Belém do Pará estabelece o mecanismo de petições individuais, que permite que qualquer pessoa, grupo de indivíduos, ou entidade não-governamental possa apresentar à Convenção Interamericana de Direitos Humanos comunicações que contenham denúncias de violações do artigo $7^{\circ}$ da Convenção, que prevê os deveres dos Estados-Partes. A Comissão Interamericana considerá-las-á de acordo com as normas e os requisitos de procedimento para apresentação de petições estipulados na Convenção Americana sobre Direitos Humanos e no Estatuto e Regulamento da Comissão Interamericana de Direitos Humanos.

\subsection{Competência dos órgãos do Sistema Interamericano na luta contra a discriminação de gênero}

O Sistema Interamericano de Direitos Humanos é um sistema bifásico, contando com dois órgãos distintos: a Comissão Interamericana de Direitos Humanos e a Corte Interamericana de Direitos Humanos. A expansão das faculdades da Comissão Interamericana de Direitos Humanos, a institucionalização convencional do sistema, a entrada em vigor da Convenção Americana de Direitos Humanos (Pacto de San José da Costa Rica), em 1978, a evolução da jurisprudência da Corte Interamericana de Direitos Humanos, conjuntamente com a adoção de novos instrumentos de

\footnotetext{
${ }^{35}$ No que se refere à diversidade de orientação sexual e a discriminação sofrida por mulheres, em 17 de setembro de 2010, a Comissão Interamericana submeteu à Corte Interamericana o caso Karen Atala e filhas vs. Chile, em razão do tratamento discriminatório contra a vítima que perdeu a guarda de suas filhas devido a sua orientação sexual, criando a oportunidade de criação de um precedente sobre a matéria. Ver Comunicado de Imprensa $\mathrm{n}^{\circ}$ 97/10 em: http://www.cidh.org/comunicados/spanish/2010/97-10sp.htm Acesso em: 20.10.10.

${ }^{36} \mathrm{O}$ artigo 12 da Convenção de Belém do Pará estabelece que: "Qualquer pessoa ou grupo de pessoas, ou qualquer entidade não-governamental juridicamente reconhecida em um ou mais Estados membros da Organização, poderá apresentar à Comissão Interamericana de Direitos Humanos petições referentes a denúncias ou queixas de violação do artigo $7^{\circ}$ desta Convenção por um Estado-Parte, devendo a Comissão considerar tais petições de acordo com as normas e procedimentos estabelecidos na Convenção Americana sobre Direitos Humanos e no Estatuto e Regulamento da Comissão Interamericana de Direitos Humanos, para a apresentação e consideração de petições.
} 
proteção, como a Convenção de Belém do Pará, foram determinantes para o progresso e consolidação do Sistema Interamericano de Proteção e para internacionalização dos direitos humanos dos indivíduos no continente americano. $^{37}$

\subsubsection{Comissão Interamericana de Direitos Humanos e a Relatoria Especial sobre os Direitos da Mulher}

A Comissão Interamericana de Direitos Humanos, originada, em 1959, da Resolução VIII da V Reunião de Consulta dos Ministros de Relações Exteriores (Santiago do Chile), e prevista na Carta a partir da Emenda X, é um órgão autônomo da Organização dos Estados Americanos (OEA), representando todos os países membros da OEA. ${ }^{38}$ Está integrada por sete membros independentes que atuam de forma pessoal, os quais não representam nenhum país em particular, sendo eleitos pela Assembléia Geral. A CIDH que, segundo o seu Estatuto de 1960, tinha o seu mandato limitado à promoção dos direitos humanos, ampliou com a $\mathrm{CADH}$ os seus poderes para receber petições e comunicações sobre violações de direitos humanos; realizar visitas in loco em alguns países; elaboração de relatórios e estudos temáticos; criação de relatorias especiais; dentre outras atribuições. $^{39}$

\footnotetext{
37 TRINDADE, Antônio A. Tratado de direito Internacional dos Direitos Humanos. Vol. III. $1^{\text {a ed. }}$ Porto Alegre: Sergio Antonio Fabris Editor, 2003. pp.30-31.

38 A Convenção Americana, criada antes da Convenção Americana sobre Direitos Humanos, possui atribuições em relação a todos os Estados membros da OEA, englobando, portanto, os Estados ratificantes e não-ratificantes da Convenção Americana.

39 Estão entre as funções da CIDH: a) receber, analisar e investigar petições individuais que alegam violações dos direitos humanos, segundo o disposto nos artigos 44 a 51 da Convenção; b) observar o cumprimento geral dos direitos humanos nos Estados membros, e quando o considera conveniente, publicar as informações especiais sobre a situação em um estado específico; c) realizar visitas in loco aos países para aprofundar a observação geral da situação, e/ou para investigar uma situação particular. Geralmente, essas visitas resultam na preparação de um relatório respectivo, que é publicado e enviado à Assembléia Geral; d) estimular a consciência dos direitos humanos nos países da America. Além disso, realizar e publicar estudos sobre temas específicos como, por exemplo, sobre: medidas para assegurar maior independência do poder judiciário; atividades de grupos armados irregulares; a situação dos direitos humanos dos menores, das mulheres e dos povos indígenas; e) realizar e participar de conferencias e reuniões com diversos tipos de representantes de governo, universitários, organizações não governamentais, etc... para difundir e analisar temas relacionados com o sistema interamericano de direitos humanos. f) fazer recomendações aos Estados membros da OEA acerca da adoção de medidas para contribuir com a promoção e garantia dos direitos humanos; g) requerer aos Estados membros que adotem "medidas cautelares" específicas para evitar danos graves e irreparáveis aos direitos humanos em casos urgentes. Pode também solicitar que a Corte Interamericana requeira "medidas
} 
No que se refere à sua competência para recebimento de petições individuais, são muitos os casos encaminhados à Comissão Interamericana alegando atos de violência de gênero e a falta de acesso efetivo à justiça para mulheres vítimas de violência. Dentre os casos mais importantes sobre o tema ${ }^{40}$, que será abordado em momento posterior, está o caso Maria da Penha vs. Brasil ${ }^{41}$, decidido pela Comissão, em 2001. O caso Maria da Penha, que será abordado aqui em momento posterior, tem a sua grande importância atribuída ao fato de ter sido o primeiro caso em que se aplicou a Convenção de Belém do Pará no Sistema Interamericano, especialmente com uma decisão na qual um país é responsabilizado internacionalmente pela violência doméstica contra as mulheres. ${ }^{42} \mathrm{O}$ caso foi responsável pelo fortalecimento da ideia de que a violência doméstica é uma grave violação de direitos humanos e que o Estado deve atuar para prevenir, punir e erradicar essas práticas degradantes contra a mulher, mesmo que os atos violentos sejam praticados no âmbito doméstico e nas relações interpessoais, espaços onde se considerava que o poder estatal não deveria interferir.

A CIDH, buscando dar plena efetividade aos direitos das mulheres no continente americano, criou a Relatoria Especial sobre os Direitos da Mulher, em 1994. A Relatoria foi estabelecida com um mandato inicial para analisar se as leis e práticas dos Estados-Partes cumpriam as obrigações de

provisionais" dos Governos em casos urgentes de grave perigo às pessoas, ainda que o caso não tenha sido submetido à Corte; $h$ ) remeter os casos à jurisdição da Corte Interamericana e atuar frente à Corte em determinados litígios; i) solicitar "Opiniões Consultivas" à Corte Interamericana sobre aspectos de interpretação da Convenção Americana.

${ }^{40}$ Além do caso do caso Maria da Penha (Relatório no 54/01), outros exemplos recentes de casos da CIDH relacionados à violência baseada em gênero e acesso à justiça são: Relatório $\mathrm{n}^{\circ}$ 53/01mérito, caso Ana, Beatriz e Cecilia González Pérez (México); Relatório 73/01, caso 12.350, MZ (Bolívia); Mérito, № 4/01, Maria Eugenia Morales de Sierra (Guatemala). Janeiro 19, 2001; Relatório no 71/03- caso Maria Mamérita Mestanza Chávez (Peru); Relatório de Solução Amistosa, No 21/07, Paulina Del Carmen Ramírez Jacinto (México). Março 9, 2007.

${ }^{41}$ Em 1983, Maria da Penha Maia Fernandes, farmacêutica, foi vítima de dupla tentativa de homicídio pelo seu marido dentro de sua própria residência, localizada em Fortaleza, Ceará. O agressor atirou em suas costas enquanto a vítima dormia o que acarretou uma paraplegia irreversível e outros traumas, tanto físicos como psicológicos. Em ocasião posterior, tentou ele eletrocutá-la, enquanto tomava banho. O caso Maria da Penha, juntamente com as recomendações feitas ao Brasil pelo Comitê CEDAW sobre a violência doméstica contra a mulher, tiveram grande influência na criação da Lei 11.340/2006 (Lei Maria da Penha), evidenciando um grande impacto do direito internacional dos direitos humanos no direito brasileiro. 
garantia de igualdade e não-discriminação, princípios básicos do Sistema Interamericano de Proteção dos Direitos Humanos, em relação às mulheres. Posteriormente, a Comissão e a Relatoria deram especial ênfase para o problema de violência contra as mulheres, como uma manifestação da discriminação baseada em gênero, como reconhecido pela Convenção de Belém do Pará. ${ }^{43}$ Após terem analisado a situação das mulheres vítimas de violência em diversos contextos, a CIDH e a Relatoria observaram os fortes obstáculos que elas enfrentam para obterem a efetiva proteção e garantia judicial. Nesse sentido, há dois anos a Relatoria vem tratando esse tema como desafio prioritário, procurado financiamento externo para dedicar atenção adicional para a questão do acesso à justiça para mulheres vítimas de violência. ${ }^{44}$

A Relatoria possui como principais atividades: a realização de visitas in loco; a elaboração de estudos e relatórios temáticos ${ }^{45}$; atividades de cooperação com a sociedade civil; auxílio no trâmite de petições individuais encaminhadas à CIDH, através da pesquisa de informações, jurisprudência, etc; e a elaboração de relatórios específicos sobre a situação dos direitos humanos das mulheres nos Estados-Partes.

\subsubsection{Corte Interamericana de Direitos Humanos}

A Convenção Americana estabeleceu como seu órgão jurisdicional autônomo, a Corte Interamericana de Direitos Humanos ${ }^{46}$, instalada em São

\footnotetext{
43 CIDH, Relatório Anual da Comissão Interamericana de Direitos Humanos, 2001. Cap. VI. Relatório Atualizado sobre o Trabalho da Relatoria sobre os Direitos da Mulher.

${ }^{44}$ Special Rapporteurship on the Rights of Women of the Inter-American Comission on Human Rights. Acesso: http://www.cidh.org/women/mandate.htm. Acesso em: 12.10.2010.

45 São alguns dos relatórios temáticos produzidos pela CIDH e pela Relatoria Especial sobre os Direitos da Mulher: Status da Mulher nas Américas (1997/98); A Situação dos Direitos das Mulheres na Ciudad Juárez, México (2003); Violence and Discrimination against Women in the Armed Conflit in Colombia (2006); Access to Justice for Women Victms of Violence in the Americas (2007); The Right of Women in Haiti to be Free from Violence and Discrimination (2009); Report on the Rights of Women in Chile: Equality in the Family, Labor and Political Spheres (2009); Access to Maternal Health Services from a Human Rights Perspective (2010).

${ }^{46}$ Trata-se de tribunal composto por sete juízes nacionais dos Estados-membros da OEA, eleitos a título pessoal dentre juristas da mais alta autoridade moral, de reconhecida competência em matéria de direitos humanos, que reúnam as condições requeridas para o exercício das mais elevadas funções judiciais, de acordo com a lei do Estado do qual sejam nacionais.
} 
José da Costa Rica, desde 1979. A Convenção atribuiu à Corte Interamericana duas competências: uma de caráter consultivo e uma de caráter contencioso. No âmbito da sua atribuição consultiva, qualquer Estado membro da OEA, signatário ou não da Convenção Americana, pode solicitar a opinião consultiva da Corte em relação à interpretação e ao alcance das disposições da Convenção Americana ou de qualquer outro dispositivo de documento de direitos humanos no âmbito da OEA.

No plano contencioso, sua competência para o julgamento de casos é limitada aos Estados Partes da Convenção que tenham expressamente reconhecido sua jurisdição. Essa competência consiste na apreciação de questões envolvendo denúncia de violação de qualquer direito previsto pela $\mathrm{CADH}^{47}$. Somente a CIDH e os Estados Partes da CADH podem submeter um caso à decisão da Corte IDH, não havendo a possibilidade do indivíduo apresentar uma demanda diretamente ao órgão. No entanto, nota-se que os indivíduos vêm adquirindo maior espaço durante o litígio ${ }^{48}$, o que se confirma pela vigência do V Regulamento da Corte IDH, desde o início de 2010. A CIDH, desse modo, já não inicia o procedimento perante a Corte com a apresentação de uma demanda, senão com a remissão de seu relatório de mérito, emitido conforme prevê o artigo 50 da Convenção Americana. A demanda passa a ser, portanto, da competência das vítimas e de seus representantes. Ao emitir tal informe, a Comissão deverá apresentar os fundamentos, de fato e de direito, que a levaram a submeter o caso à Corte.

\footnotetext{
${ }^{47}$ No âmbito da competência contenciosa, também podemos citar as medidas provisórias de proteção ordenadas pela Corte Interamericana de Direitos Humanos, que revelam uma proteção com caráter preventivo dentro do Sistema Interamericano. A Corte ordena essas medidas em casos de extrema gravidade ou urgência, em que haja uma presunção razoável da veracidade dos fatos alegados, de modo a evitar danos irreparáveis aos indivíduos envolvidos. TRINDADE, Antônio A. Tratado de direito Internacional dos Direitos Humanos. Vol. III. 1 ${ }^{\mathrm{a} e d}$. Porto Alegre: Sergio Antonio Fabris Editor, 2003.p.55.

${ }^{48}$ Antes do V Regulamento, os III e IV Regulamentos da Corte já demonstravam a evolução do sistema no sentido de conceder maior protagonismo aos indivíduos. O III Regulamento da Corte, de 1996, trouxe uma inovação autorizando que os representantes ou familiares das vítimas apresentassem, de forma autônoma, suas próprias alegações e provas durante a etapa de discussão sobre as reparações devidas pelos Estados. Já o IV Regulamento, estabeleceu também a possibilidade de que as vítimas, seus representantes e familiares façam o uso da palavra durante as audiências.
} 
A competência contenciosa da Corte IDH para julgar violações ao artigo $7^{\circ}$ da Convenção de Belém do Pará não é expressa, ao contrário da sua competência consultiva, que vem prevista no artigo $11^{49}$ da Convenção de Belém do Pará, e que permite que os Estados-Partes e a Comissão Interamericana de Mulheres requeiram à Corte IDH opinião consultiva sobre a interpretação da Convenção de Belém do Pará. No entanto, a competência contenciosa desse tribunal para julgar violações ao artigo $7^{\circ}$ da Convenção de Belém do Pará foi confirmada expressamente pela Corte IDH na sentença do caso Campo Algodonero vs. México ${ }^{50}$, cuja análise terá grande relevância para o objetivo do presente trabalho. Este caso será abordado detalhadamente no capítulo 3 do trabalho, que também analisará especificamente a jurisprudência da Corte IDH em relação ao tema da discriminação e violência baseadas em gênero.

\footnotetext{
49 O artigo 11 da Convenção de Belém do Pará estabelece que: “Os Estados Partes nesta Convenção e a Comissão Interamericana de Mulheres poderão solicitar à Corte Interamericana de Direitos Humanos parecer sobre a interpretação desta Convenção."

${ }^{50}$ CORTE IDH, Caso González y Otras ("Campo Algodonero") vs. México. Sentença de 16 de novembro de 2009. para. 35-59.
} 


\section{Capítulo 2. Os padrões de acesso à justiça do Sistema Interamericano de Proteção dos Direitos Humanos para mulheres vítimas de violência}

\subsection{Discriminação e violência baseadas em gênero}

No presente capítulo iremos tratar os entendimentos adotados pela CIDH e por sua Relatoria Especial em casos individuais ou em relatórios temáticos acerca da temática da discriminação e violência baseadas em gênero e do acesso à justiça para mulheres vítimas de violência. Como indicado no ponto anterior, os padrões estabelecidos pela jurisprudência da Corte IDH serão tratados especificamente no capítulo seguinte do trabalho.

Conforme já estabelecido em diversos instrumentos internacionais de proteção dos direitos humanos, o fenômeno da violência baseada em gênero é resultado de relações desiguais de poder entre homens e mulheres, que relegam à mulher uma posição de subordinação e impedem o seu desenvolvimento e o pleno gozo dos seus direitos fundamentais. ${ }^{51}$ Entretanto, na prática, a resposta aos atos de violência tem sido fragmentada e tratada de forma isolada da questão de garantia dos direitos da mulher e dos princípios da igualdade e a não-discriminação. O Sistema Interamericano estabeleceu a íntima relação existente entre a obrigação de garantir a igualdade e não-discriminação e evitar a violência contra a mulher. A Comissão Interamericana considera que a violência baseada em gênero é uma manifestação de costumes e práticas de uma estrutura social patriarcal que inferioriza as mulheres e que cria papéis culturais estereotipados para homens e mulheres, fortalecendo a desigualdade e a discriminação. ${ }^{52}$

\footnotetext{
${ }^{51}$ Preâmbulo da Declaração para Eliminação da Violência contra as Mulheres e artigo $6^{\circ}$ da Convenção de Belém do Pará.

${ }^{52} \mathrm{CIDH}$, Relatório sobre Acesso à Justiça para Mulheres Vítimas de Violência nas Américas, OEA/Ser.L/V//II, 20 Janeiro, 2007. Capítulo I. p.15. para.59.
} 
O artigo 1(1) da Convenção Americana prevê que os Estados-Partes da Convenção comprometam-se a garantir os direitos e liberdades reconhecidos na Convenção, sem discriminação, com base na raça, cor, sexo, idioma, religião, opiniões políticas ou de qualquer outra natureza, origem nacional ou social, posição econômica, nascimento ou qualquer outra condição social. Em complemento ao princípio da não-discriminação contido no referido artigo, o artigo 24 da Convenção Americana reconhece o direito à igual proteção da lei e perante a lei. $\mathrm{O}$ artigo 24, portanto, reitera de forma específica a obrigação geral de respeito e garantia de direitos, "sem discriminação", prevista no artigo 1(1), proibindo qualquer forma de discriminação, não só em relação aos direitos consagrados na Convenção, mas também em relação a todas as leis que os Estados adotem e também na forma de aplicação dessas leis.

Como já apresentado em momento anterior, a Convenção de Belém do Pará reconhece, expressamente, em seu artigo $6^{\circ}$ a relação existente entre violência baseada em gênero ${ }^{53}$ e discriminação de gênero ao definir que o direito a uma vida livre de violência inclui o direito a ser livre de toda forma de discriminação e de ser educada segundo padrões estereotipados de comportamento. A CIDH, utilizando a Recomendação Geral no $19^{54}$ do Comitê CEDAW, que incluí a violência de gênero no $\operatorname{artigo} 1^{\mathrm{o}} \mathrm{da}$ $\mathrm{CEDAW}^{55}$, o qual dispõe sobre a definição de discriminação de gênero, observa que a violência de gênero é uma forma de discriminação contra a

\footnotetext{
${ }^{53}$ A definição de violência de gênero que é usada como referência pelo Sistema Interamericano de Proteção dos Direitos Humanos é a definição prevista nos artigos $1^{\circ}$ e $2^{\circ}$ da Convenção de Belém do Pará que define violência baseada em gênero como qualquer ato ou conduta, baseada em gênero, que cause morte ou dano físico, psicológico ou sexual ou sofrimento à mulher, na esfera pública e privada. Ver CIDH, Relatório sobre Acesso à Justiça para Mulheres Vítimas de Violência nas Américas, OEA/Ser.L/V//II, 20 Janeiro, 2007. Capítulo I para. 10.

${ }^{54}$ United Nations, Committee on the Elimination of Discrimination against Women, General Recommendation 19, Violence against Women, U.N. Doc. HRI/GEN/1/Rev.1 (1994).

${ }^{55}$ A CEDAW estabelece em seu artigo $1^{\circ}$ : "Para os fins da presente Convenção, a expressão "discriminação contra a mulher" significará toda a distinção, exclusão ou restrição baseada no sexo e que tenha por objeto ou resultado prejudicar ou anular o reconhecimento, gozo ou exercício pela mulher, independentemente de seu estado civil, com base na igualdade do homem e da mulher, dos direitos humanos e liberdades fundamentais nos campos político, econômico, social, cultural e civil ou em qualquer outro campo."
} 
mulher, que tem como base a diferença histórica de poderes entre homens e mulheres e o tratamento subordinado que as mulheres recebem.

A Comissão Interamericana analisa a relação existente entre as diferenças hierárquicas entre homens e mulheres, principalmente no âmbito familiar, e a discriminação e violência baseadas em gênero, em dois importantes casos, o caso Maria da Penha vs. Brasil e o caso Maria Eugenia Morales de Sierra vs. Guatemala ${ }^{56}$ Enquanto o caso Maria da Penha se apresenta como referência nos casos de violência doméstica, sendo o primeiro caso em que houve a aplicação da Convenção Belém do Pará, o caso Maria Eugenia Morales da Sierra representa um grande passo na determinação da eliminação da discriminação de jure referente aos direitos e deveres da mulher e do homem no matrimônio. ${ }^{57}$ Outro ponto em comum entre os casos é a dicotomia existente entre os espaços e atos públicos e privados, que cria a ideia de que as questões domésticas e familiares estão fora do alcance do Estado, resultando na tolerância estatal de atos de discriminação contra a mulher no âmbito privado. ${ }^{58}$

No caso Maria da Penha vs. Brasil, a CIDH decidiu pela responsabilização do Brasil pela violação dos direitos às garantias judiciais e à proteção judicial, consagrados nos artigos $8^{\circ}$ e 25 , em concordância com a obrigação geral de respeitar e garantir os direitos, prevista no artigo $1.1 \mathrm{da}$ Convenção Americana. A CIDH combinou estes artigos da Convenção Americana com o artigo $7^{\circ}$ da Convenção Belém do Pará, em razão da negligência e falta de efetividade do Estado para processar e punir os

\footnotetext{
${ }^{56}$ CIDH, Mérito, № 4/01, Maria Eugenia Morales de Sierra (Guatemala). Janeiro 19, 2001.

${ }^{57} \mathrm{CIDH}$, Relatório sobre Acesso à Justiça para Mulheres Vítimas de Violência nas Américas, OEA/Ser.L/V//II, 20 Janeiro, 2007. Capítulo I. p.15. para. 60-61.

${ }^{58}$ A Corte Européia de Direitos Humanos, no caso Opuz vs.Turquia, mencionado pela CIDH no seu Relatório de Acesso à Justiça para Mulheres Vítimas de Violência nas Américas, 2007, traz a seu entendimento acerca da falsa oposição entre o direito à privacidade e à família e o direito à integridade pessoal. Nesse caso, em que há a alegação de violência doméstica contra a vítima e sua mãe, a Corte estabeleceu que o direito à privacidade não é um direito absoluto e que o poder público deve limitar o alcance desse direito quando for necessária a sua ingerência para garantir os direitos e liberdades dos indivíduos. $\mathrm{O}$ direito à privacidade também inclui o direito ao bem estar dos indivíduos e não deve ser uma barreira entre o Estado e os cidadãos quando for necessária a atuação estatal para cumprir com a sua obrigação positiva para prevenir os casos de violência doméstica e garantir os direitos das mulheres vítimas de violência. (Ver Corte EDH, caso Opuz vs.Turquia. 9 de junho de 2009, para. 180, 191 e 200.)
} 
agressores, como também para prevenir a violência doméstica no Brasil, criando a ideia de aceitabilidade dessas práticas e um ambiente favorável para perpetuação de padrões discriminatórios contra a mulher. ${ }^{59}$ Já no caso Maria Eugenia Morales de Sierra vs. Guatemala, o estado da Guatemala foi responsabilizado pela violação dos artigos 1, 2, 17 e 24 da Convenção Americana, em razão das previsões legais discriminatórias do Código Civil da Guatemala no que se refere à divisão de responsabilidades entre homens e mulheres durante a vigência do casamento. Segundo a Comissão, essas distinções, que caracterizavam o homem como responsável pelo sustento da família, e a mulher como responsável pelos cuidados da casa e da família, institucionalizavam a desigualdade de direitos e deveres entre homens e mulheres na família. ${ }^{60}$

Esses papéis estereotipados perpetuam a discriminação de facto contra as mulheres no contexto familiar, legitimam atos de violência no âmbito doméstico e fortalecem a tolerância social a essas práticas. Os papéis estereotipados desempenhados por homens e mulheres são na maioria das vezes uma grande barreira para as próprias mulheres vítimas de violência que as força a permanecer em uma relação de violência com o seu companheiro. No caso Maria Eugenia Morales, a Comissão utilizou a Recomendação Geral no 19 do Comitê CEDAW para destacar que o fato dos homens assumirem muitas vezes a posição de provedor das necessidades familiares juntamente com a ausência de independência econômica das suas companheiras força muitas mulheres a manterem o seu relacionamento com o agressor. ${ }^{61}$ Outros fatores da permanência das mulheres em relações violentas são a preocupação com a integridade

\footnotetext{
${ }^{59}$ CIDH, Mérito, No 54/01, Maria da Penha Fernandes (Brasil). Abril 16, 2001.para.47.

${ }^{60} \mathrm{CIDH}$, Mérito, No 4/01, Maria Eugenia Morales de Sierra (Guatemala). Janeiro 19, 2001. para.44-48.

${ }^{61}$ A Recomendação Geral no 19 enuncia que: "a violência familiar é uma das mais insidiosas formas de violência contra as mulheres e é prevalente em todas as sociedades. No âmbtio familiar, mulheres de todas as idades estão sujeitas à violência de todos os tipos, incluindo o estupro espancamento, outras formas de agressão sexual, mental e outras formas de violência que são perpetuadas por atitudes tradicionais. A falta de independência econômica forças muitas mulheres a permanecer em relacionamentos violentos. (...) Estas formas de violência colocam a saúde das
} 
familiar e com os filhos, o descrédito nos mecanismos de acesso à justiça e o temor de que sejam novamente violentadas pelo agressor após ser descoberta a denúncia. Como será abordado a seguir, os papéis estereotipados e discriminatórios tradicionalmente desempenhados por homens e mulheres que as relegam a uma posição de subordinação e inferioridade, demonstram-se como causa das práticas de violência, como causa da ausência de acesso de facto à justiça pelas mulheres vítimas de violência e como causa da impunidade e consequiente disseminação dessas práticas.

A Comissão Interamericana estabelece que o princípio da não discriminação quando usado para analisar questões relacionadas à discriminação de gênero possui duas dimensões, uma mais estreita e outra mais ampla. ${ }^{62}$ A formulação mais estreita, associada ao liberalismo clássico, visa proibir leis, práticas e políticas que fortaleçam estereótipos de gênero e a discriminação contra as mulheres, que as impedem de desempenhar certas práticas, que devem ser apenas exercidas por homens. Portanto, o princípio da não discriminação nessa formulação afirma que as pessoas não devem ser tratadas como desiguais com base no gênero e está associado com a distribuição de oportunidades e recursos escassos entre os grupos, em que o gênero não é um fator. O que mais importa para essa posição liberal clássica é que a lei seja elaborada de forma neutra e objetiva. A igualdade de tratamento será suficiente para compensar as desvantagens que as mulheres enfrentam. ${ }^{63}$

Já a formulação mais ampla do conceito de não-discriminação está associada com a ideia de eliminar a discriminação das mulheres como um grupo, a partir de uma perspectiva de não-subordinação. Busca-se condenar e eliminar práticas que tenham o efeito de perpetuar a posição subordinada

mulheres em risco de deficiência e sua capacidade de participar na vida familiar e vida pública em igualdade de condições.

${ }^{62} \mathrm{CIDH}$, Relatório sobre Acesso à Justiça para Mulheres Vítimas de Violência nas Américas, OEA/Ser.L/V//II, 20 Janeiro, 2007. Capítulo I. p.18. para. 72.

${ }^{63} \mathrm{CIDH}$, Relatório sobre Acesso à Justiça para Mulheres Vítimas de Violência nas Américas, OEA/Ser.L/V//II, 20 Janeiro, 2007. Capítulo I. p.18. para. 73. 
de determinados grupos desfavorecidos, como as mulheres. "Por esta definição de não-discriminação, a discriminação contra as mulheres é inaceitável não só porque pressupõe um tratamento injusto para algumas mulheres, mas também porque sua função é a subordinação das mulheres como um grupo e, assim, criar e perpetuar uma hierarquia de gênero". ${ }^{64}$ A interpretação ampla desse princípio instiga a análise de normas e padrões aparentemente neutros que possuem efeitos mais gravosos para as mulheres, discriminando-as de forma indireta. A análise dessa norma não deve ser feita somente em relação aos seus feitos para algumas mulheres, mas em relação ao prejuízo causado para muitas outras mulheres que sofrem o mesmo dano por estarem incluídas em um grupo subordinado pelos padrões discriminatórios da sociedade patriarcal. ${ }^{65}$

Outro ponto vantajoso dessa formulação mais ampla do princípio da não discriminação é que ela ajuda a justificar a ingerência do Estado para atuar positivamente na criação de condições reais para a promoção dessa igualdade através de políticas de ação afirmativa, como, por exemplo, cotas de participação em órgãos políticos ou a manutenção de creches públicas de qualidade para que mulheres possam trabalhar ou estudar. É também essa formulação de não discriminação adotada pela CEDAW, conforme previsto em seu artigo $4^{\circ}$ e na Recomendação Geral no 25 do Comitê CEDAW, que estabelecem que os Estados devem adotar medidas especiais de caráter temporário destinadas a acelerar a igualdade de facto entre o homem e a mulher e essas medidas não serão consideradas discriminatórias. Esses dois dispositivos serão padrões de interpretação e avaliação das medidas de ações de medida afirmativa utilizados pela Comissão Interamericana. ${ }^{66}$

\footnotetext{
${ }^{64} \mathrm{CIDH}$, Relatório sobre Acesso à Justiça para Mulheres Vítimas de Violência nas Américas, OEA/Ser.L/V//II, 20 Janeiro, 2007. Capítulo I. p.19. para. 75.

${ }^{65} \mathrm{CIDH}$, Relatoria Especial sobre os Direitos da Mulher. Relatório sobre Acesso à Justiça para Mulheres Vítimas de Violência nas Américas, OEA/Ser.L/V//II, 20 Janeiro, 2007. Capítulo I. p.19. para. 75

${ }^{66} \mathrm{CIDH}$, Relatoria Especial sobre os Direitos da Mulher. Relatório sobre Acesso à Justiça para Mulheres Vítimas de Violência nas Américas, OEA/Ser.L/V//II, 20 Janeiro, 2007. Capítulo I. p.19. para. 78.
} 
A Comissão Interamericana também estabelece que discriminação possui várias faces: uma é a discriminação causada por um tratamento desigual baseado em um fator, como o gênero, que impede, restringe ou afeta o exercício de um direito, se manifestando em um tratamento separado ou excludente em relação a um determinado grupo. ${ }^{67}$ Outra forma de discriminação ocorre quando uma obrigação legal de adotar as medidas estabelecidas pelo direito doméstico e internacional não é preenchida, como nos casos abordados em que o Estado atuou de forma discriminatória não cumprindo com a obrigação de devida diligência nos casos de violência contra a mulher. No primeiro caso, a natureza discriminatória da medida ou da política realizada é presumida e têm que ser mais bem examinadas para se verificar se são ou não razoáveis. ${ }^{68}$

No entanto, a Corte IDH observa que nem todas as desigualdades no tratamento legal são discriminatórias. Porém, a legitimidade dessa distinção depende da análise da relação de proporcionalidade entre essas distinções e os objetivos da norma legal. No relatório denominado Considerações Acerca da Compatibilidade de Medidas de Ação Afirmativa Criadas para Promover a Participação Política de Mulheres a partir dos Princípios de Igualdade e Não-Discriminação ${ }^{69}$, a CIDH observou que a identificação de um tratamento discriminatório requer a demonstração de diferença de tratamento entre pessoas em situação análoga ou comparável. Nem todo tratamento diferenciado será discriminatório e um tratamento distinto baseado em um critério razoável, como aquele relacionado ao alcance da

\footnotetext{
${ }^{67} \mathrm{CIDH}$, Relatoria Especial sobre os Direitos da Mulher. Relatório sobre Acesso à Justiça para Mulheres Vítimas de Violência nas Américas, OEA/Ser.L/V//II, 20 Janeiro, 2007. Capítulo I. p.20. para. $84-85$.

${ }^{68}$ No caso Maria Eugenia Morales, por exemplo, a distinções entre o homem e a mulher no casamento previstas em lei não era razoável, o que ensejou a aplicação do artigo 24 da Convenção para responsabilização do Estado da Guatemala. A Opinião Consultiva 04/84 estabeleceu o alcance dos artigos $1^{\circ}$ (obrigação de respeito e garantia) e 24 (direito à igualdade perante a lei) da Convenção Americana, esclarecendo que [...] o princípio da igualdade não pode ser reconciliado com a noção de que um determinado grupo tem o direito a um tratamento privilegiado. [...] É inadmissível submeter seres humanos a diferenças de tratamento que são inconsistentes com o caráter único do indivíduo.

${ }^{69}$ CIDH, Annual Report 1999, Considerations Regarding the Compatibility of Affirmative Action Measures Designed to Promote the Political Participation of Women with the Principles of Equality and Non-Discrimination, Chapter VI.
} 
justiça ou à proteção de pessoas em situação vulnerável, serve para legitimar esse tratamento diferenciado nos termos do artigo 24 da Convenção Americana. Nesta hipótese se inserem as medidas de ação afirmativa para grupo de indivíduos que merecem um tratamento diferenciado em razão do seu passado discriminatório, como as mulheres. ${ }^{70}$ Assim, como o Sistema Interamericano não proíbe a diferenciação no tratamento para possibilitar uma maior garantia de direitos e liberdades, essa diferenciação deve ser feita a partir de uma justificativa objetiva e razoável e deverá ser analisada de forma rígida a partir da inversão do ônus da prova e da presunção de invalidade. ${ }^{71}$

A adoção de normas discriminatórias e a falha dos Estados de cumprirem com as obrigações positivas previstas nos instrumentos internacionais de proteção indicam a manifestação direta de uma discriminação. No entanto, a discriminação também pode se manifestar de forma indireta, quando distinções desproporcionais e arbitrárias podem ser feitas na aplicação de leis, medidas, práticas ou políticas, que em um primeiro olhar aparentam ser neutras, mas na verdade possuem um impacto que é prejudicial para grupos em situações vulneráveis. ${ }^{72}$ Deve-se analisar o potencial impacto discriminatório, mesmo quando a norma é aparentemente neutra ou aplicável a todos os indivíduos sem distinção. ${ }^{73}$ Para ilustrar a discriminação indireta, cabe trazermos o exemplo da Corte Européia, no caso Opuz vs. Turquia ${ }^{74}$, já mencionado pela CIDH e pela Corte IDH, que determinou que por mais que a passividade judicial geral na Turquia não fosse intencional, o fato de que esta tinha um impacto discriminatório em relação às mulheres violava o direito de igual proteção dos direitos dos

\footnotetext{
${ }^{70} \mathrm{O}$ caráter compensatório dessas medidas foi confirmado pela Corte interamericana em sua Opinião Consultiva 16/99.

${ }^{71} \mathrm{CIDH}$, Relatoria Especial sobre os Direitos da Mulher. Relatório sobre Acesso à Justiça para Mulheres Vítimas de Violência nas Américas, OEA/Ser.L/V//II, 20 Janeiro, 2007. Capítulo I. p.20. para.88.

${ }^{72}$ CIDH, Relatoria Especial sobre os Direitos da Mulher. Relatório sobre Acesso à Justiça para Mulheres Vítimas de Violência nas Américas, OEA/Ser.L/V//II, 20 Janeiro, 2007. Capítulo I. p.20. para. 89-90.

${ }^{73}$ Ver CORTE IDH, Caso Girls Yean and Bosico. Sentença de 8 de setembro de 2005. para 141.

${ }^{74}$ CORTE EDH, Caso Opuz v. Turkey, Sentença de 09 de junho de 2009. para. 180, 191 e 200.
} 
indivíduos, permitia concluir que a violência doméstica sofrida pela vítima poderia ser atribuída ao Estado pelo não cumprimento do dever de garantia aos direitos das mulheres a serem livres de violência. ${ }^{75}$

A CIDH traz a posição da Corte Constitucional da Colômbia, que defende a adoção de uma dimensão substantiva e objetiva da igualdade: substantiva, porque examina se o grau de proteção recebido é desigual, quando deveria ser igual; e objetiva, pois detectado que a proteção é desigual, o Estado deve adotar ações positivas para garantir a igual proteção. ${ }^{76} \mathrm{O}$ Estado tem o dever de adotar as medidas necessárias para garantir o tratamento especial de grupos discriminados, levando em consideração as suas circunstâncias e características particulares. O comprometimento com o princípio da igualdade é mais do que a igualdade formal, na lei. Adotar somente a igualdade formal pode ter um impacto desigual para determinados grupos, resultando em uma manifestação indireta de discriminação e impedindo a realização do princípio da igualdade na prática, ou seja, nas instituições sociais, no ambiente familiar e nas instituições políticas. ${ }^{77}$

Portanto, a CIDH reconhece que o Sistema Interamericano defende a igualdade de jure, formal, ao ser bastante rígido nos critérios para adoção de tratamento diferenciado para determinados grupos de indivíduos, embora reconheça que a igualdade formal não é suficiente para atingir a igualdade de gênero. O Sistema Interamericano reconhece a importância da adoção da concepção material ou estrutural de igualdade, que tem como pressuposto o

\footnotetext{
${ }^{75}$ A Comissão se ampara também na jurisprudência da Suprema Corte do Canadá, no caso Andrews vs. Law Society of British Columbia, que estabeleceu que enquanto nem toda diferença de tratamento entre indivíduos perante a lei resulta necessariamente em desigualdade, é também verdade que o tratamento idêntico perante a lei pode, frequentemente, causar a desigualdade. $\mathrm{O}$ tratamento idêntico não é necessariamente standard para a igualdade.

${ }^{76} \mathrm{CIDH}$, Relatoria Especial sobre os Direitos da Mulher. Relatório sobre Acesso à Justiça para Mulheres Vítimas de Violência nas Américas, OEA/Ser.L/V//II, 20 Janeiro, 2007. Capítulo I. para. 94.

${ }^{77}$ CIDH, Relatoria Especial sobre os Direitos da Mulher. Relatório sobre Acesso à Justiça para Mulheres Vítimas de Violência nas Américas, OEA/Ser.L/V//II, 20 Janeiro, 2007. Capítulo I. para. 95-97.
} 
reconhecimento de que alguns setores da população requerem tratamento diferenciado para atingirem o pleno gozo de seus direitos e liberdades. ${ }^{78}$

\subsection{Discriminação de gênero e acesso à justiça: a obrigação de devida diligência e os obstáculos enfrentados por mulheres vítimas de violência}

\section{a) $O$ acesso à proteção judicial e a obrigação de devida diligência}

A análise dos principais casos analisados pela Comissão Interamericana e julgados pela Corte Interamericana, que têm como tema central a discriminação e violência baseadas em gênero, demonstram que dentre as maiores obstáculos enfrentados por mulheres vítimas de violência e outras formas de discriminação está o acesso efetivo à proteção judicial. $\mathrm{O}$ Sistema Interamericano de Proteção dos Direitos Humanos, além considerar os princípio da igualdade e não-discriminação como princípios nucleares do sistema, também estabelece que o acesso adequado e efetivo à justiça é a primeira linha para a proteção dos direitos e liberdades fundamentais, incluindo os direitos das mulheres vítimas de violência. ${ }^{79}$ Assim, o que se pretende demonstrar é que uma resposta judicial efetiva aos atos de violência praticados contra as mulheres inclui a obrigação de tornar simples, rápido, adequado e imparcial os recursos judiciais disponíveis, sem discriminação, para que os atos de violência sejam prevenidos, investigados, punidos e reparados. Insta ressaltar que presente análise dos padrões de acesso à justiça do Sistema Interamericana inclui não somente o acesso ao poder judiciário dos Estados, mas também o acesso à polícia, aos serviços de medicina forense em áreas urbanas e rurais, se a jurisdição for

\footnotetext{
${ }^{78} \mathrm{CIDH}$, Relatoria Especial sobre os Direitos da Mulher. Relatório sobre Acesso à Justiça para Mulheres Vítimas de Violência nas Américas, OEA/Ser.L/V//II, 20 Janeiro, 2007. Capítulo I. para. 98-99.
} 
nacional e local, conforme elucidado nos próprios relatórios produzidos pela Comissão Interamericana e pela Relatoria Especial sobre os Direitos da Mulher. $^{80}$

$\mathrm{O}$ acesso à justiça é definido como o acesso de jure e de facto aos órgãos judiciais e as medidas de proteção nos casos de violência, em consonância com os padrões internacionais de direitos humanos. Para que o acesso à justiça seja adequado, não basta a existência formal de mecanismos judiciais (acesso de jure); ao contrário, os mecanismos de acesso à justiça devem ser efetivos ao processarem e punirem as violações denunciadas, além de fornecerem as reparações devidas às vítimas de violência (acesso de facto). ${ }^{81} \mathrm{O}$ acesso à justiça de jure e de facto é fator essencial para erradicação da violência baseada em gênero e condição necessária para o cumprimento das obrigações assumidas pelos Estados na luta contra a discriminação de gênero.

O princípio da devida diligência pode ser aplicado em diversos contextos e de forma flexível, tendo grande importância na área dos direitos humanos, principalmente no que se refere aos direitos das mulheres a uma vida livre de violência e outras formas de discriminação. O caso Velásquez Rodríguez vs. Honduras ${ }^{82}$, julgado pela Corte Interamericana de Direitos Humanos, em 1988, serve como principal referência do conceito de devida diligência para o direito internacional dos direitos humanos. ${ }^{83}$ Este princípio serviu como guia para que a Corte pudesse determinar a extensão da

${ }^{79} \mathrm{CIDH}$, Relatoria Especial sobre os Direitos da Mulher. Relatório sobre Acesso à Justiça para Mulheres Vítimas de Violência nas Américas, OEA/Ser.L/V//II, 20 Janeiro, 2007. Capítulo I. para.6.

${ }^{80} \mathrm{CIDH}$, Relatoria Especial sobre os Direitos da Mulher. Relatório sobre Acesso à Justiça para Mulheres Vítimas de Violência nas Américas, OEA/Ser.L/V//II, 20 Janeiro, 2007. Capítulo I. para. 6-7.

${ }^{81} \mathrm{CIDH}$, Relatoria Especial sobre os Direitos da Mulher. Relatório sobre Acesso à Justiça para Mulheres Vítimas de Violência nas Américas, OEA/Ser.L/V//II, 20 Janeiro, 2007. Capítulo I. para. $1-2$.

${ }^{82}$ CORTE IDH, Caso Velásquez Rodríguez vs. Honduras. Sentença de 29 de julho de 1988. para. 172 .

${ }^{83}$ ABI-MERSHED, Elizabeth, Due Diligence and the Fight against Gender Based Violence in the Inter- American System. IN: BENNINGER-BUDEL, Carin (Org). Due Diligence and its Application to Protect Women from Violence. Netherlands: Martinus Nijhoff Publishers, 2008. p. $129-130$. 
responsabilidade estatal pelas violações de direitos sob o âmbito da sua jurisdição, que pode se originar não somente de atos praticados por agentes estatais, mas também por particulares. ${ }^{84}$ Neste caso, a Corte IDH estabeleceu que a responsabilidade do Estado de agir com devida diligência para prevenir, investigar e sancionar violações de direitos humanos não se esgota nas hipóteses em que a violação ocorreu por um ato do poder público ou por um ato de pessoas que atuam investidas da autoridade estatal; uma violação, mesmo que não possa ser imputada diretamente ao Estado, por ser obra de um particular ou por não se ter identificado o autor da violação, pode ensejar a responsabilidade do Estado, não pelo fato em si mesmo, mas pelo Estado não ter atuado segundo o princípio da devida diligência para prevenir a violação ou por não respondê-lo conforme previsto na Convenção Americana. ${ }^{85}$ A violação pode ser atribuída ao Estado, mesmo que a identidade do responsável não seja conhecida, desde que esteja comprovado que a violação ocorreu como a aquiescência do Estado, ou se o Estado, ciente do risco de violação, permitiu que ela ocorresse, sem tomar as medidas para preveni-las ou para punir os responsáveis. ${ }^{86}$

\footnotetext{
${ }^{84}$ ABI-MERSHED, Elizabeth, Due Diligence and the Fight against Gender Based Violence in the Inter- American System. IN: BENNINGER-BUDEL, Carin (Org). Due Diligence and its Application to Protect Women from Violence. Netherlands: Martinus Nijhoff Publishers, 2008. p. 129-130.

${ }^{85}$ No caso Massacre Mapiripán, a Corte decidiu, como forma de fortalecer os standards de proteção, que "a responsabilidade internacional do Estado deve envolver os atos praticados por particulares que não são, em princípio, atribuídos ao Estado. Os efeitos da obrigação erga omnes do Estados de agir com devida diligência se estendem para além da relação entre agentes estatais e indivíduos sob a sua jurisdição; seus efeitos se manifestam na obrigação positiva que os Estados possuem de adotar todas as medidas necessárias para garantir a proteção efetiva dos direitos humanos nas relações interpessoais [...]"Outra decisão da Corte elaborada sobre esse standard de atribuição de responsabilidade é o julgamento do caso Massacre de Pueblo Bello, em que se estabeleceu que a obrigação erga omnes do Estado de garantir os direitos previstos na Convenção não implica a responsabilidade estatal indiscriminada por qualquer ato praticado por indivíduos privados. (Ver CORTE IDH, Caso "Massacre Mapiripán" vs. Colombia. Sentença de 15 de novembro de 2005. Series C No. 134, para. 111; Caso Massacre de Pueblo Bello vs. Colombia. Sentença de 31 de janeiro de 2006. Series C No. 140, para. 123).

${ }^{86}$ A obrigação dos Estados de prevenir danos e proteger os indivíduos particulares em suas relações depende se o Estado tinha conhecimento do perigo real e presente de violação de direito, e se havia uma chance razoável de prevenir ou evitar essa violação. A Corte IDH segue o entendimento da Corte EDH no caso Osman vs. Reino Unido, em que se foi esclarecido que o Estado só incorrerá em responsabilidade internacional por atos cometidos por terceiros quando ficar demonstrado que o Estado tinha conhecimento de risco real e imediato de violação de um direito e falhou ao adotar as medidas para evitá-lo. (Ver CORTE EDH, Osman vs. Reino Unido, Sentença de 28 de outubro de 1998. para. 115- 116).
} 
Os princípios gerais do sistema regional e o princípio da eficácia requerem, portanto, que os direitos e liberdades dos indivíduos sejam respeitados e garantidos pelos Estados. Caso o exercício de algum desses direitos esteja comprometido, o Estado dever tomar todas as medidas internas necessárias para que os indivíduos sob a sua jurisdição possam gozar plenamente de seus direitos, de acordo com o previsto no artigo $2^{\circ}$ da Convenção Americana. Nesse sentido, o dever dos Estados de fornecerem mecanismos judiciais que possam garantir e reparar direitos violados inclui não somente a existência formal desses mecanismos, através da previsão da sua legal e constitucional, mas o seu funcionamento efetivo, apto a garantir direitos, a punir violações e a fornecer reparações. ${ }^{87}$

Os obstáculos enfrentados pelas mulheres para terem acesso efetivo aos mecanismos judiciais existentes são consequências dos mesmos padrões discriminatórios que buscam justificar os atos de violência de gênero perpetrados. A discriminação, portanto, se relaciona intimamente com a violência baseada em gênero perpassando desde o contexto desigual e discriminatório que fundamenta esses atos até o não cumprimento da obrigação positiva dos Estados de atuar com devida diligência para prevenir, investigar, punir e reparar a violência de gênero. A Comissão Interamericana estabeleceu no caso Maria da Penha vs. Brasil ${ }^{88}$ a presença geral de um padrão de tolerância do Estado nos casos de violência doméstica e a ausência de efetividade do poder judiciário no julgamento desses casos. Segundo o estabelecido pela Comissão Interamericana em seus relatórios de mérito, entre as principais obrigações que os Estados devem cumprir estão: (i) o dever de erradicar de maneira rápida e eficaz os atos de violência contra as mulheres cometidos pelo Estado e pelos agentes não-estatais; (ii) o dever de proporcionar soluções eficazes e imparciais

${ }^{87} \mathrm{CIDH}$, Relatoria Especial sobre os Direitos da Mulher. Relatório sobre Acesso à Justiça para Mulheres Vítimas de Violência nas Américas, OEA/Ser.L/V//II, 20 Janeiro, 2007. Capítulo I. para. 26.

${ }^{88}$ CIDH, Mérito, No 54/01, Maria da Penha Fernandes (Brasil). Abril 16, 2001. 
para as vítimas da violência; (iii) e a obrigação de tomar medidas para erradicar a discriminação contra as mulheres e os padrões estereotipados de comportamento em suas sociedades.

No que se refere ao dever de adotar medidas apropriadas para garantir o direito das mulheres a uma vida livre de violência, previsto no artigo $7^{\circ}$ da Convenção de Belém do Pará, que inclui a obrigação de adotar medidas legislativas, devida à relação direta existente entre discriminação e violência, o artigo 7.b da Belém do Pará deve ser interpretado com uma obrigações dos Estados de alterar leis discriminatórias, práticas e políticas públicas ou qualquer outra norma que, mesmo que neutra, tenha como efeito prático a discriminação contra as mulheres. ${ }^{89}$ A Convenção de Belém do Pará reconhece a relação existente entre o acesso adequado à justiça e a eliminação da violência de gênero e da discriminação que a perpetua, ao estabelecer as obrigações do Estado de agir com devida diligência em seu artigo $7^{\circ}$.

Ainda em relação à obrigação de devida diligência para prevenir os atos de violência, a Comissão Interamericana estabelece outro padrão de atribuição de responsabilidade estatal ao impor aos Estados outro dever paralelo a essa obrigação. Segundo a Comissão "de um lado, os Estados devem monitorar a situação social através da produção de dados estatísticos adequados para a concepção e avaliação de políticas públicas. De outro lado, os Estados devem ter em conta as políticas implementadas pela sociedade civil. ${ }^{90}$ A obrigação assumida no artigo $7 . b$ da Convenção de Belém do Pará deve ser lida em conjunção com a obrigação estabelecida no artigo 8.h para garantir que as estatísticas e outros dados relevantes sobre as causas, consequiências e incidência da violência contra as mulheres sejam investigadas e compilado com o objetivo de avaliar a eficácia das medidas

\footnotetext{
${ }^{89} \mathrm{CIDH}$, Relatoria Especial sobre os Direitos da Mulher. Relatório sobre Acesso à Justiça para Mulheres Vítimas de Violência nas Américas, OEA/Ser.L/V//II, 20 Janeiro, 2007. Capítulo I. para. 101.

${ }^{90} \mathrm{CIDH}$, Relatoria Especial sobre os Direitos da Mulher. Relatório sobre Acesso à Justiça para Mulheres Vítimas de Violência nas Américas, OEA/Ser.L/V//II, 20 Janeiro, 2007. Capítulo I. para. 42.
} 
para prevenir, punir e erradicar a violência contra as mulheres e, em seguida, formular e introduzir as alterações necessárias". Os dados estatísticos nas questões relacionadas à violência contra a mulher são um mecanismo público importante e devem ser divulgados de maneira ampla visando encorajar o debate público e incentivar a adoção de políticas públicas. $^{91}$

Outro importante padrão de acesso à justiça apresentado pela Comissão indica que o artigo 7.d da Convenção de Belém do Pará, que estabelece que os Estados devem adotar as medidas jurídicas necessárias que impeçam o agressor de perseguir, intimidar, ou pôr em perigo a vida da vítima, deve ser interpretado como uma das dimensões da obrigação de garantir o acesso adequado à justiça e aos mecanismos de proteção judicial prevista no artigo 25 da Convenção Americana. O artigo 8.d da Convenção de Belém do Pará estabelece algumas dos elementos do tipo de medidas protetivas que o Estado deve fornecer às mulheres vítimas de violência, como abrigos, serviços de aconselhamento para toda a família e cuidado e custódia para seus filhos que também foram afetados. ${ }^{92}$

\section{b) Obstáculos para acesso à justiça: ineficácia e impunidade nos casos de violência contra as mulheres}

Os principais relatórios produzidos pela CIDH e pela Relatoria Especial sobre os Direitos das Mulheres, além dos casos tramitados no Sistema Interamericano, revelam que apesar da existência formal de políticas e leis que visam combater a discriminação e violência baseadas em gênero, os sistemas de justiça dos Estados vêm respondendo de forma deficiente aos atos de violência contra as mulheres. Além da discriminação

\footnotetext{
${ }^{91} \mathrm{CIDH}$, Relatoria Especial sobre os Direitos da Mulher. Relatório sobre Acesso à Justiça para Mulheres Vítimas de Violência nas Américas, OEA/Ser.L/V//II, 20 Janeiro, 2007. Capítulo I. para. 42.

${ }^{92} \mathrm{CIDH}$, Relatoria Especial sobre os Direitos da Mulher. Relatório sobre Acesso à Justiça para Mulheres Vítimas de Violência nas Américas, OEA/Ser.L/V//II, 20 Janeiro, 2007. Capítulo I. para. 56.
} 
de gênero que se revela nos atos de violência perpetrados, as mulheres têm que também enfrentar a discriminação de gênero que se manifesta dentro da própria administração da justiça, e que impede que os casos de violência contra a mulher sejam efetivamente investigados, processados, punidos e reparados, fortalecendo a aceitabilidades dessas práticas pela sociedade e o sentimento de insegurança das mulheres em face dos mecanismos de acesso à justiça.

Os principais obstáculos identificados pela Comissão Interamericana, que serão abordados nos tópicos seguintes, são: (i) a discriminação das autoridades responsáveis pela condução das investigações e processamentos dos crimes de violência contra a mulher e a conseqüente falta de sensibilidade e preparo para lidar com questões relacionadas ao gênero; (ii) a revitimização sofrida pelas mulheres vítimas quando tentam relatar as agressões sofridas; (iii) ausência de proteção e garantias judiciais para salvaguardar sua segurança, dignidade e privacidade; (iv) custos financeiros dos procedimentos judiciais; (v) localização geográfica dos órgãos judiciais; (vi) e ausência de informação disponível para mulheres vítimas de violência e para seus familiares sobre os procedimentos adequados para garantir o processamento dos atos de violência praticados. ${ }^{93}$ Além da abordagem das principais dificuldades mencionadas, buscar-se-á apresentar as recomendações da Comissão Interamericana aos Estados para que eles possam superar as deficiências apontadas, a fim de garantir o pleno acesso à justiça para mulheres vítimas de violência.

\footnotetext{
93 A Comissão revela o resultado de algumas pesquisas realizadas em quatro países da região Chile, Guatemala, Honduras e Equador, que identificam algumas razões da justiça ser tão pouco utilizada em casos de violência contra a mulher, principalmente nos casos de violência física e sexual. São elas: a natureza desses crimes; as atitudes sociais em relação a eles; o modo como as autoridades reagem a esses casos; o ambiente em que as denúncias são apresentadas; o critério para determinar quais crimes serão processados; o modo em que as investigações são conduzidas; o fato de que as mulheres vítimas não possuem ninguém para defendê-las ou darem suporte; as dificuldades encontradas para o acesso às instituições; a vulnerabilidade das mulheres vítimas dentro do sistema; ausência de resposta efetiva quando relatam a violência sofrida; a duração injustificada do processo, dentre outras.Ver CIDH, Relatoria Especial sobre os Direitos da Mulher. Relatório sobre Acesso à Justiça para Mulheres Vítimas de Violência nas Américas, OEA/Ser.L/V//II, 20 Janeiro, 2007. Capítulo II. para.
} 


\section{b.1) Deficiências na fase investigatória}

A análise da efetividade dos sistemas de justiça dos Estados-Partes se aplica a todo procedimento em consideração, incluindo a fase de investigações das violações de direitos humanos. As garantias do artigo 8.1 da Convenção não somente se aplicam ao acesso a juízes e tribunais judiciais, mas também se refere às autoridades competentes para condução das investigações, como a polícia e o Ministério Público, uma vez que início ou desenvolvimento da fase processual têm como pressuposto os resultados obtidos na fase investigatória. ${ }^{94}$ As ausências de medidas internas necessárias para que as investigações sejam realizadas de forma eficiente frente aos casos de violência, em consonância com a obrigação de devida diligência, ensejam também a violação do artigo $2^{\circ}$ da Convenção Americana e do artigo 7.c da Convenção de Belém do Pará. ${ }^{95}$

A deficiência na fase de investigação representa a maior falha dos Estados no cumprimento das medidas positivas que devem ser adotadas para garantir o direito das mulheres a uma vida livre de violência e o maior obstáculo para que elas alcancem o acesso efetivo à justiça. ${ }^{96} \mathrm{~A}$ investigação, que se insere, portanto, em uma das obrigações de garantia do Estado para cumprir com a sua obrigação de devida diligência, é uma importante fase nos casos de violência contra a mulher e deve ser realizada de forma imediata, exaustiva, séria e imparcial, além de dever ser conduzida por agentes devidamente treinados para lidar com questões de gênero. ${ }^{97} \mathrm{~A}$ investigação, como a prevenção, é uma obrigação de meio, e não de resultado, e não dever ser compreendida como mera formalidade,

\footnotetext{
${ }^{94}$ CORTE IDH, Caso Fernández Ortega y Otros vs. México. Sentença de 30 de agosto de 2010. para. 175.

${ }_{95}$ CORTE IDH, Caso González y Otras (“Campo Algodonero") vs. México. Sentença de 16 de novembro de 2009. para. 388.

${ }^{96}$ Ver CORTE IDH, Caso González y Otras ("Campo Algodonero") vs. México. Sentença de 16 de novembro de 2009; CORTE IDH, Caso Fernández Ortega y Otros vs. México. Sentença de 30 de agosto de 2010; CORTE IDH, Caso Rosendo Cantu y Otra vs. México. Sentença de 31 de agosto de 2010.
} 
condenada a ser infrutífera. ${ }^{98}$ Ao contrário, deve ser entendida como uma obrigação legal dos Estados que deve ser cumprida de maneira efetiva, sem discriminação, objetivando a identificação do agressor e o subseqüente processamento dos atos de violência perpetrados. Caso contrário, a investigação será prejudicada, evidências serão perdidas, o que poderá comprometer os futuros procedimentos do caso e a consequente punição do agressor.

Através do estudo dos casos individuais analisados pela $\mathrm{CIDH}$, podemos identificar alguns exemplos de falha dos Estados na obrigação de investigação. No caso Maria da Penha vs. Brasil, a CIDH responsabilizou o estado brasileiro por ter prolongado a investigação da violência doméstica alegada pela vítima por mais de 17 anos. Já no caso irmãs González Pérez vs. México ${ }^{99}$, as irmãs Ana, Beatriz e Cecília, pertencentes à comunidade nativa Tzeltal, foram detidas ilegalmente, torturadas e estupradas por militares mexicanos. ${ }^{100}$ As investigações foram transferidas para os tribunais militares, que não investigaram os casos com a imparcialidade necessária de acordo o princípio do devido processo legal. A partir dessa análise, a Comissão reafirmou um princípio básico de direitos humanos, já estabelecido no caso Raquel Martín de Mejía vs. Peru ${ }^{101}$, particularmente pertinente nos casos envolvendo violência baseada em gênero, que é a obrigação dos Estados de conduzirem suas investigações por autoridades competentes e imparciais, treinadas e sensíveis às questões de gênero, sob

\footnotetext{
${ }^{97}$ Ver CIDH, Relatoria Especial sobre os Direitos da Mulher. Relatório sobre Acesso à Justiça para Mulheres Vítimas de Violência nas Américas, OEA/Ser.L/V//II, 20 Janeiro, 2007. Capítulo II. para. 132.

${ }_{98}$ CORTE IDH, Caso Velásquez Rodríguez vs .Honduras. Sentença de 29 de julho de 1988. para. 176-177.

${ }^{99}$ CIDH, Mérito, № 53/01, Ana, Beatriz e Cecilia González Pérez (México). Abril 4, 2001. para. 88.

${ }^{100}$ A Comissão Interamericana reconheceu que a dor e a humilhação pela violência sexual sofrida foram agravadas pelo fato de serem mulheres indígenas que não conheciam a língua de seus agressores e das autoridades envolvidas no processo, e pela discriminação que sofreram pela própria comunidade indígena em razão da natureza da violência cometida contra elas. Ver CIDH, Mérito, № 53/01, Ana, Beatriz e Cecilia González Pérez (México). Abril 4, 2001. para. 95.

${ }^{101}$ CIDH, Mérito, № 5/96, Raquel Martín de Mejía (Peru). Março 1, 1996.
} 
pena do fracasso das investigações, comprometendo o trâmite do caso. ${ }^{102}$ Nas palavras da Comissão, "o direito a um recurso estabelecido no artigo 25, interpretado em conjunção com a obrigação do artigo 1.1 e do artigo 8.1, deve ser interpretado como o direito do indivíduo a ter acesso a um tribunal quando qualquer dos seus direitos tiver sido violado, para obter uma investigação judicial conduzida por agentes competentes, imparciais e independente, que irão decidir se houve ou não uma violação de direito, e irão estabelecer, se apropriado, uma adequada compensação". ${ }^{103}$ No caso Raquel Martín de Mejía, a vítima, estuprada por um chefe do grupo armado que vestia uniforme do exército peruano, não submeteu o seu caso perante as autoridades nacionais, após identificar que os atos de violência sexual praticados por membros das forças armadas não são investigados de forma imparcial, uma vez que, em determinadas áreas a autoridades responsáveis pela investigação e processamento desses crimes são as mesmas que praticaram as violações. ${ }^{104}$

A Comissão Interamericana observa que são vários os fatores que conspiram para ineficácia das investigações nos casos de violência contra a mulher: (i) o atraso prolongado das investigações; (ii) incompetência e imparcialidade das autoridades que conduzem as investigações; (iii) ênfase na evidência física e na prova testemunhal; (iv) ausência de credibilidade nas alegações das vítimas; (v) e tratamento inapropriado das mulheres vítimas e de seus familiares. Todos os fatores apresentados se relacionam intimamente com padrões sociais discriminatórios que fazem com que as

\footnotetext{
102 Outro ponto de enorme relevância no caso Raquel Martín de Mejía (Peru) foi o desenvolvimento do conceito de estupro como ato de tortura e como uma forma de violação ao direito à vida privada da mulher. Este entendimento também será confirmado pela Comissão no caso das irmãs González Pérez (México).

${ }^{103}$ CIDH, Mérito, No 5/96, Raquel Martín de Mejía (Peru). Março 1, 1996. para.22.

104 A Human Rights Watch observou que apesar dos incidentes de estupro serem largamente difundidos no Peru, são poucos os membros das forças armadas que são punidos pelos atos de violência praticados, mesmo quando os casos são conduzidos por autoridades apropriadas. Ao contrário, o que se demonstra é que as forças armadas protegem os supostos responsáveis pelas violações, em troca de promoções e benefícios profissionais, tolerando o cometimento desses crimes. A legislação prevê que os crimes praticados no "exercício da função" devem ser julgados pela justiça militar, tornando praticamente impossível a responsabilização de oficiais militares pelos atos de violência sexual praticados contra as mulheres.
} 
autoridades considerem os casos de violência contra a mulher como não prioritários, ocasionando a impunidade dessas práticas. ${ }^{105}$

Além das violações apontadas, outra irregularidade padrão nos casos de violência contra mulher é a ausência de produção das principais provas necessárias para esclarecer a verdade do crime e identificar o agressor. Os esforços das investigações têm como cerne a busca por evidências físicas e por testemunhas, negligenciando outros tipos de prova que podem ser cruciais nesses casos, como as evidências de natureza psicológica. ${ }^{106}$ Os casos de violência sexual merecem particular análise acerca da obrigação de investigar e punir essas violações. A Corte Européia de Direitos Humanos estabeleceu que a efetiva investigação e punição de casos de agressão sexual devem levar em consideração tanto o corpo de evidências quanto o contexto em que ocorreu a agressão, e não confiná-los a evidência direta de resistência física da vítima. No caso M.C vs. Bulgária ${ }^{107}$, a Corte Européia considerou a responsabilidade estatal, porque o Estado arquivou uma investigação criminal de estupro de uma menina de 14 anos, em razão da não evidência do uso da força e de sinais de resistência física. A investigação nos casos de violência sexual, principalmente nos casos de menores, deve se assentar na questão do não-consentimento e em todas as circunstâncias que podem ter evitado a resistência física da vítima, como a vulnerabilidade de uma menor nos casos de estupro e o ambiente de coerção criado pelo agressor; e não em provas físicas e diretas do crime sexual, como traços de violência e testemunhas. ${ }^{108}$ A cultura da vítima e o contexto em que a agressão ocorreu também devem ser levados em conta. A

\footnotetext{
${ }^{105}$ Ver CIDH, Relatoria Especial sobre os Direitos da Mulher. Relatório sobre Acesso à Justiça para Mulheres Vítimas de Violência nas Américas, OEA/Ser.L/V//II, 20 Janeiro, 2007. Capítulo II. para. 132

${ }^{106}$ A CIDH, em seu Relatório sobre Violência e Discriminação contra a Mulher no Conflito Armado na Colômbia, expressou preocupação com a chamada "chain of custody", nos casos envolvendo violência contra mulher e a ênfase dada às provas de natureza física. Segundo a Comissão, "chain of custody" é um conjunto de procedimentos que as autoridades encarregadas do caso devem seguir visando preservar as provas até que elas possam ser utilizadas em julgamento.

${ }^{107}$ Corte EDH, M.C. vs. Bulgária, sentença de 04 de março de 2004. para.178-184

${ }^{108}$ CIDH, Relatoria Especial sobre os Direitos da Mulher. Relatório sobre Acesso à Justiça para Mulheres Vítimas de Violência nas Américas, OEA/Ser.L/V//II, 20 Janeiro, 2007. Capítulo I. para. 51.
} 
consideração da vida sexual da vítima também é inadmissível. A Comissão Interamericana salienta que instrumentos internacionais apresentam um conjunto de procedimentos que devem ser seguidos nos casos de mulheres vítimas de violência. As Regras de Procedimento e Provas da Corte Criminal Internacional indica medidas específicas de gênero que devem ser tomadas para possibilitar que vítimas de violência sexual participem e testemunhem em todas as etapas do procedimento, tendo pleno acesso a todas as informações do processo. ${ }^{109} \mathrm{O}$ Manual para Investigação Efetiva $e$ para Documentação de outros Tratamentos Cruéis, Desumanos ou Degradantes $^{110}$ e as Medidas para Prevenção de Crime e para Justiça Criminal para Eliminar a Violência contra as Mulheres ${ }^{111}$, ambos do âmbito ONU, estabelecem a importância de preservar o bem-estar de vítimas durante as etapas de procedimento criminal, que inclui a fase de investigação. A Comissão Interamericana esclarece que pode invocar esse princípio nos casos de violência contra a mulher para evitar a revitimização das mulheres durante esse período, reconhecendo a sua vulnerabilidade nesses casos, principalmente nos casos de violência sexual. As mulheres, normalmente, não possuem um espaço reservado para narrar a violência sofrida, sendo obrigadas a fazer suas alegações em ambientes abertos, como a presença de vários funcionários, que muitas vezes não possuem relação com a investigação do crime.

\footnotetext{
109 United Nations, International Criminal Court, Rules of Procedure and Evidence, U.N. Doc. PCNICC/2000/1/Add.1 (2000), Rule 70. The Rule provides that: In cases of sexual violence, the Court shall be guided by and, where appropriate, apply the following principles: (a) Consent cannot be inferred by reason of any words or conduct of a victim where force, threat of force, coercion or taking advantage of a coercive environment undermined the victim's ability to give voluntary and genuine consent; ( $b$ Consent cannot be inferred by reason of any words or conduct of a victim where the victim is incapable of giving genuine consent; (c) Consent cannot be inferred by reason of the silence of, or lack of resistance by, a victim to the alleged sexual violence; (d) Credibility, character or predisposition to sexual availability of a victim or witness cannot be inferred by reason of the sexual nature of the prior or subsequent conduct of a victim or witness.

${ }^{110}$ United Nations, United Nations Principles on the Effective Investigation and Documentation of Torture and Other Cruel, Inhuman or Degrading Treatment or Punishment, United Nations General Assembly Resolution 55/89, December 4, 2000, U.N. Doc. A/RES/55/89, para. 6(a).

${ }^{111}$ United Nations, Crime Prevention and Criminal Justice Measures to Eliminate Violence against Women, Resolution approved by the United Nations General Assembly, A/RES/52/86, February 2, 1998, Annex, Section II.
} 
O exame do Relatório produzido pela Comissão sobre Violência e Discriminação contra Mulher no Conflito Armado da Colômbia ${ }^{112}$ revela como os padrões discriminatórios podem influenciar na decisão dos promotores sobre quais crimes relacionados à violência contra a mulher eles irão investigar. As opiniões das autoridades, muitas vezes discriminatórias ou insensíveis às questões de gênero, acabam tendo um papel determinante no processamento dos crimes. As autoridades costumam ignorar as provas de natureza psicológica e também a vulnerabilidade das vítimas que, muitas vezes, não conseguem contribuir com as investigações por temerem represálias dos agressores ou o preconceito da sociedade e das próprias autoridades envolvidas. ${ }^{113}$

Essa ampla discricionariedade, em razão da aplicação incorreta do princípio da oportunidade, faz com que os promotores apenas prossigam com as investigações quando acreditam que há provas inequívocas que garantirão a condenação, concedendo maior importância às evidências dos casos e à conseqüente vitória da denúncia, do que à seriedade das questões de gênero envolvidas. ${ }^{114}$ A vitória nos casos de violência sexual, por exemplo, não é certa. Os crimes de natureza sexual possuem natureza diversa de outros crimes, e são fortemente caracterizados por padrões discriminatórios, desde a sua execução até o seu processamento pela administração da justiça. A ênfase na garantia de sucesso na condenação desses crimes impede que casos de violência sexual contra a mulher sejam

${ }^{112}$ CIDH, Relatoria Especial sobre os Direitos da Mulher. Relatório sobre Violência e Discriminação contra a Mulher no Conflito Armado na Colômbia, OEA OEA/Ser.L/V/II, 18 de outubro, 2006. Capítulo V.

${ }_{113}$ CIDH, Relatoria Especial sobre os Direitos da Mulher. Relatório sobre Violência e Discriminação contra a Mulher no Conflito Armado na Colômbia, OEA OEA/Ser.L/V/II, 18 de outubro, 2006. Capítulo V. para. 205-206.

${ }^{114} \mathrm{CIDH}$, Relatoria Especial sobre os Direitos da Mulher. Relatório sobre Violência e Discriminação contra a Mulher no Conflito Armado na Colômbia, OEA OEA/Ser.L/V/II, 18 de outubro, 2006. Capítulo V. para. 213; CIDH, Relatoria Especial sobre os Direitos da Mulher. Relatório sobre Acesso à Justiça para Mulheres Vítimas de Violência nas Américas, OEA/Ser.L/V//II, 20 Janeiro, 2007. Capítulo II. para. 145-146. 
processados, e que a justiça criminal possa evoluir no julgamento desses atos. ${ }^{115}$

A imparcialidade e independência das autoridades na condução das investigações também devem ser respeitadas para garantir a efetividade do acesso à justiça. Nos casos de atos de violência praticados por oficiais militares contra mulheres indígenas, rurais e em regiões de conflito armado, muitas vezes as autoridades responsáveis pelas investigações são também aquelas que figuram como possíveis perpetradores dos atos de violência. Este fato fica claramente demonstrado nos casos em que a justiça militar é responsável pela condução das investigações de crimes de violência praticados por militares, sob a alegação de que o crime foi cometido no exercício da sua função. ${ }^{116}$

Em relação às recomendações aos Estados no que tange à obrigação de investigar, a Comissão Interamericana destaca como as principais medidas a serem tomadas pelo Estado: (i) desenvolver a capacidade das instituições para combater o padrão de impunidade em casos envolvendo violência contra mulher, através de investigações criminais efetivas que sejam capazes de levar casos a julgamento, garantindo assim que estes crimes sejam punidos e reparados; (ii) aumento de recursos humanos e financeiros para combater a impunidade desses crimes, como a aquisição dos equipamentos técnicos necessários para fazer testes químicos e forenses e para compilar todos os elementos necessários para resolver o caso sob investigação; (iii) garantir que os agentes públicos envolvidos na investigação sejam propriamente educados sobre os direitos das mulheres

\footnotetext{
${ }^{115} \mathrm{CIDH}$, Relatoria Especial sobre os Direitos da Mulher. Relatório sobre Acesso à Justiça para Mulheres Vítimas de Violência nas Américas, OEA/Ser.L/V//II, 20 Janeiro, 2007. Capítulo II. para. 146

116 A Corte Interamericana estabeleceu nos casos Rosendo Cantú e Outra vs. México e Fernández Ortega e Outros vs. México que "a violência sexual de uma pessoa por parte de um oficial militar não guarda, em nenhum caso, relação com a disciplina ou missão militar. Ao contrário, o ato cometido por militares contra a vítima afetou bens jurídicos tutelados pela Convenção Americana. Esta conduta é claramente contrária aos deveres de respeito e garantia dos direitos humanos e, portanto, está excluída da competência da jurisdição militar." Ver CORTE IDH, Caso Fernández Ortega y Otros vs. México. Sentença de 30 de agosto de 2010. para. 177.
} 
previstos em documentos nacionais e internacionais; tomar as medidas necessárias para institucionalizar a colaboração e informação entre as autoridades responsáveis pela investigação de atos de violência e discriminação, particularmente entre promotores públicos e a polícia; (iv) organizar sistematicamente as decisões tomadas na investigação e processamento de casos envolvendo violência contra as mulheres, e tornar essas informações acessíveis para os agentes públicos dos órgãos judiciais locais e nacionais; (v) e criar protocolos para facilitar e promover a investigação efetiva e transparente de casos em que haja a ocorrência de violência física, psicológica e sexual, o que inclui a descrição detalhada das provas mínimas que são requeridas para substanciar um caso: provas científicas, físicas, psicológicas e testemunhais, incentivando a investigação multidisciplinar nesses casos. ${ }^{117}$

\section{b.2) Deficiências no trâmite judicial}

As deficiências nos casos de violência contra a mulher não se restringem à fase de investigações, mas se estendem pela fase de processamento e punição desses crimes. Os padrões discriminatórios que influenciam a conduta das autoridades responsáveis pela condução da fase investigatória, afetam também as autoridades do poder judiciário responsáveis pelo processamento das práticas de violência baseadas em gênero. ${ }^{118}$ Os valores sócio-culturais, que se baseiam na ideia de inferioridade e subordinação das mulheres, dificultam o convencimento dos juízes nos casos de violência contra a mulher, resultando, muitas vezes, na descaracterização das mulheres como vítimas para responsabilizá-las pelos crimes praticados, que permanecem impunes. A aceitação da dominação masculina e a socialização da violência e da discriminação contra a mulher

\footnotetext{
${ }^{117}$ CIDH, Relatoria Especial sobre os Direitos da Mulher. Relatório sobre Acesso à Justiça para Mulheres Vítimas de Violência nas Américas, OEA/Ser.L/V//II, 20 Janeiro, 2007. Capítulo IV.

${ }^{118} \mathrm{CIDH}$, Relatoria Especial sobre os Direitos da Mulher. Relatório sobre Acesso à Justiça para Mulheres Vítimas de Violência nas Américas, OEA/Ser.L/V//II, 20 Janeiro, 2007. Capítulo II, para. 147.
} 
fazem com que as autoridades tratem essas violações como comportamentos comuns dentro da estrutura social, que não merecem ser processados, portanto. ${ }^{119}$ Os papéis sociais estereotipados atribuídos a homens e mulheres são utilizados para justificar atos de violência, como costuma ocorrer nos casos de violência sexual, em que a mulher, compreendida como objeto sexual, acaba sendo muitas vezes responsabilizada pelos atos de violência praticados pelos agressores, ou nos casos de violência doméstica, em que o papel de provedor e responsável pela ordem familiar assumido pelos homens serve para justificar os atos de violência praticados contra a sua companheira. Os casos de violência doméstica também revelam que os magistrados continuam considerando essas práticas como restritas ao âmbito privado, crimes não prioritários, que podem ser resolvidos exclusivamente pelos membros da família envolvidos, sem que seja necessária uma atuação estatal específica para solucioná-los. Esse entendimento discriminatório acerca dos casos de violência doméstica fica claramente demonstrado no caso Maria da Penha vs. Brasil, que ensejou a responsabilizado do estado brasileiro pela ausência de efetividade no processamento e punição dos atos de violência doméstica que estavam sendo praticados pelo companheiro da vítima durante anos, em razão da existência de um padrão discriminatório que resultava na ineficácia do poder judiciário brasileiro no processamento e punição dos casos de violência doméstica. ${ }^{120}$

O posicionamento das autoridades competentes - homens e mulheres para julgar os casos de violência contra a mulher é caracterizado por um sentimento de hostilidade e incredulidade em relação às mulheres vítimas e de insensibilidade em face das questões relacionadas à discriminação de

\footnotetext{
${ }^{119} \mathrm{CIDH}$, Relatoria Especial sobre os Direitos da Mulher. Relatório sobre Acesso à Justiça para Mulheres Vítimas de Violência nas Américas, OEA/Ser.L/V//II, 20 Janeiro, 2007. Capítulo II, para. 150.

${ }^{120} \mathrm{CIDH}$, Relatoria Especial sobre os Direitos da Mulher. Relatório sobre Acesso à Justiça para Mulheres Vítimas de Violência nas Américas, OEA/Ser.L/V//II, 20 Janeiro, 2007. Capítulo II, para. 149-151.
} 
gênero. ${ }^{121}$ O Relatório da CIDH sobre a Situação dos Direitos da Mulher na Ciudad Juárez, México: o direito a não ser objeto de violência e discriminação revela que as autoridades costumam questionar as vítimas sobre o tempo que costumavam gastar fora de casa, sobre suas experiências sexuais, sobre o comprimento das roupas que costumam vestir ou que vestiam no momento do crime, se eram prostitutas ou se costumavam ser "fáceis" com os homens. O comportamento discriminatório das autoridades dificulta o acesso à justiça por mulheres vítimas de violência, que temem serem estigmatizadas ou culpadas pela violência que sofreram. ${ }^{122}$ Além disso, as autoridades costumam interpretar o fato das mulheres desistirem de dar prosseguimento ao processo, como casos em que os crimes relatados não eram dignos de serem processados ou como casos em que a veracidade das informações poderia ser questionada, sem atentarem para as razões que podem ter ensejado esse comportamento, como a ameaça do agressor, a dependência econômica ou o temor de revitimização durante o processo. ${ }^{123}$

Os casos M.M vs. Peru ${ }^{124}$ e M.Z vs. Bolivia ${ }^{125}$, resolvidos na Comissão Interamericana através de solução amistosa, têm especial relevância para análise do tratamento discriminatório desempenhado pelas autoridades na fase de trâmite judicial de crimes de violência contra mulher, principalmente, em relação à consideração e à interpretação de provas relevantes ao processo nos crimes de natureza sexual. No caso M.M, o agressor da vítima, que a estuprou durante uma consulta médica, foi absolvido sob a justificativa de que os fatos a ele imputados não foram comprovados de forma irrefutável, já que a suposta vítima não havia sustentado de maneira clara e precisa a sua acusação de abuso sexual, e que

\footnotetext{
${ }^{121} \mathrm{CIDH}$, Relatoria Especial sobre os Direitos da Mulher. Relatório sobre Acesso à Justiça para Mulheres Vítimas de Violência nas Américas, OEA/Ser.L/V//II, 20 Janeiro, 2007. Capítulo II, para. 154.

122 CIDH, Relatoria Especial sobre os Direitos da Mulher. Relatório sobre a Situação dos Direitos da Mulher na Cidade de Juárez, México: o Direito a não ser objeto de Violência e Discriminação, OEA/Ser.L/V/II.117, 7 Março, 2003. para. 4.

${ }^{123} \mathrm{CIDH}$, Relatoria Especial sobre os Direitos da Mulher. Relatório sobre Violência $e$ Discriminação contra a Mulher no Conflito Armado na Colômbia, OEA OEA/Ser.L/V/II, 18 de outubro, 2006. Capítulo V. para. 216.

${ }^{124}$ CIDH, Solução Amistosa, caso 12.041, M.M (Peru). Março 17, 2000.
} 
os certificados médicos legais afirmavam que a vítima apresentava “defloração antiga”. Assim, em caso de dúvida e desconfiança da vítima, a decisão deveria favorecer o processado em virtude do princípio de in dúbio pro reo. ${ }^{126}$ No caso de $M . Z$, também vítima de estupro, o agressor, fillho dos donos da casa que a vítima alugava, foi absolvido pela Corte Superior, sob o fundamento de que não houve violência por parte do acusado, nem sinais de resistência por parte da vítima, em razão da ausência de arranhões, mordidas, contusões e feridas no corpo do acusado, o que significa que "M.Z, apesar do seu tamanho e força física, não fez nada, durante mais de quatro horas, para tentar repelir a suposta agressão”. A Corte Superior não só deixou de considerar a análise dos certificados médicos e outras provas relevantes juntadas aos autos, como incorporou no processo elementos alheios aos dados processuais, como as declarações do acusado através de uma carta, em que afirmou ter sido agredido sexualmente pela suposta vítima. $^{127}$ Os dois casos revelam expressamente como o preconceito e os estereótipos de gênero dos responsáveis pelo sistema de justiça interferem no processamento dos atos de violência baseados em gênero, que permanecem impunes e legitimados em sociedade.

Adotar programas que visem conscientizar os agentes estatais sobre os direitos das mulheres e sobre a reconfiguração dos papéis culturalmente criados para homens e mulheres é uma obrigação que os Estados devem assumir como forma de sensibilizar as autoridades para as questões relacionadas ao gênero e tornar efetivo o acesso à justiça por mulheres vítimas de violência. $\mathrm{O}$ fato das autoridades demonstrarem-se insensíveis à violência com base no gênero e às consequências destas violações para as mulheres vítimas pode ser demonstrado no caso Paulina Del Carmen Ramírez Jacinto vs. México ${ }^{128}$. Neste caso, solucionado através da solução amistosa, a vítima, menor de idade, grávida em decorrência de estupro

\footnotetext{
${ }^{125}$ CIDH, Solução Amistosa, caso 12.350, M.Z (Bolívia). Outubro 10, 2001.

${ }^{126}$ CLADEM, Sistematização de Experiências em Litígio Internacional. Outubro, 2009. p. 107.

${ }^{127}$ CLADEM, Sistematização de Experiências em Litígio Internacional. Outubro, 2009. p. 94.
} 
sofrido, teve o seu direito a interromper a gravidez denegado pelo Promotor Público, após ter submetido a vítima à diversas consultas médicas para avaliar a veracidade das suas alegações. No relatório de solução amistosa, a Comissão declarou "a importância da adoção, pelos membros dos Estados, de medidas penais, civis, ou administrativas como forma de garantir que incidentes como os do presente caso sejam devidamente sancionados e não desfrutem da impunidade. A Comissão Interamericana repetidamente estabeleceu que o acesso de jure e de facto a remédios judiciais adequados e efetivos é indispensável para a proteção de todos os direitos da mulher, como também para observância da obrigação de agir com devida diligência quando ocorreram violações de direitos humanos". 129

A Comissão Interamericana relata as próprias declarações das autoridades no processamento dos casos de violência nas entrevistas conduzidas Instituto Latino-Americano das Nações Unidas para Prevenção do Crime e para o Tratamento dos Ofendidos (United Nations Latin American Institute for the Prevention of Crime and the Treatment of Offenders- INALUD) que revelam que os juízes evitam julgar os casos de violência baseada em gênero em favor das mulheres por temerem serem considerados "feministas" ou parecerem "afeminados" ou "menos homens". Outras pesquisas também revelam que os juízes não dão a mesma importância aos crimes de violência contra mulher, principalmente os crimes de natureza sexual, a que dão aos crimes de homicídio, crimes relacionados às drogas, etc. ${ }^{130}$

Outro grave problema ressaltado pela $\mathrm{CIDH}$ é o fato de que muitos sistemas judiciários estão incentivando o uso da conciliação como meio para resolução de casos de violência contra mulher, especialmente, os casos

\footnotetext{
${ }^{128}$ CIDH, Relatório 21/07, P 161-02, Solução Amistosa, Paulina del Carmen Ramírez Jacinto, México, Março. 9, 2007

${ }^{129}$ CIDH, Relatório 21/07, P 161-02, Solução Amistosa, Paulina del Carmen Ramírez Jacinto, México, Março. 9, 2007. para. 26.

${ }^{130} \mathrm{CIDH}$, Relatoria Especial sobre os Direitos da Mulher. Relatório sobre Acesso à Justiça para Mulheres Vítimas de Violência nas Américas, OEA/Ser.L/V//II, 20 Janeiro, 2007. Capítulo II, para. 159.
} 
de violência doméstica. No entanto, a CIDH salienta que a conciliação é inadmissível nesses casos, uma vez que a conciliação é uma alternativa somente para os casos em que há uma paridade entre as partes envolvidas, o que não se configura nos casos de violência. Caso a conciliação fosse permitida nesses casos, estar-se-ia admitindo que os crimes se tornassem um objeto de negociação e transação entre a vítima e o agressor, que possuem uma relação fortemente caracterizada pela desigualdade. Como regra, os agressores não cumprem o acordo celebrado, submetendo a vítima a novos episódios de violência, que poderiam ser evitados, caso os atos praticados tivessem sido efetivamente processados pelas autoridades competentes desde o primeiro momento em foram relatados. ${ }^{131}$

Além dos obstáculos relacionados à discriminação de gênero presente na atuação das autoridades em face dos casos de violência baseada em gênero, as mulheres também têm que enfrentar as barreiras estruturais dos sistemas judiciários que afetam o processamento destes crimes. A $\mathrm{CIDH}$ identificou um conjunto de fatores que impedem o seu devido processamento. São eles: a inexistência de órgãos judiciais nas áreas rurais, pobres e marginalizadas; ausência de advogados dativos para mulheres vítimas que são indigentes; falta de recursos humanos e financeiros para solucionar os problemas estruturais; ausência de unidades especializadas dentro dos sistemas de justiça para tratar de casos dessa natureza. ${ }^{132}$ Por último, a CIDH ressalta a importância da existência de um sistema efetivo de informações que compile estatísticas de casos de violência contra mulher, visando analisar as possíveis causas e tendências destes crimes, além de avaliar a resposta do sistema judiciário a estas práticas. A ausência de informações e estatísticas impede esforços para criar intervenções

\footnotetext{
${ }^{131}$ Ver CIDH, Relatoria Especial sobre os Direitos da Mulher. Relatório sobre Violência e Discriminação contra a Mulher no Conflito Armado na Colômbia, OEA OEA/Ser.L/V/II, 18 de outubro, 2006. Capítulo V. para. 209; CIDH, Relatoria Especial sobre os Direitos da Mulher. Relatório sobre Acesso à Justiça para Mulheres Vítimas de Violência nas Américas, OEA/Ser.L/V//II, 20 Janeiro, 2007. Capítulo II, para. 161.

${ }^{132} \mathrm{CIDH}$, Relatoria Especial sobre os Direitos da Mulher. Relatório sobre Acesso à Justiça para Mulheres Vítimas de Violência nas Américas, OEA/Ser.L/V//II, 20 Janeiro, 2007. Capítulo II, para. 181-183.
} 
estratégicas e específicas para o combate à violência de gênero, além de minimizarem a magnitude do problema. As informações devem ser compartilhadas entre órgãos responsáveis de forma organizada e coordenada, buscando ainda classificar os crimes pelo tipo de violência sofrida, e pelas características da vítima, como raça, idade, origem étnica, visando criar respostas de acordo com as especificidades de cada caso. ${ }^{133}$

Reconhecendo as inúmeras diferenças existentes entre as mulheres que podem potencializar a sua situação de vulnerabilidade, a CIDH enfatiza a necessidade de justiças de paz, ouvidorias, serviços básicos de atendimentos às mulheres vítimas de violência e serviços legais pro bono, além fornecer informações sobre os procedimentos legais existentes que possam salvaguardá-las quando vítimas de atos de violência. ${ }^{134}$

\section{b.3) Deficiências na prevenção}

Enquanto o Estado é claramente responsável por atos ou omissões praticadas por seus agentes, em alguns casos, o Estado terá a obrigação de prevenir e responder atos de particulares. O princípio da devida diligência teve papel fundamental da delimitação da responsabilidade do Estado para prevenir e responder as violações de direitos humanos praticadas por agentes não-estatais. Conforme estabelecido pela Corte Interamericana no caso Velásquez Rodriguez Vs. Honduras, "o dever de prevenção abarca todas aquelas medidas de caráter jurídico, político, administrativo e cultural que promovam a salvaguarda dos direitos humanos e assegurem que as eventuais violações dos mesmos sejam efetivamente consideradas e tratadas como um fato ilícito, suscetível de sanção para quem as cometa, assim

\footnotetext{
${ }^{133}$ CIDH, Relatoria Especial sobre os Direitos da Mulher. Relatório sobre Acesso à Justiça para Mulheres Vítimas de Violência nas Américas, OEA/Ser.L/V//II, 20 Janeiro, 2007. Capítulo II, para. 189-193.

${ }^{134}$ CIDH, Relatoria Especial sobre os Direitos da Mulher. Relatório sobre Acesso à Justiça para Mulheres Vítimas de Violência nas Américas, OEA/Ser.L/V//II, 20 Janeiro, 2007. Capítulo II, para. 184-185.
} 
como a obrigação de indenizar a vítima por suas consequiências prejudiciais." 135

No caso Maria da Penha Vs. Brasil, a Comissão ressaltou expressamente a obrigação dos Estados na prevenção dos atos de violência ao declarar que o Estado não havia descumprido com a sua obrigação de exercer a devida diligência para prevenir, sancionar e erradicar a violência doméstica, ao não condenar e punir o agressor da vítima. A Comissão concluiu que a violação faz parte de um padrão generalizado de negligência e falta de efetividade do Estado, que não somente violou a obrigação de processar e condenar, como também a obrigação de prevenir essas práticas degradantes. $^{136}$

Os maiores problemas na prevenção e proteção das mulheres vítimas de violência estão relacionados à ausência de medidas protetivas de urgência. As autoridades estatais não costumam executar ou acompanhar efetivamente as ordens restritivas ou outras medidas preventivas que visam assegurar a proteção das mulheres contra ameaças de violência feitas pelo agressor. ${ }^{137}$ A inação do Estado é explicada pela falta de credibilidade nos relatos das vítimas, principalmente, nos casos de violência doméstica e nos casos de violência sexual. Mesmo nos casos em que as mulheres vítimas conseguem obter as medidas de urgência, as autoridades falham na garantia da devida execução dessas medidas ou no seu monitoramento, ocasionando a continuidade dos atos de violência, muitas vezes de forma mais agravada, como forma do agressor demonstrar a sua insatisfação pelas medidas preventivas impostas contra ele. ${ }^{138}$ Quando uma medida protetiva de urgência não é reforçada ou monitorada pelo Estado, as mulheres

\footnotetext{
${ }^{135}$ CORTE IDH, Caso Velásquez Rodríguez vs .Honduras. Sentença de 29 de julho de 1988. para.174-175.

${ }_{136}$ CIDH, Mérito, No 54/01, Maria da Penha Fernandes (Brasil). Abril 16, 2001. para. 56.

${ }^{137}$ CIDH, Relatoria Especial sobre os Direitos da Mulher. Relatório sobre Acesso à Justiça para Mulheres Vítimas de Violência nas Américas, OEA/Ser.L/V//II, 20 Janeiro, 2007. Capítulo II. para. 166.

${ }^{138} \mathrm{CIDH}$, Relatoria Especial sobre os Direitos da Mulher. Relatório sobre Acesso à Justiça para Mulheres Vítimas de Violência nas Américas, OEA/Ser.L/V//II, 20 Janeiro, 2007. Capítulo II. para. 166-167.
} 
continuam sendo vítimas de atos de violência, que podem resultar na sua morte e também em atos de violência contra os seus filhos ou outros membros da família. ${ }^{139}$

A atuação para prevenção da violência baseada em gênero compõe a obrigação positiva dos Estados de agir com devida diligência para evitar essas práticas, e deve ser exercida em face de atos de agente estatais, e também de particulares, quando os Estados estão cientes de que os atos de violência representam uma ameaça real e iminente. ${ }^{140}$ Entre as principais deficiências apontadas pela Relatoria estão a ausência de aplicação pela polícia e pelo poder judiciário de medidas civis e de sanções penais contra os atos de violência, bem como a inadequada provisão de serviços específicos, como abrigos para mulheres vítimas de violência, que não possuem condições de continuarem convivendo com seus agressores, nos casos de violência intra-familiar. ${ }^{141}$

Em relação aos serviços específicos que devem ser fornecidos para as mulheres vítimas de violência, o relatório sobre $O$ Direito das Mulheres no Haiti a uma Vida Livre de Violência e Discriminação ${ }^{142}$ destina um capítulo especial para os serviços de saúde que devem ser fornecidos às mulheres vítimas. Estes serviços devem ser fornecidos, de forma urgente e

\footnotetext{
139 A Relatoria Especial sobre os Direitos das Mulheres, em seu Comunicado de Imprensa $\mathrm{n}^{\mathbf{o}}$ 20/04, ao avaliar a efetividade dos direitos das mulheres na Guatemala a um vida livre de violência e discriminação, afirmou que a violência contra a mulher é uma importante questão de direitos humanos que não somente afeta as mulheres, mas também seus filhos e filhas, suas famílias, e a sociedade em geral.

140 A Relatoria Especial das Nações Unidas sobre Violência contra as Mulheres, suas Causas e Consequências, também estabelece que, como regra de prevenção, os Estados devem adotar uma legislação específica, desenvolver campanhas de conscientização contra a violência contra a mulher, estabelecer um treinamento dos agentes estatais para as questões de gênero e incentivar a participação de homens e meninos em projetos direcionados a eliminação da violência de gênero. A Relatoria menciona algumas medidas de assistência específicas às mulheres vítimas de violência tomadas pelos Estados no que se refere à obrigação de devida diligência, como, por exemplo, assistência de saúde, assistência legal, abrigos, auxílio financeiro, etc. Ver Relatório da Relatoria Especial das Nações Unidas sobre Violência contra as Mulheres, suas Causas e Consequências, $O$ Standard de Devida Diligência como Ferramenta para Eliminação da Violência contra as Mulheres, E/CN. 4/2006/61, para.

${ }^{141} \mathrm{CIDH}$, Relatoria Especial sobre os Direitos da Mulher. Relatório sobre Acesso à Justiça para Mulheres Vítimas de Violência nas Américas, OEA/Ser.L/V//II, 20 Janeiro, 2007. Capítulo II. para. 170-171.

142 CIDH, Relatoria Especial sobre os Direitos da Mulher. Relatório sobre o Direito das Mulheres no Haiti a um Vida Livre de Violência e Discriminação, OEA/Ser.L/V/II, 10 Março, 2009.
} 
especializada, visando prevenir que os atos de violência gerem danos ainda mais graves. A violência afeta mulheres, e também seus filhos, de várias maneiras, incluindo consequências na sua saúde física, emocional e psicológica a curto e longo prazo. Em alguns casos, priva as mulheres da oportunidade de trabalhar ou participar de atividades econômicas para sustentar a si e suas famílias. ${ }^{143}$ A CIDH identificou alguns dos efeitos dessa violência sobre as vítimas: o trauma que acompanha o ato, a rejeição e estigmatização por suas comunidades, famílias e parceiros; gravidez indesejada ${ }^{144}$; danos aos órgãos sexuais reprodutivos; HIV e outras infecções sexualmente transmissíveis ${ }^{145}$; dor crônica, deficiência física; abuso de droga; depressão; suicídio; entre outros.

Além disso, a Relatoria ressalta que as medidas de prevenção e proteção costumam ser a curto-prazo, sem considerarem a possibilidade de continuidade das agressões e a revitimização das mulheres. A ausência de percepção dos riscos que a falha do monitoramento das medidas de proteção pode gerar se justifica pela maior consideração dada ao maior impacto que a ordem restritiva vai ter sobre o agressor, e não sobre a proteção que as medidas devem proporcionar à vítima. A CIDH revela que nos casos de crimes de natureza sexual, as medidas protetivas têm como

\footnotetext{
${ }^{143}$ A Comissão Interamericana ressalta que estudos mostram que a maioria das mulheres no Haiti são chefes de famílias e moram sozinhas com seus fihos. Relatos de moradores indicam que os grupos armados têm se beneficiado dessa situação para praticar atos de violência, uma vez que as mulheres sozinhas, com seus filhos, são menos propensas para resistir à invasão.

${ }^{144}$ Uma série de relatos feito à Comissão dos casos de estupro do Haiti indicam que, uma vez que a família da vítima está consciente de mulher violentada sexualmente está grávida, ela é forçada a casar com o agressor (nos casos em que o agressor é um vizinho ou residente no comunidade), ou expulsos de sua casa (nos casos em que o agressor é um membro de uma gangue armada, ou em casos de violência intra-familiar onde o agressor é um parente da vítima).

${ }^{145} \mathrm{O}$ relatório sobre $O$ Direito das Mulheres no Haiti a uma Vida Livre de Violência e Discriminação ressalta que a violência sexual constitui um instrumento fundamental na disseminação da infecção VIH / SIDA e outras DST's entre as mulheres no Haiti. A transmissão do HIV através de atos de violência sexual é muito elevada, especialmente quando a maioria dos membros de gangues que realizam estupro em massa estão em uma categoria de alto risco e não utilizam regularmente a proteçcão contra doenças sexualmente transmissíveis. CIDH, Relatoria Especial sobre os Direitos da Mulher. Relatório sobre o Direito das Mulheres no Haiti a um Vida Livre de Violência e Discriminação, OEA/Ser.L/V/II, 10 Março, 2009. para. 152.
} 
critério o perigo que o agressor representa para a sociedade, e não a segurança e proteção da vítima. ${ }^{146}$

Em relação às medidas que devem ser tomadas pelos Estados estão: (i) adotar políticas destinadas a reconfigurar os estereótipos sobre o papel da mulher na sociedade e promover a erradicação de padrões sociais discriminatórios obstrutivos ao seu acesso pleno à justiça; (ii) reforçar as políticas destinadas a prevenir actos de violência contra as mulheres através de abordagem abrangente que inclui a justiça, educação e setores de saúde e que abrange as diversas manifestações da violência e os contextos em que ocorrem; (iii) criar campanhas e divulgar informações dirigidas ao público em geral para educá-lo sobre o dever de respeitar os direitos políticos, econômicos, sociais, culturais, sexuais e reprodutivos das mulheres, sobre os serviços jurídicos e recursos judiciais disponíveis para as mulheres cujos direitos foram violados e quanto às consequências jurídicas para os infractores; (iv) elaborar e institucionalizar programas de treinamento direcionados a todos os agentes estatais envolvidos no monitoramento e supervisão de medidas protetivas e medidas de prevenção de atos de violência contra a mulher - particularmente na atividade da polícia - que possam instruí-los sobre a necessidade de garantir a aplicação e observância dessas medidas e sanções para o não cumprimento dessas medidas; (vi) implementar recursos judiciais de natureza cautelar - simples, rápido e acessível - que possam evitar situações de violência contra a mulher; (vii) e fornecimento de serviços especializados para mulheres vítimas de violência e seus filhos. $^{147}$

\footnotetext{
${ }^{146} \mathrm{CIDH}$, Relatoria Especial sobre os Direitos da Mulher. Relatório sobre o Direito das Mulheres no Haiti a um Vida Livre de Violência e Discriminação, OEA/Ser.L/V/II, 10 Março, 2009. para.139-141.

${ }^{147} \mathrm{CIDH}$, Relatoria Especial sobre os Direitos da Mulher. Relatório sobre Acesso à Justiça para Mulheres Vítimas de Violência nas Américas, OEA/Ser.L/V//II, 20 Janeiro, 2007. Capítulo III. pp. 17.
} 


\section{c) Ineficácia na formulação, aplicação e interpretação das leis}

Segundo a Comissão Interamericana, as deficiências na aplicação e interpretação nas leis civis e criminais geram dois obstáculos ao acesso à justiça nos casos de violência baseada em gênero: o primeiro deles está relacionado às lacunas e deficiências nas próprias leis, que apresentam conceitos discriminatórios e desvantajosos para as mulheres; e o outro está relacionado às dificuldades das autoridades de garantir a correta aplicação e interpretação dos instrumentos legais já existentes. ${ }^{148}$

\section{c.1) Deficiências e lacunas das leis}

A Comissão Interamericana ressalta que a grande parte dos instrumentos legais não faz referência às diferentes formas de manifestação de violência cometidas contras as mulheres, como a violência física, psicológica e sexual, conforme o faz a Convenção de Belém do Pará. Muitos documentos não mencionam todos os espaços relacionais que a violência de gênero pode ocorrer, privilegiando os casos de violência ocorridos no ambiente intra-familiar, excluindo outros contextos em que a violência pode se manifestar, como o espaço urbano, social, ambiente de trabalho institucional, e deixando sem amparo as mulheres vítimas de violência nestes contextos. ${ }^{149}$ Outra lacuna presente nas leis é a ausência de previsão de reparações às mulheres vítimas de violência. As mulheres que têm os seus direitos violados pelos atos de violência praticados contra elas têm direito à devida compensação pelos danos sofridos.

Ainda como deficiência apontada pela CIDH está o fato das leis ainda estarem imbuídas de princípios conservadores que visam, em primeiro lugar, a preservação da família e valores como a honra, em detrimento do direito das mulheres de viverem livres da discriminação e da

\footnotetext{
${ }^{148} \mathrm{CIDH}$, Relatoria Especial sobre os Direitos da Mulher. Relatório sobre Acesso à Justiça para Mulheres Vítimas de Violência nas Américas, OEA/Ser.L/V//II, 20 Janeiro, 2007. Capítulo II, para. 217.
} 
violência baseada em gênero. Busca-se proteger mais a família do que o indivíduo, ignorando-se os membros da família individualmente, principalmente, as mulheres. ${ }^{150}$ Outras provisões discriminatórias e conservadoras presentes em legislação civil $^{151}$ e penal de alguns países são as seguintes: definições de estupro que requerem para caracterização do crime sinais do uso da força e da violência ao invés da ausência de consentimento $^{152}$; o tratamento do crime de estupro como um crime contra a honra e a decência, e não como uma violação da integridade física da mulher; término do procedimento criminal quando a vítima retira a acusação; e penalidades inadequadas previstas para os crimes de violência contra a mulher. ${ }^{153}$

\section{c.2) Ineficácia na aplicação e interpretação das leis}

Uma variedade de fatores pode influenciar a efetiva aplicação e interpretação das leis pelas autoridades competentes para processar e julgar os casos de violência baseada em gênero. A CIDH indica os principais deles: ausência de regulação para implementar a legislação; a falta de programas de treinamento para capacitar os agentes públicos a interpretarem e aplicarem as leis a partir de uma perspectiva de gênero; excessivo volume de trabalho atribuído às autoridades responsáveis; e o desconhecimento do público em geral em relação à legislação existente e

\footnotetext{
${ }^{149} \mathrm{CIDH}$, Relatoria Especial sobre os Direitos da Mulher. Relatório sobre Acesso à Justiça para Mulheres Vítimas de Violência nas Américas, OEA/Ser.L/V//II, 20 Janeiro, 2007. Capítulo II, para. 219.

${ }^{150} \mathrm{CIDH}$, Relatoria Especial sobre os Direitos da Mulher. Relatório sobre Acesso à Justiça para Mulheres Vítimas de Violência nas Américas, OEA/Ser.L/V//II, 20 Janeiro, 2007. Capítulo II, para. 220.

${ }^{151}$ Ver caso CIDH, Mérito, No 4/01, Maria Eugenia Morales de Sierra (Guatemala). Janeiro 19, 2001.

${ }^{152}$ Ver caso CIDH, Solução Amistosa, caso 12.041, M.M (Peru). Março 17, 2000.

${ }^{153}$ A Comissão Interamericana informou que, em alguns países como Nicarágua, Panamá, Uruguai e Venezuela, ainda existem leis que permitem que os agressores não sejam punidos pelos atos de violência sexual, caso concordem em casar com a vítima, em nome de valores como a honra, virgindade, castidade e moralidade que prevalecem sobre o direito das mulheres a uma vida livre de violência. Ver CIDH, Relatoria Especial sobre os Direitos da Mulher. Relatório sobre Acesso à Justiça para Mulheres Vítimas de Violência nas Américas, OEA/Ser.L/V//II, 20 Janeiro, 2007. Capítulo II, para. 221-222.
} 
sobre a forma como interpretá-la. ${ }^{154}$ Estudos realizados pela $\mathrm{CIDH}$ revelam que tanto as autoridades, como as mulheres vítimas, desconhecem a existência de mecanismos internacionais de proteção dos direitos humanos que podem ser aplicados e interpretados para reenforçar a garantia de seus direitos que foram violados ou relutam em aplicar os tratados internacionais de direitos humanos como parte do direito doméstico, especialmente aqueles relacionados à proteção dos direitos humanos das mulheres, como a Convenção de Belém do Pará e a CEDAW. ${ }^{155}$

O caráter patriarcal do sistema judiciário também faz com que os crimes de violência contra a mulher sejam julgados como inferiores e punidos com penas mais brandas pelas autoridades, principalmente, nos casos de violência sexual. Esse problema enaltece a importância da institucionalização de programas que busquem modificar os comportamentos discriminatórios praticados pelas autoridades, tornando-as mais sensíveis às violações baseadas em gênero. ${ }^{156} \mathrm{O}$ fato dos crimes de violência contra a mulher serem considerados como não prioritários impede também a destinação necessária de recursos humanos e financeiros para a efetiva aplicação e interpretação da legislação existente. A aplicação de reparações e de serviços assistenciais previstos em lei para mulheres vítimas de violência e seus filhos previstos representa custos adicionais para o Estado, que não destinam as verbas necessárias para o cumprimento destas exigências legais. A Comissão Interamericana enfatiza a importância de serviços especializados e mutidisciplinares para mulheres que se tornam vítimas de violência para auxiliá-las na superação dos danos físicos e psicológicos sofridos. No entanto, ainda que muitos países tenham previsto em sua legislação programas e serviços que tenham por objetivo o auxílio

\footnotetext{
${ }^{154} \mathrm{CIDH}$, Relatoria Especial sobre os Direitos da Mulher. Relatório sobre Acesso à Justiça para Mulheres Vítimas de Violência nas Américas, OEA/Ser.L/V//II, 20 Janeiro, 2007. Capítulo II, para. 224-228.

${ }^{155}$ CIDH, Relatoria Especial sobre os Direitos da Mulher. Relatório sobre Acesso à Justiça para Mulheres Vítimas de Violência nas Américas, OEA/Ser.L/V//II, 20 Janeiro, 2007. Capítulo II, para. 228-231.
} 
às mulheres vítimas, as dificuldades concentram-se- em grande parte, na implementação dessas medidas. As maiores dificuldades apontadas pela Comissão Interamericana são: falhas de coordenação e colaboração entre programas de auxílio; deficiências na prestação de serviços que as vítimas e seus filhos necessitam; ausência de recursos suficientes para garantir a permanência da prestação desses serviços; a cobertura geográfica desses serviços é limitada; além das dificuldades enfrentadas pelas mulheres pobres, marginalizadas e residentes em áreas rurais. ${ }^{157}$

${ }^{156} \mathrm{CIDH}$, Relatoria Especial sobre os Direitos da Mulher. Relatório sobre Acesso à Justiça para Mulheres Vítimas de Violência nas Américas, OEA/Ser.L/V//II, 20 Janeiro, 2007. Capítulo II, para. 225.

${ }^{157} \mathrm{CIDH}$, Relatoria Especial sobre os Direitos da Mulher. Relatório sobre Acesso à Justiça para Mulheres Vítimas de Violência nas Américas, OEA/Ser.L/V//II, 20 Janeiro, 2007. Capítulo II, para. 234-236. 


\section{Capítulo 3. O caso González e outras vs. México ("Caso Campo Algodonero") e a análise da jurisprudência da Corte Interamericana de Direitos Humanos}

Em relação ao tema da discriminação e violência baseadas em gênero, são recentes os casos em que a Corte Interamericana reconheceu a violação dos direitos das mulheres vítimas sob uma perspectiva de gênero. Em 2006, no caso Penal Miguel Castro Castro vs. Peru ${ }^{158}$, pela primeira vez, a Corte aplicou a Convenção de Belém do Pará como marco jurídico para interpretação e análise dos casos de suposta responsabilização do Estado pela violência de gênero perpetrada contra as mulheres. ${ }^{159}$ Embora a violência contra as mulheres apareça como uma questão secundária, sendo só uma das alegações de violação contra o Estado, dentre outras violações de direitos que não possuem como base as questões de gênero, o caso tem sua grande importância atribuída ao fato de ter sido responsável pela formação de um precedente sobre a matéria na Corte Interamericana. No caso Campo Algodonero vs. México ${ }^{160}$, que trata especificamente sobre a violação de direitos das mulheres com base no gênero, julgado em 2009, a Corte aplica a Convenção Belém do Pará como marco normativo fundamental para entender cada uma das violações dos direitos das mulheres presentes no caso. Os dois casos mais recentes julgados pela

\footnotetext{
${ }^{158}$ CORTE IDH, Caso Penal Miguel Castro Castro vs. Peru. Sentença de 25 de novembro de 2006.

159 Em 09 de setembro de 2004, a Comissão Interamericana de Direitos Humanos submeteu perante a Corte Interamericana de Direitos Humanos uma demanda contra o Estado do Peru alegando que os Estado é responsável pela violação dos direitos das "175 pessoas que resultaram feridas" e dos " 322 reclusos, que resultaram ilesos, mas foram submetidos a um tratamento cruel, desumano e degradante e de seus familiares durante a realização da "Operação Mudanza 1" pelo Estado dentro do Presídio Miguel Castro Castro. A operação ocorreu em um período em que Estado do Peru viveu um intenso conflito entre grupos armados, como o Sendero Luminoso e o Movimento Revolucionário Tupac Amarú, e forças policiais e militares. A operação denominada "Mudanza 1", que oficialmente consistia na transferência das 135 mulheres, que se encontravam presas no presídio Miguel Castro Castro, para uma outra unidade prisional, se tratava de um atentado premeditado, cujo objetivo era atentar contra a vida dos presos políticos que se encontravam em dois dos seis pavilhões da penitenciária.

${ }^{160}$ CORTE IDH, Caso González y Otras ("Campo Algodonero") vs. México. Sentença de 16 de novembro de 2009.
} 
Corte IDH acerca da temática da violência de gênero e acesso à justiça para mulheres vítimas de violência são os casos caso Fernández Ortega y Otros vs. México ${ }^{161}$ e caso Rosendo Cantú y Outra vs. México ${ }^{162}$, que abordam a violência sexual sofrida por mulheres indígenas e praticada por militares que ocupam suas comunidades.

O presente capítulo se dividirá em duas partes: primeiramente, buscarse-á desenvolver o estudo aprofundado do caso Campo Algodonero vs. México, que apresenta grande relevância para o objetivo do trabalho, por tratar especificamente sobre a relação entre discriminação de gênero, violência contra a mulher e deficiências para o acesso efetivo aos mecanismos judiciais. Posteriormente, far-se-á um panorama geral da jurisprudência da Corte IDH acerca dos temas relacionados à discriminação e violência baseada em gênero, ressaltando os principais aspectos dos casos analisados e a evolução do Sistema Interamericano no reconhecimento da violência baseada em gênero e nas suas implicações para as mulheres vítimas de violência.

\subsection{O caso González e outras vs. México (“Campo Algodonero”)}

Em sentença proferida em 06 de novembro de 2009, a Corte Interamericana responsabilizou o Estado por uma série de violações de direitos humanos pela prática de irregularidades e inconsistências na prevenção e na investigação do desaparecimento e morte de três jovens mulheres na Ciudad Juárez, México, apresenta grande relevância para o objetivo do trabalho, que pretende analisar os obstáculos enfrentados por mulheres vítimas de violência para que obtenham o acesso efetivo à justiça e para que as violações sofridas sejam prevenidas, investigadas, punidas e reparadas pelos Estados.

\footnotetext{
${ }^{161}$ CORTE IDH, Caso Fernández Ortega y Otros vs. México. Sentença de 30 de agosto de 2010.

${ }^{162}$ CORTE IDH, Caso Rosendo Cantu y Otra vs. México. Sentença de 31 de agosto de 2010.
} 


\subsubsection{Apresentação do caso: fatos e demanda}

Em 04 de novembro de 2007, a Comissão Interamericana de Direitos Humanos apresentou uma demanda contra o estado do México alegando a responsabilidade internacional do Estado pelo desaparecimento e posterior morte das jovens Claudia Ivette González, Esmeralda Herrera Monreal e Laura Berenice Ramos Monárrez (casos no 12.496, 12.497 e 12.498), cujos corpos foram encontrados em uma campo de plantação de algodão da Ciudad Juárez, em 06 de novembro de 2001, com sinais que denotam a prática de violência sexual. ${ }^{163}$

(1) Laura Berenice Ramos Monárrez tinha 17 anos e era estudante do quinto semestre do ensino médio. A última notícia que se teve foi um telefonema dado a sua amiga para avisá-la que estava pronta para ir a uma festa, no sábado, dia 22 de setembro de 2001. A denúncia apresentada, afirmou que desapareceu na terça-feira, dia 25 de setembro de $2001 ;{ }^{164}$

(2) Claudia Ivette González tinha 20 anos e trabalhava numa empresa de cosméticos. Em 10 de outubro de 2001, chegou dois minutos atrasada na empresa, na qual foi impedida de entrar. Naquele mesmo dia ela desapareceu; 165

(3) Esmeralda Herrera Monreal tinha 15 anos e tinha um "grau de instrução para a escola secundária”. Ela desapareceu na segunda-feira, dia 29 de outubro de 2001, após deixar a casa onde ela trabalhava como empregada doméstica. ${ }^{166}$

O estado do México foi acusado sob as alegações de falta de medidas de proteção das vítimas, considerando que duas delas eram menores de idade; falta de prevenção destes crimes diante do conhecimento da

\footnotetext{
${ }^{163}$ CORTE IDH, Caso González y Otras ("Campo Algodonero") vs. México. Sentença de 16 de novembro de 2009. para. 2-6

${ }^{164}$ CORTE IDH, Caso González y Otras ("Campo Algodonero") vs. México. Sentença de 16 de novembro de 2009. para. 165.

${ }^{165}$ CORTE IDH, Caso González y Otras ("Campo Algodonero") vs. México. Sentença de 16 de novembro de 2009. para. 166.
} 
existência de um padrão estrutural de violência de gênero na cidade; falta de resposta das autoridades diante do desaparecimento das jovens; falta de devida diligência na investigação dos assassinatos, assim como a denegação de justiça e a falta de reparação adequada. A Comissão solicitou que a Corte declare o Estado responsável pela violação dos direitos consagrados nos artigos $4^{\circ}$ (direito à vida), $5^{\circ}$ (direito à integridade pessoal), $8^{\circ}$ (garantias judiciais), 19 (direitos da criança) e 25 (proteção judicial) da Convenção Americana, em relação às obrigações estabelecidas nos artigos 1.1 (obrigação de respeitar e garantir os direitos) e $2^{\circ}$ (dever de adotar disposições de direito interno) do mesmo documento, e em cumprimento às obrigações que derivam do artigo $7^{\circ}$ da Convenção Belém do Pará. ${ }^{167}$ Adicionalmente aos artigos solicitados pela Comissão, a Associação Nacional de Procuradores Democráticos A.C, a Comissão da América Latina e Caribe para a defesa dos Direitos da Mulher (CLADEM), a Rede dos Cidadãos para Não-Violência e Dignidade Humana e o Centro para o Desenvolvimento Integral da Mulher A. C., representantes das vítimas, solicitaram que a Corte declarasse que o Estado é responsável pela violação dos direitos consagrados nos artigos $7^{\circ}$ (direito à liberdade pessoal) e 11 (direito à dignidade e à honra) da Convenção, todos eles relacionados com as obrigações gerais que derivam dos artigos 1.1 e $2^{\circ}$ da mesma, assim como o artigo $7^{\circ}$ da Convenção Belém do Pará, em conexão com os artigos $8^{\circ}$ e $9^{\circ}$ do mesmo instrumento. Ainda solicitaram a violação do direito consagrado no artigo $5^{\circ}$ da Convenção Americana em prejuízo das vítimas. Além da inclusão dos mencionados artigos, os representantes solicitaram o aumento do número de vítimas para onze mulheres, em razão do alto índice de assassinatos ocorridos na Cidade de Juárez. ${ }^{168}$

\footnotetext{
166 CORTE IDH, Caso González y Otras (“Campo Algodonero”) vs. México. Sentença de 16 de novembro de 2009. para. 167.

167 CORTE IDH, Caso González y Otras ("Campo Algodonero") vs. México. Sentença de 16 de novembro de 2009. para. 3

${ }^{168}$ CORTE IDH, Caso González y Otras ("Campo Algodonero") vs. México. Sentença de 16 de novembro de 2009. para. 4.
} 
O estado do México reconheceu parcialmente a sua responsabilidade pelo descumprimento das obrigações contidas nos artigos 8.1 e 25.1 da Convenção Americana, em relação à denominada primeira etapa das investigações ${ }^{169}$ (entre 2001 e 2003), e do artigo $5^{\circ}$ da mesma em relação aos familiares das vítimas Claudia Ivette González, Esmeralda Herrera Monreal e Laura Berenice Ramos Monárrez. Também solicitou que a Corte declare a inexistência de violações por parte do estado mexicano aos artigos 4.1, 5.1, 7, 11 e 19 da Convenção Americana em relação às vítimas; e que declare que o Estado cumpriu com as suas obrigações de prevenção, investigação e reparação, contidas nos artigos 4.1 e 5.1, em relação ao artigo 1.1 da Convenção Americana. ${ }^{170}$

Em relação à solicitação do Estado, a Corte declarou que cessaram as controvérsias sobre a violação dos artigos 5.1, 8.1, 25.1 da Convenção Americana, em prejuízo dos familiares das vítimas identificados e sobre as violações aceitas pelo Estado na denominada "primeira etapa das investigações". De outra parte, a Corte declara que subsiste a controvérsia em torno das alegadas violações dos artigos $4^{\circ}, 5^{\circ}, 7^{\circ}, 11$ e 19 da Convenção Americana, em relação aos artigos 1.1 e $2^{\circ}$ do mesmo documento e do artigo $7^{\circ}$ da Convenção de Belém do Pará. Subsiste também a controvérsia em relação aos artigos 5.1 da Convenção Americana, em relação aos familiares das vítimas, pelos fatos alegados não reconhecidos pelo Estado, assim como em relação aos artigos 8.1 e 25.1 da Convenção, em relação aos artigos 1.1 e $2^{\circ}$ da mesma, referente à "segunda etapa das investigações". ${ }^{171}$

\footnotetext{
${ }^{169}$ Segundo o Estado a segunda etapa das investigações ocorreu a partir do ano de 2004, em que o Estado alega que todas as regularidades já haviam sido sanadas, não subsistindo a responsabilidade estatal.

${ }^{170}$ CORTE IDH, Caso González y Otras ("Campo Algodonero") vs. México. Sentença de 16 de novembro de 2009. para. 22-25.

${ }^{171}$ CORTE IDH, Caso González y Otras ("Campo Algodonero") vs. México. Sentença de 16 de novembro de 2009. para. 29.
} 


\subsubsection{Contexto do caso - A violência estrutural e a discriminação de gênero na Ciudad Juárez}

A Ciudad Juárez é uma cidade do Estado do México, localizada ao norte do estado de Chihuahua, exatamente na fronteira com El Paso, Texas. Por ser uma região fronteiriça é porta de emigração, legal e ilegal, para os Estados Unidos e vem se caracterizando como maior pólo de delitos do estado, onde imperam o crime organizado, o narcotráfico, atividade de grupos ilícitos e um grande número de assassinatos e outros episódios de violência. É também um centro industrial importante, em que empresas nacionais e internacionais atraem um número cada vez maior de mão-deobra nacional e estrangeira em busca de oportunidades de emprego. A proximidade com a fronteira internacional, o crescimento desenfreado da população e a ausência de infra-estrutura e de serviços públicos suficientes contribuem para a formação de diferenças culturais, econômicas e sociais que geram graves problemas, como o crescimento do setor marginalizado e o aumento da inseguridade, da violência e da impunidade na região. ${ }^{172}$

A partir de 1993, iniciou-se um fenômeno caracterizado por um aumento significativo de homicídios e desaparecimentos de mulheres e meninas, além de diversas outras formas de discriminação baseadas em gênero. A maioria das mulheres assassinadas possuía entre 15 a 25 anos de idade, era estudante ou trabalhava nas indústrias locais, migrante e de origem humilde. Embora os crimes sejam, em sua grande maioria, independentes uns dos outros, diversos informes estabelecem fatores comuns entre os episódios, como o seqüestro seguido de cárcere privado e corpos encontrados em terrenos baldios com sinais de violência sexual, tortura e mutilações. ${ }^{173}$

\footnotetext{
${ }^{172}$ CORTE IDH, Caso González y Otras ("Campo Algodonero”) vs. México. Sentença de 16 de novembro de 2009. para. 113-115.

${ }^{173}$ CORTE IDH, Caso González y Otras ("Campo Algodonero”) vs. México. Sentença de 16 de novembro de 2009. para. 115-117.
} 
A questão de gênero é, portanto, um fator fundamental nos casos de violência na Ciudad Juárez, que consiste, segundo os representantes das vítimas, em uma situação caracterizada por uma violação reiterada e sistemática dos direitos humanos das mulheres. As mulheres e meninas são violentadas com crueldade pelo fato de serem mulheres e em razão de uma concepção errônea de sua inferioridade. O Estado assinalou que os homicídios possuem causas diversas, mas todas estão influenciadas por uma cultura de discriminação contra a mulher. Entre os fatores apresentados pelo estado mexicano como causa do alarmante aumento dos casos de violência contras mulheres na cidade está a mudança gerada nos papéis familiares tradicionalmente desempenhados por homens e mulheres na região. As muitas indústrias instaladas na cidade têm preferência pela contratação de mulheres, que têm demonstrado uma postura mais competitiva e independente economicamente, provocando uma transformação na vida familiar e nos estereótipos de gênero arraigados na sociedade de Juárez. ${ }^{\mathrm{i}} \mathrm{A}$ Relatora sobre Violência contra Mulher da ONU, em seu Relatório sobre Violência da Mulher em 2002, explicou que as forças de mudança que desafiam os próprios fundamentos do machismo, embora permitam que em longo prazo as mulheres possam superar a discriminação estrutural, podem também exacerbar a violência de gênero e o sofrimento das mulheres em curto prazo. A incapacidade machista dos homens para desempenhar papel distinto da função tradicional de provedor da família conduz ao abandono familiar, à instabilidade das relações, ao alcoolismo e à violência contra as mulheres. Mesmo os casos de assassinatos podem ser interpretados como uma tentativa desesperada de ater-se a normas discriminatórias que vem sendo superadas pela mudança nas condições socioeconômicas e pelo avanço dos direitos humanos. ${ }^{174}$

Outro fato caracterizador dos homicídios e desaparecimentos na Ciudad Juaréz é ausência de esclarecimento e investigação dos crimes,

\footnotetext{
${ }^{174}$ CORTE IDH, Caso González y Otras ("Campo Algodonero”) vs. México. Sentença de 16 de novembro de 2009. Para. 120.
} 
gerando uma atmosfera de impunidade em relação a essas práticas na região. O Relatório sobre a Situação de Violência Contra a Mulher na Cidade de Juaréz, México: o direito a não ser objeto de violência e discriminação ${ }^{175}$ observou que, embora tenha sido criada uma Procuradoria Especializada para investigar esses casos, as autoridades tinham uma tendência a responder as solicitações dos familiares das vítimas de forma discriminatória e desrespeitosa, sem a aplicação da devida diligência para investigar e julgar esses crimes e punir seus autores, bem como sem a aplicação da devida diligência para prevenir futuros assassinatos e desaparecimentos de mulheres e meninas da região. ${ }^{176}$

Conforme prova juntada aos autos do presente caso, as irregularidades nas investigações e nos processos incluem a demora no início das investigações, a lentidão das mesmas ou a inatividade nos arquivos, negligência e irregularidades na colheita e realização de provas e na identificação de corpos, perda de dados, extravio de partes de corpos, sob a custódia do Ministério Público, bem como a falta de contemplação dos ataques contra as mulheres como parte de um fenômeno global da violência de gênero. ${ }^{177}$ A Comissão e os representantes alegaram que as atitudes das autoridades do Estado contra os assassinatos de mulheres em Juarez foram notoriamente discriminatórias e lentas, uma situação que a Comissão descreveu como um "padrão preocupante de resposta e de concepções estereotipadas das mulheres desaparecidas". Em particular, o padrão "se manifestava na percepção dos funcionários do Estado de que a busca e proteção das mulheres desaparecidas não era importante”. As provas demonstraram que os funcionários do Estado de Chihuahua e da Ciudad Juárez minimizaram o problema e chegaram a culpar as vítimas por

\footnotetext{
${ }^{175} \mathrm{CIDH}$, Relatoria Especial sobre os Direitos da Mulher. Relatório sobre a Situação dos Direitos da Mulher na Cidade de Juárez, México: o Direito a não ser objeto de Violência e Discriminação, OEA/Ser.L/V/II.117, 7 Março, 2003

${ }^{176}$ CORTE IDH, Caso González y Otras ("Campo Algodonero") vs. México. Sentença de 16 de novembro de 2009. Para. 120.

${ }^{177}$ CORTE IDH, Caso González y Otras ("Campo Algodonero") vs. México. Sentença de 16 de novembro de 2009. para. 150 .
} 
seu destino, seja por sua forma de vestir, ou local onde trabalhavam, pela sua conduta, por andarem sozinhas ou por falta de cuidado dos pais. ${ }^{178}$

\subsubsection{Considerações da Corte Interamericana de Direitos Humanos acerca do caso}

Em sentença proferida em 06 de novembro de 2009, a Corte IDH, primeiramente, considerou pertinente estabelecer que os atos de violência que sofreram as três vítimas constituem violência contra a mulher, segundo a Convenção Americana e a Convenção de Belém do Pará. A Corte entendeu que os homicídios não só podem ser caracterizados como violência contra mulher, mas como violência contra a mulher em razão de gênero, sendo possível a classificação desses episódios como um feminicídio, que seria uma forma extrema de violência contra mulheres e meninas pelo simples fato de estarem em uma sociedade que as subordina, como alegado pela Comissão Interamericana e pelos representantes das vítimas. Eles argumentaram que "para determinar se o assassinato de uma mulher é um feminicídio, é necessário saber quem o comete, como ele o fez e em que contexto". Eles indicaram que, embora nem sempre tenham todas as informações disponíveis sobre os crimes deste tipo, há indicadores tais como a mutilação de partes do corpo, falta de seios e de genitálias, que indicam que esses assassinatos ocorreram em um grave contexto estrutural de violência baseada em gênero. ${ }^{179}$

No que se refere ao direito de garantia dos direitos previstos nos artigos $4^{\circ}, 5^{\circ}$ e $7^{\circ}$, em conformidade com o artigo 1.1 da Convenção Americana, e o artigo $7^{\circ}$ da Convenção de Belém do Pará, a Corte IDH analisou se o Estado cumpriu com o dever de prevenir efetivamente o desaparecimento e a morte sofrida pelas três vítimas, bem como de

\footnotetext{
${ }^{178}$ CORTE IDH, Caso González y Otras (“Campo Algodonero") vs. México. Sentença de 16 de novembro de 2009. para. 151-153.

${ }^{179}$ CORTE IDH, Caso González y Otras ("Campo Algodonero") vs. México. Sentença de 16 de novembro de 2009. para. 151-153.
} 
investigar e punir esses crimes com devida diligência. ${ }^{180}$ A Corte IDH também analisou se o Estado permitiu o acesso à justiça dos familiares das três vítimas, conforme estabelecido nos artigos $8^{\circ}$ e 25 , relacionados com os artigos 1.1 e $2^{\circ}$ da Convenção Americana.

A Corte IDH faz referência a alguns documentos internacionais do sistema ONU de proteção dos direitos humanos, ao se remeter à Recomendação Geral no 19 do Comitê CEDAW para salientar que "os Estados-Partes também podem ser responsabilizados por atos privados se não adotarem medidas com a devida diligência para impedir a violação de direitos ou para investigar e castigar os atos de violência e indenizar as vítimas", e à Declaração sobre a Eliminação da Violência contra a Mulher da Assembléia Geral das Nações Unidas que insta os Estados a procederem com a devida diligência a fim de prevenir, investigar e, conforme a legislação nacional, punir todo ato de violência contra a mulher, se tratando de atos perpetrados pelo Estado ou particulares. ${ }^{181}$

A Corte IDH destaca, dentre outras, as orientações fornecidas pela Relatora Especial sobre Violência contra as Mulheres da ONU acerca das medidas que devem ser adotadas pelo Estado para cumprir com as suas obrigações positivas estabelecidas nos instrumentos internacionais de proteção. São essas medidas: (i) a ratificação de instrumentos internacionais de direito humanos; (ii) garantia constitucional da igualdade da mulher; (iii) existência de leis nacionais e sanções administrativas que proporcionem reparação adequada às mulheres vítimas de violência; (iv) políticas ou planos de ação que abordem a questão da violência contra as mulheres; (v) sensibilização da justiça criminal e da polícia em relação às questões de gênero; (vi) acessibilidade e serviços de apoio às vítimas; (vii) existência de medidas para eliminação dos padrões discriminatórios no âmbito da

\footnotetext{
${ }^{180}$ CORTE IDH, Caso González y Otras ("Campo Algodonero”) vs. México. Sentença de 16 de novembro de 2009. para. 246.

${ }^{181}$ CORTE IDH, Caso González y Otras ("Campo Algodonero") vs. México. Sentença de 16 de novembro de 2009. para. 246
} 
educação e nos meios de comunicação; (viii) reunião de dados e estatísticas sobre a violência contra as mulheres. ${ }^{182}$

A Corte estabelece que existem dois momentos importantes para análise do dever de prevenção do Estado: o primeiro momento, anterior ao desaparecimento das vítimas, e o segundo momento, antes da localização dos corpos das vítimas. ${ }^{183}$ Em relação ao primeiro momento, a Corte IDH entende que o Estado não pode ser responsabilizado pela sua prevenção, por considerar que, embora houvesse o conhecimento de um padrão de violência na região, não havia um conhecimento de um perigo real e imediato em relação ao desaparecimento das jovens no referido caso. ${ }^{184}$ No entanto, no que se refere ao segundo momento, diante dos fatos e das orientações fornecidas, a Corte IDH entendeu que o Estado não demonstrou ter adotado as medidas necessárias para encontrar as vítimas com vida; não atuou com prontidão dentro das primeiras horas e dias após a denúncia, deixando de perder horas valiosas; se limitou a realizar formalidades e a tomar declarações que não repercutiram em ações de busca específicas; as atitudes dos agentes estatais e declarações dos funcionários aos familiares que davam a entender que as denúncias de desaparecimento não deviam ser tratadas com urgência. ${ }^{185}$. Segundo a Corte IDH, o descumprimento do dever de garantia é particularmente grave em razão do contexto de violência estrutural de gênero em Juárez conhecido pelo Estado. Essa situação de risco em que as mulheres estão inseridas impõe obrigações reforçadas ao Estado, conforme estabelecido no artigo 7.b da Convenção de Belém do Pará. Além disso, a Corte considera que o Estado não demonstrou ter adotado normas internas ou implementado as medidas necessárias para combater a violência e discriminação de gênero, conforme o artigo $2^{\circ}$ da

\footnotetext{
${ }^{182}$ CORTE IDH, Caso González y Otras (“Campo Algodonero”) vs. México. Sentença de 16 de novembro de 2009. para. 246

${ }^{183}$ CORTE IDH, Caso González y Otras ("Campo Algodonero") vs. México. Sentença de 16 de novembro de 2009. para. 281-282.

${ }^{184}$ CORTE IDH, Caso González y Otras ("Campo Algodonero") vs. México. Sentença de 16 de novembro de 2009. para. 281.

${ }^{185}$ CORTE IDH, Caso González y Otras ("Campo Algodonero") vs. México. Sentença de 16 de novembro de 2009. para. 281-282.
} 
Convenção Americana e o artigo 7.c da Convenção Belém do Pará, bem como não ficou demonstrado que o Estado promoveu a preparação adequada dos agentes e funcionários estatais para que pudessem compreender a complexidade do fenômeno de violência de gênero e desenvolvessem a habilidade e sensibilidade para tratar dos crimes dessa natureza. $^{186}$

Nesse sentido, a Corte IDH considera que o Estado violou os direitos à vida, à integridade pessoal e à liberdade pessoal consagrados nos artigos 4.1, 5.1 e 7.1 da Convenção Americana, em relação à obrigação geral de garantia contemplada no artigo 1.1 e à obrigação de adotar disposições de direitos interno contemplada no artigo $2^{\circ}$ do mesmo documento, assim como as obrigações contempladas no artigo 7.b e 7.c da Convenção Belém do Pará, em prejuízo das três vítimas. ${ }^{187}$

Da obrigação geral de garantia dos direitos à vida, à integridade pessoal e à liberdade pessoal deriva a obrigação de investigar os casos de violação desses direitos. O dever de investigar é uma obrigação de meio e não de resultado, que deve ser assumida pelo Estado como um dever jurídico próprio e não como uma simples formalidade condenada a não ser cumprida. A obrigação de investigar deve ser cumprida de forma diligente pelo Estado para evitar a impunidade, para impedir que esses crimes se repitam, e para não permitir que seja transmitido o espírito de aceitabilidade dessas práticas. A Corte Interamericana adotou a teoria da "obrigação processual", desenvolvida pela Corte Européia de Direitos Humanos, que consiste na obrigação de efetuar uma investigação oficial efetiva em casos de violação daquele direito. ${ }^{188}$ Segundo os padrões estabelecidos pela Corte IDH, o dever de investigar efetivamente uma violação de um direito consagrado dos documentos internacionais possui um alcance adicional

\footnotetext{
${ }^{186}$ CORTE IDH, Caso González y Otras (“Campo Algodonero”) vs. México. Sentença de 16 de novembro de 2009. para. 248.

${ }^{187}$ CORTE IDH, Caso González y Otras ("Campo Algodonero”) vs. México. Sentença de 16 de novembro de 2009. para. 254.

${ }^{188}$ CORTE IDH, Caso González y Otras ("Campo Algodonero") vs. México. Sentença de 16 de novembro de 2009. para. 285.
} 
quando se trata de vítima mulher em um marco de contexto de violência baseada em gênero. A Corte Européia já declarou que quando uma violação de direito foi motivada por razões de raça, é importante que as investigações sejam realizadas com vigor e imparcialidade, levando em conta a necessidade de reiterar a condenação do racismo por parte da sociedade e para manter a confiança das minorias na habilidade das autoridades. ${ }^{189}$ Esse critério é totalmente aplicável na análise do alcance do dever de devida diligência na investigação de casos de violência de gênero. ${ }^{190}$

Após a análise das alegadas irregularidades cometidas pelo Estado durante as investigações, quais sejam, as irregularidades na custódia das cenas do crime, no manejo das evidências, na elaboração de autópsias e na identificação e na entrega dos restos das vítimas; na demora injustificada e na inexistência de avanços significativos nas investigações; fragmentação das investigações; na falta de sanção dos funcionários públicos envolvidos com as irregularidades das investigações; e na negação de acesso ao expediente e demora ou negação de cópias do mesmo, a Corte concluiu que o Estado descumpriu com o seu dever de investigar e com o seu dever de garantir os direitos consagrados nos artigos 4.1, 5.1, 5.2 e 7.1 da Convenção Americana, em relação aos artigos 1.1 e $2^{\circ}$ da mesma e com o artigo 7.b e 7.c da Convenção Belém do Pará, em prejuízo das três vítimas. Pelas mesmas razões, o Estado violou os direitos de acesso à justiça e proteção judicial, consagrados nos artigos 8.1 e 25.1 da Convenção Americana, em relação com os artigos 1.1 e $2^{\circ}$ do mesmo documento e 7.b e 7.c da Convenção de Belém do Pará, em prejuízo dos familiares das três vítimas. ${ }^{191}$

A Corte IDH também ressaltou a observação feita pela CIDH que assinalou o vínculo entre a violência contra as mulheres e a discriminação

\footnotetext{
${ }^{189}$ CORTE EDH, Caso Angelova e Iliev v. Bulgaria, Sentença de 26 Julho de 2007. para.98. ${ }^{190}$ CORTE IDH, Caso González y Otras ("Campo Algodonero") vs. México. Sentença de 16 de novembro de 2009. para. 293.
} 
de gênero para apreciar o alcance de devida diligência no presente caso. As atitudes discriminatórias dos funcionários estatais tiveram um papel determinante no fracasso das investigações dos crimes. As mulheres e meninas assassinadas sofreram uma dupla discriminação, com base no gênero e na classe social, em razão da origem humilde das três vítimas, que as inseriu em uma situação de maior vulnerabilidade e se demonstrou como fator responsável pela omissão do Estado. ${ }^{192}$ A Corte IDH se utilizou de um precedente da Corte Européia de Direitos Humanos, o caso Opuz vs. Turquia $^{193}$, julgado em 2009, para sustentar que a inação do Estado para prevenir e sancionar atos de violência, mesmo que sem a intenção de discriminar as mulheres, se afetá-las desproporcionalmente, constituirá a responsabilidade do Estado pela violência de gênero, que é uma forma de discriminação contra as mulheres.

A Corte IDH observa que a conduta das autoridades durante a investigação dos crimes denota a existência de um padrão de discriminação contra a mulher na Ciudad de Juárez, percebido de forma implícita ou explícita na fala e na conduta das autoridades, contribuindo para perpetuação dos crimes de violência e para a impunidade dessas práticas. A criação e uso de estereótipos de gênero se converte, portanto, em uma das causas e consequências da violência baseada em gênero. ${ }^{194}$ Ante ao exposto, a Corte considera que o Estado violou o dever de não discriminação contido nos artigos 1.1 da Convenção, em relação com o dever de garantia dos direitos consagrados nos artigos 4.1, 5.1, 5.2 e 7.1 da Convenção Americana, em prejuízo das três vítimas, assim como em relação ao direito

\footnotetext{
${ }^{191}$ CORTE IDH, Caso González y Otras ("Campo Algodonero") vs. México. Sentença de 16 de novembro de 2009. para. 287.

192 CORTE IDH, Caso González y Otras ("Campo Algodonero") vs. México. Sentença de 16 de novembro de 2009. para. 292.

${ }^{193}$ CORTE EDH, Caso Opuz v. Turkey, Sentença de 09 de junho de 2009. para. 180, 191 e 200.

${ }^{194}$ CORTE IDH, Caso González y Otras ("Campo Algodonero") vs. México. Sentença de 16 de novembro de 2009. para. 295.
} 
ao acesso à justiça consagrado nos artigos 8.1 e 25.1 da Convenção, em prejuízo dos familiares das vítimas. ${ }^{195}$

Além das questões de gênero e classe social, a Corte IDH reconheceu a situação de maior risco das meninas, Laura Berenice Ramos e Esmeralda Herrera Monreal, em razão da sua idade. A Corte IDH já estabeleceu que as crianças merecem um tratamento especial em razão da sua menor idade e conseqüente vulnerabilidade, que corresponde a deveres específicos por parte da família, da sociedade e do Estado para satisfação dos direitos da infância e da adolescência. ${ }^{196}$ No presente caso, a Corte não considera que o Estado adotou todas as medidas positivas para garantir os direitos das meninas desaparecidas, por não ter assegurado que as meninas fossem encontradas com maior brevidade, mesmo sabendo de contexto específico em que ocorriam esses desaparecimentos. Portanto, a Corte entende que o Estado violou os direitos da criança consagrados no artigo 19 da Convenção Americana, em relação com os artigos 1.1 e $2^{\circ}$ do mesmo documento, em prejuízo das vítimas Laura Berenice Ramos e Esmeralda Herrera Monreal. ${ }^{197}$

\subsubsection{Análise da sentença do caso González e Outras ("Campo}

\section{Algodonero") Vs. México}

O caso Campo Algodonero Vs. México, como apresentado no ponto 1.2.2, têm a sua primeira grande importância atribuída ao fato de ter sido o primeiro caso em que a Corte Interamericana de Direitos Humanos tratou exaustivamente sobre os direitos das mulheres e das questões relacionadas à violência e a discriminação de gênero, principalmente no que se refere à obrigação de devida diligência para prevenir e investigar atos de violência contra a mulher, utilizando a Convenção de Belém do Pará como marco

\footnotetext{
${ }^{195}$ CORTE IDH, Caso González y Otras ("Campo Algodonero") vs. México. Sentença de 16 de novembro de 2009. para. 298.

${ }^{196}$ CORTE IDH, Caso González y Otras (“Campo Algodonero”) vs. México. Sentença de 16 de novembro de 2009. para. 396.

${ }^{197}$ CORTE IDH, Caso González y Otras ("Campo Algodonero") vs. México. Sentença de 16 de novembro de 2009. para. 402.
} 
normativo para interpretação destas violações. ${ }^{198}$ Embora o caso Penal Miguel Castro Castro Vs. Peru tenha grande relevância por ter sido o primeiro caso em que a Corte aplicou a Convenção Belém do Pará para interpretação das violações dos direitos das mulheres, as violações de gênero no caso Miguel Castro Castro, representaram uma questão secundária diante de outras violações de direitos humanos que ensejaram a responsabilização do estado peruano.

O segundo e principal aspecto de grande relevância no caso Campo Algodonero é que, além de ter tratado exclusivamente das questões de gênero, o caso analisou as violações dos direitos das mulheres não somente a partir de uma perspectiva jurídica, mas também através de uma perspectiva sócio-cultural. A atividade da Corte IDH, portanto, não só se ateve à atividade de interpretar os fatos diretos e específicos das três vítimas à luz dos artigos violados da Convenção Americana, mas também buscou demonstrar o contexto geral discriminatório, como marco que ensejou a ocorrência de atos de violência contra a mulher neste caso e que impediu que os Estados agissem com devida diligência para prevenir e investigar as violações elencadas. A Corte IDH ressaltou que os assassinatos das jovens ocorreram em um contexto específico caracterizado por um padrão de discriminação existente na Ciudad Juárez que legitima os atos de violência perpetrados e que puderam caracterizá-los como atos de violência baseados em gênero, acolhendo a denominação de feminicídio dada pelos representantes. A Corte reconheceu que estes estereótipos de gênero socialmente dominantes e persistentes se refletiram de forma expressa na conduta das autoridades e tiveram papel na inércia do Estado para cumprir com a sua obrigação de garantia em relação aos direitos das mulheres violados no presente caso.

O terceiro aspecto importante foi o reconhecimento da vulnerabilidade das mulheres vítimas do caso, que tiveram que enfrentar uma dupla discriminação, em razão do gênero e da classe social. Todas as

\footnotetext{
${ }^{198}$ CIDH, Relatório Anual, Capítulo II, 2009. para. 56.
} 
vítimas eram de origem humilde - trabalhadoras ou estudantes -, o que imporia, segundo a Corte, uma responsabilidade estatal ilimitada frente qualquer fato ilícito contra elas. Nesse sentido, a Corte confirmou o seu entendimento, já evidenciado no caso Miguel Penal Castro Castro Vs. Peru, em que a Corte apontou o tratamento especial requerido pelas mulheres presas, grávidas ou em período de lactância, de que há inúmeras interseccinalidades que geram outras formas de discriminação contra a mulher, além daquelas formas baseadas em gênero. No caso das meninas Laura Berenice Ramos e Esmeralda Herrera Monreal, o fator idade também foi levado em consideração pela Corte. A Corte afirmou o seu entendimento no sentido de que as crianças merecem um tratamento especial em razão da sua menor idade e conseqüente vulnerabilidade, que corresponde a deveres específicos por parte da família, da sociedade e do Estado para satisfação dos direitos da infância e da adolescência.

\subsection{A jurisprudência da Corte Interamericana de Direitos Humanos e o reconhecimento da violência baseada em gênero}

Como já apresentado na introdução do capítulo, ainda não são muitos os casos em que a Corte IDH reconheceu as violações de direitos das mulheres a partir de uma perspectiva de gênero. No entanto, a partir da análise da sua jurisprudência podemos identificar uma grande evolução no reconhecimento e na interpretação das violações dos direitos das mulheres, principalmente nos casos de violência.

Esta evolução pode ser claramente observada através da análise do caso María Elena Loayza Tamayo Vs. Peru ${ }^{199}$, julgado em 1998, em que a Corte entendeu que não havia provas suficientes para que o Estado fosse responsabilizado pelo crime de estupro cometido contra a vítima por seus agentes, após ter declinado de examinar certas questões e provas

\footnotetext{
${ }^{199}$ CORTE IDH, Caso Loayza Tamayo vs. Peru. Sentença de 27 de novembro de 1998. para. 58.
} 
apresentadas pela Comissão, em face dos outros casos mais recentes julgados pela Corte IDH.

No caso Penal Miguel Castro Castro vs. Peru ${ }^{200}$, julgado em 2006, a Corte IDH, além de analisar as diversas formas de violência baseada em gênero sofridas pelas mulheres que se encontravam no presídio ${ }^{201}$, principalmente no reconhecimento e no alcance da interpretação da violência sexual sofrida ${ }^{202}$, que também foi caracterizada pela Corte IDH como ato de tortura ${ }^{203}$, também reconheceu a vulnerabilidade das mulheres gestantes, mães e das presidiárias em relação aos atos de violência perpetrados ${ }^{204}$ pelos agentes do presídio.

No caso Campo Algodonero, a Corte IDH não só adotou a Convenção de Belém do Pará para reconhecer e interpretar a violência sexual sofrida pelas vítimas, como analisou detalhadamente o contexto discriminatório de gênero responsável pela ocorrência destas práticas e pela ausência de devida diligência na prevenção e investigação destes crimes,

${ }^{200}$ CORTE IDH, Caso Penal Miguel Castro Castro vs. Peru. Sentença de 25 de novembro de 2006.

${ }^{201}$ A Corte Interamericana reconheceu que as mulheres foram atingidas de forma especialmente violenta e gravosa pelo fato de serem mulheres, possibilitando a caracterização da violência empregada como uma violência baseada em gênero. A partir da análise dos fatos, a Corte ressaltou os danos físicos e psicológicos adicionais que as mulheres sofreram ao serem transferidas de um pavilhão para o outro, principalmente as mulheres grávidas. Além disso, as mulheres foram vitimas de maus tratos físicos e psicológicos dentro do presídio e foram desnudadas pelos agentes durante a transferência para o hospital, permanecendo nessas condições durante vários dias. A Corte também considerou relevantes as condições precárias de higiene a que as mulheres presas foram submetidas, principalmente durante o período menstrual. CORTE IDH, Caso Penal Miguel Castro Castro vs. Peru. Sentença de 25 de novembro de 2006. para. 306.

${ }^{202}$ A Corte entendeu que as mulheres também foram vítimas de violência sexual, em razão de terem sido constantemente observadas por homens em condições de nudez. O fato das mulheres permanecerem nuas no hospital, vigiadas por homens armados, no estado precário de saúde em que se encontravam, constituiu violência sexual nos termos do exposto acima. Seguindo a linha da jurisprudência internacional e levando em conta o exposto na Convenção Belém do Pará, a Corte Interamericana considerou que a violência sexual se configura com as ações de natureza sexual que se cometem contra uma pessoa sem o seu consentimento, que além de incluir a invasão física de um corpo humano, pode incluir atos que não envolvam penetração ou contato físico algum, como ocorreu no presente caso, em que algumas das mulheres foram submetidas à inspeção vaginal. $\mathrm{O}$ fato das mulheres permanecerem nuas no hospital, vigiadas por homens armados, no estado precário de saúde em que se encontravam, constituiu violência sexual nos termos do exposto. CORTE IDH, Caso Penal Miguel Castro Castro vs. Peru. Sentença de 25 de novembro de 2006. para. 302-308; 310-311.

${ }^{203}$ A Corte reconheceu que a inspeção vaginal a que foi submetida um detenta, por seus efeitos caracterizou um ato de tortura. CORTE IDH, Caso Penal Miguel Castro Castro vs. Peru. Sentença de 25 de novembro de 2006. para. 312.

${ }^{204}$ CORTE IDH, Caso Penal Miguel Castro Castro vs. Peru. Sentença de 25 de novembro de 2006. para. 303. 
concluindo que as condições discriminatórias da ordem social se convertem não só como causa, senão como conseqüência da violência baseada em gênero, criando danos que se perpetuam, enquanto os atos não sejam efetivamente punidos e reparados.

Por último, cabe analisarmos brevemente os dois mais recentes julgados da Corte Interamericana acerca do tema, os casos Rosendo Cantú e Outra Vs. México ${ }^{205}$ e Fernández Ortega e Outros Vs. México ${ }^{206}$. A demanda nos dois casos se refere, sem considerações às especificidades de cada caso, à responsabilidade internacional do Estado pela violação e tortura em prejuízo das vítimas indígenas, que foram violentadas sexualmente por oficiais militares; pela falta de devida diligência nas investigações e sanções dos responsáveis; pela falta de reparação adequada em favor das vítimas e de seus familiares; e pela utilização de foro militar para investigação e ajuizamento das violações de direitos humanos; e pelas dificuldades que as pessoas indígenas, em particular as mulheres, encontram para terem acesso à justiça. Nos dois casos, a Corte IDH reconhece a vulnerabilidade das mulheres indígenas em relação aos atos de violência, principalmente nos casos de violência sexual ${ }^{207}$, e menciona as dificuldades particulares enfrentadas pelas mulheres indígenas para que

\footnotetext{
${ }^{205}$ CORTE IDH, Caso Fernández Ortega y Otros vs. México. Sentença de 30 de agosto de 2010. ${ }^{206}$ CORTE IDH, Caso Rosendo Cantu y Otra vs. México. Sentença de 31 de agosto de 2010.

${ }^{207}$ Nos casos Rosendo Cantú e Outra vs. México e Fernández Ortega e Outros vs. México, a Corte Interamericana confirma a sua evolução na interpretação dos casos de violência sexual. Conforme já enunciado no caso Penal Miguel Castro Castro vs. Peru, a Corte confirmou o seu entendimento de que a violência sexual se configura nas ações de natureza sexual que se cometem contra uma pessoa sem seu consentimento, que embora compreenda a invasão física de um corpo humano, pode incluir atos que não envolvam penetração alguma ou contato físico algum. Além disso, como também enunciado no caso Penal Miguel Castro Castro vs. Peru nos dois casos a Corte compreendeu que os atos de violência sexual podem ser classificados como atos de tortura, desde que presentes os elementos caracterizadores da prática, como ocorreu nos dois casos. Por último, a Corte considerou a violação do artigo 11 da Convenção, ao entender que a violência sexual contra as vítimas violou valores e aspectos essenciais da sua vida privada, através da intromissão na sua vida sexual, anulando o seu direito de tomar livremente as decisões a respeito de com quem deseja ter relações sexuais, perdendo de forma completa o controle sobre as suas decisões mais pessoais e íntimas sobre as funções corporais básicas. O artigo 11 da Convenção Americana, embora intitulado de "Proteção da Honra e da Dignidade", seu conteúdo inclui entre outros, a proteção da vida privada. Ver CORTE IDH, Caso Fernández Ortega y Otros vs. México. Sentença de 30 de agosto de 2010. para. 119 e 129 e Caso Rosendo Cantu y Otra vs. México. Sentença de 31 de agosto de 2010. para. 119-121.
} 
obtenham o efetivo acesso à justiça. Além disso, a Corte IDH interpretou a violência sexual praticada como um ato de tortura e considerou que estes atos violaram aspectos essenciais da vida privada das vítimas, como o direitos de tomar suas decisões sobre a sua vida sexual. O dois casos corroboram a evolução da Corte Interamericana no reconhecimento dos direitos das mulheres, a partir de uma perspectiva de gênero, que tem como marco principal o caso Campo Algodonero, principalmente, no que se refere ao direito a uma vida livre de violência e as dificuldades enfrentadas pelas mulheres vítimas de violência para que obtenham o acesso efetivo à justiça, além de reconhecer a maneira particular como as mulheres indígenas são afetadas quando vítimas de violência. 


\section{Conclusão}

O presente trabalhou foi elaborado, portanto, a partir da premissa adotada pelo Sistema Interamericano de Direitos Humanos de que o acesso à justiça de jure e de facto é essencial para a erradicação do problema da violência contra a mulher e é precondição necessária para que os Estados cumpram com a sua obrigação internacional de agir com devida diligência para prevenir, investigar, processar e reparar os atos de violência contra a mulher. Este princípio foi concretizado no âmbito interamericano, através da aprovação da Convenção Interamericana para Prevenir, Punir e Erradicar a Violência contra a Mulher (Convenção de Belém do Pará), que reconheceu o direito das mulheres a uma vida livre de violência e ressaltou a obrigação de garantia dos Estados de agir com devida diligência em face dos atos de violência baseada em gênero. No entanto, o estudo realizado demonstra que são evidentes os obstáculos enfrentados pelas mulheres vítimas de violência para que tenham o acesso efetivo aos mecanismos judiciais disponíveis.

As dificuldades de acesso à justiça nos casos de violência submetem as mulheres a uma nova situação de discriminação e faz com que essas práticas permaneçam impunes e se perpetuem em sociedade. Nesse sentido, faz-se necessária a atuação estatal para o enfretamento dessa violação a partir da concepção de que a violência de gênero é uma violência estrutural, que perpassa os mais variados setores sociais e atinge os vários perfis de mulheres. $\mathrm{O}$ direito das mulheres a uma vida livre de violência possui um amplo alcance e acarreta o impedimento ao gozo de outros direitos fundamentais como o direito à vida, à liberdade e à integridade pessoal, o que evidencia a importância dos Estados-Partes tratarem esse grave problema como um desafio prioritário a ser superado.

O Sistema Interamericano tem demonstrado a sua evolução acerca do reconhecimento e da interpretação das violações dos direitos das mulheres, principalmente, no que se refere à violência baseada em gênero. $\mathrm{O}$ comprometimento da Comissão Interamericana de Direitos Humanos e da 
sua Relatoria Especial sobre os Direitos da Mulher com o tema se revela pela dedicação ao estudo do acesso à justiça para vítimas de violência, através da produção de diversos relatórios temáticos e do desenvolvimento de padrões específicos para que os Estados possam cumprir com a sua obrigação de garantia, assegurando o direito das mulheres a uma vida livre de violência. $\mathrm{O}$ reconhecimento das violações de direitos com base no gênero se revela ainda de forma mais contundente através da ampla aplicação da Convenção de Belém do Pará pela Comissão para interpretar as supostas violações dos direitos das mulheres pelos Estados-Partes e para declarar que os Estados têm a obrigação de agir com devida diligência diante dos crimes de violência contra a mulher.

Esta evolução pôde ser confirmada através do estudo do caso González e Outras ("Campo Algodonero”) Vs. México, que confirmou o desenvolvimento da Corte Interamericana na apreciação dos casos de violação com base no gênero. Além de ter sido o primeiro caso em que a Corte tratou exaustivamente das questões de gênero, utilizando a Convenção de Belém do Pará como marco normativo para interpretação das violações dos direitos das mulheres, a Corte ampliou a sua margem de apreciação para além da análise jurídica dos fatos, vinculando a violação dos direitos das três vítimas pela violência sofrida e pelas deficiências na prevenção e das investigações dos crimes ao padrão estrutural de discriminação de gênero existente na região. Dessa forma, a Corte também amplia a sua margem de proteção aos direitos das mulheres, à medida que analisa não só as violações seus aos direitos, mas o contexto que legitima estes atos e que permite que eles permaneçam impunes e não reparados.

Neste sentido, podemos concluir que o acesso efetivo à justiça permanece como um dos principais obstáculos a serem enfrentados pelas mulheres vítimas de violência. A ausência de devida diligência na atuação dos Estados está intimamente relacionada com os mesmos padrões discriminatórios responsáveis pela ocorrência dos atos de violência, o que dificulta que esta obrigação seja efetivamente cumprida pelos Estados- 
Partes. Apesar de serem ainda inúmeras as dificuldades para que esse desafio seja superado, o Sistema Interamericano de Direitos Humanos tem atuado prioritariamente no desenvolvimento de padrões de acesso à justiça que devem ser cumpridos pelos Estados para que os atos de violência contra a mulher sejam prevenidos, investigados, punidos e reparados e para que seja garantido o direito das mulheres a uma vida livre de violência. $\mathrm{O}$ desenvolvimento destes padrões vem acompanhado da evolução do Sistema Interamericano na interpretação das violações dos direitos das mulheres, como visto através da análise do caso Campo Algodonero e da jurisprudência da Corte IDH, representando uma importante ampliação da garantia dos seus direitos no âmbito interamericano. 


\section{Referências Bibliográficas}

ABI-MERSHED, Elizabeth, Due Diligence and the Fight against Gender Based Violence in the Inter- American System. IN: BENNINGER-BUDEL, Carin (Org). Due Diligence and its Application to Protect Women from Violence. Netherlands: Martinus Nijhoff Publishers, 2008.

CLADEM, Sistematização de Experiências em Litígio Internacional, outubro de 2009.

PIOVESAN, Flávia. Direitos Humanos e o Direito Constitucional Internacional. $9^{\mathrm{a}}$ ed. São Paulo: Saraiva, 2008.

. Temas de Direitos Humanos. $3^{\mathrm{a}}$ Edição. São Paulo: Saraiva, 2009.

TRINDADE, Antônio A. Tratado de direito Internacional dos Direitos Humanos. Vol. III. $1^{\text {a }}$ ed. Porto Alegre: Sergio Antonio Fabris Editor, 2003.

Documentos Eletrônicos

COMISSÃO INTERAMERICANA DE DIREITOS HUMANOS. $O$ que é a CIDH. Disponível em http://www.cidh.oas.org/que.port.htm. Acesso em: 16.10.10

\section{Comissão Interamericana de Direitos Humanos}

COMISSÃO INTERAMERICANA DE DIREITOS HUMANOS, Mérito, № 5/96, Raquel Martín de Mejía (Peru). Março 1, 1996.

Solução Amistosa, caso 12.041, M.M (Peru). Março 17, 2000. 
- Mérito, $\mathrm{N}^{\mathrm{o}}$ 4/01, Maria Eugenia Morales de Sierra (Guatemala). Janeiro 19, 2001.

- Mérito, $\mathrm{N}^{\mathrm{o}}$ 4/01, Maria Eugenia Morales de Sierra (Guatemala). Janeiro 19, 2001.

. Mérito, No 54/01, Maria da Penha Fernandes (Brasil). Abril $16,2001$.

. Solução Amistosa, No 73/01, M.Z (Bolívia). Outubro 10, 2001.

- Solução Amistosa, № 21/07, Paulina Del Carmen Ramírez Jacinto (México). Março 9, 2007.

Relatoria Especial sobre os Direitos da Mulher. Relatório sobre a Situação dos Direitos Humanos das Mulheres nas Américas, OEA/Ser.L/V/II.100Doc.17, 13 outubro, 1998.

Relatoria Especial sobre os Direitos da Mulher. Relatório sobre Acesso à Justiça para Mulheres Vítimas de Violência nas Américas, OEA/Ser.L/V//II, 20 Janeiro, 2007.

Relatoria Especial sobre os Direitos da Mulher. Relatório sobre Violência e Discriminação contra a Mulher no Conflito Armado na Colômbia ,OEA OEA/Ser.L/V/II, 18 de outubro, 2006.

Relatoria Especial sobre os Direitos da Mulher. Relatório sobre os Direitos das Mulheres no Chile: Igualdade na Família, Trabalho e na Esfera Política, OEA/Ser.L/V/II.134, 27 Março, 2009 
. Relatoria Especial sobre os Direitos da Mulher. Relatório sobre a Situação dos Direitos da Mulher na Cidade de Juárez, México: o Direito a não ser objeto de Violência e Discriminação, OEA/Ser.L/V/II.117, 7 Março, 2003.

. Relatoria Especial sobre os Direitos da Mulher. Relatório sobre

o Direito das Mulheres no Haiti a um Vida Livre de Violência e Discriminação, OEA/Ser.L/V/II, 10 Março, 2009.

Access to Justice as a Guarantee of Economic, Social and Cultural Rights. - A Review of the Standards Adopted by the Inter-American System of Human Rights, OEA/Ser.L/V/II.129, Doc. 4 , 7 September 2007.

\section{Jurisprudência}

\section{Corte Interamericana de Direitos Humanos}

CORTE INTERAMERICANA DE DIREITOS HUMANOS. Velásquez Rodríguez vs Honduras. Sentença de 29 de julho de 1987.

Loayza Tamayo vs. Peru. Sentença de 27 de novembro de 1998.

. “Massacre Mapiripán” vs. Colombia. Sentença de 15 de novembro de 2005

Massacre de Pueblo Bello vs. Colombia. Sentença de 31 de janeiro de 2006. 
Penal Miguel Castro Castro vs. Peru. Sentença de 25 de novembro de 2006.

. Caso González y Otras ("Campo Algodonero”) vs. México.

Sentença de 16 de novembro de 2009.

- Fernández Ortega y Otros vs. México. Sentença de 30 de agosto de 2010 .

Rosendo Cantu y Otra vs. México. Sentença de 31 de agosto de 2010.

\section{Corte Européia de Direitos Humanos}

CORTE EUROPÉIA DE DIREITOS HUMANOS. Osman vs. Reino Unido, Sentença de 28 de outubro de 1998.

. M.C. v. Bulgaria, Sentença de 04 de março de 2004.

. Caso Opuz v. Turkey, Sentença de 09 de junho de 2009 